\title{
Grizzly Bear Population and Habitat Status in Kananaskis Country, Alberta
}

\section{A Report to the \\ Department of Environmental Protection, Natural Resources Service, Alberta}




\section{Preface}

This report was prepared for Alberta Environmental Protection by the East Slopes Grizzly Bear Project to provide background information for the Kananaskis Country Recreation Development Policy Review. The report contains professional comment and advice but does not reflect the policy of the Government of Alberta. 


\title{
GRIZZLY BEAR POPULATION AND HABITAT STATUS \\ IN KANANASKIS COUNTRY, ALBERTA:
}

\section{A Report to the Department of Environmental Protection, Natural Resources Service, Alberta}

\author{
Authors of this document (in alphabetical order): \\ Bryon Benn ${ }^{1}$ \\ Steve Donelon ${ }^{2}$ \\ Michael Gibeau ${ }^{3}$ \\ Steve Herrero ${ }^{1}$ \\ John Kansas ${ }^{3}$ \\ Editor \\ Guy Greenaway
}

May, 1998

\section{Suggested citation:}

Eastern Slopes Grizzly Bear Project. 1998. Grizzly Bear Population and Habitat Status in Kananaskis Country, Alberta: A Report to the Department of Environmental Protection, Natural Resources Service, Alberta. Prepared by the Eastern Slopes Grizzly Bear Project, University of Calgary, Calgary, Alberta.

\footnotetext{
${ }^{1}$ Faculty of Environmental Design, University of Calgary. 2500 University Drive N.W., Calgary, Alberta, Canada. T2N $1 \mathrm{~N} 4$.

${ }^{2}$ Department of Environmental Protection, Natural Resources Service, Bow Region. Suite 201, 800 Railway Avenue, Canmore, Alberta, Canada. T1W 1T1 ${ }^{3}$ Committee on Resources and the Environment, University of Calgary. 2500 University Drive N.W., Calgary, Alberta,
Canada. T2N 1N4.
} 
Digitized by the Internet Archive in 2017 with funding from University of Alberta Libraries 


\section{TABLE OF CONTENTS}

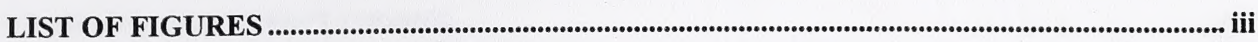

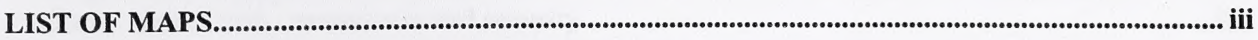

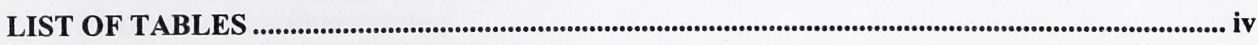

EXECUTIVE SUMMARY

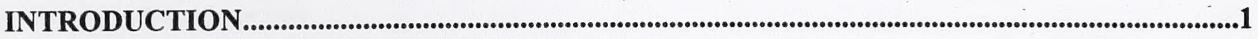

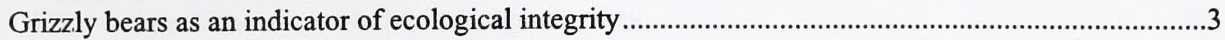

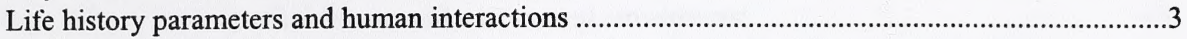

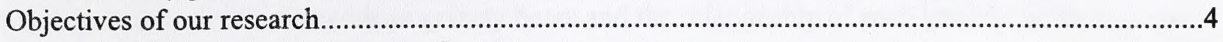

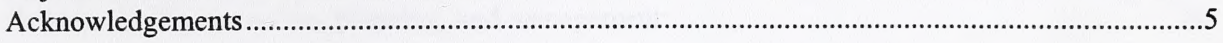

POPULATION OVERVIEW ...............................................................................................................6

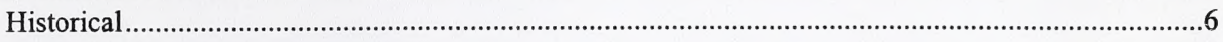

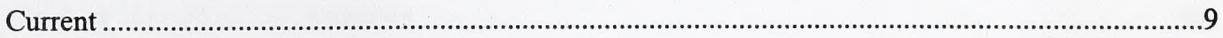

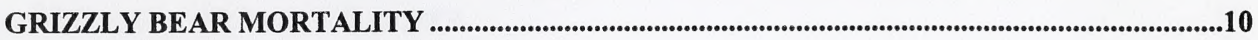

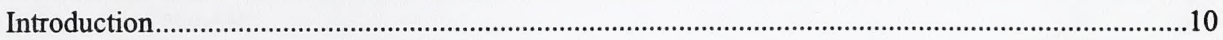

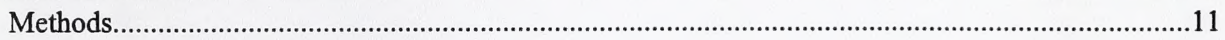

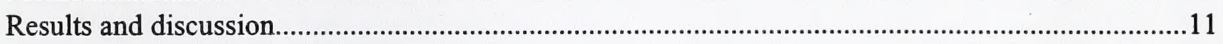

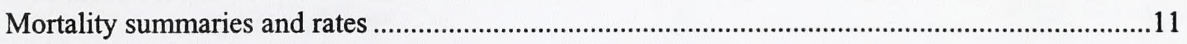

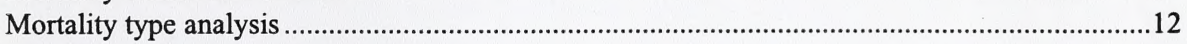

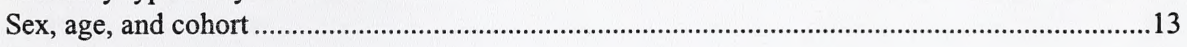

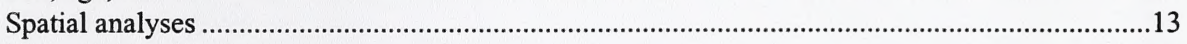

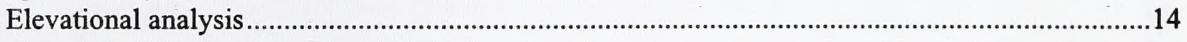

ECOLOGICAL DESCRIPTION OF KANANASKIS COUNTRY......................................................16

Vegetation communities of Kananaskis Country .................................................................................16

Bear Management Unit (BMUs) of Kananaskis Country ...........................................................17

WILDLIFE MOVEMENT AREAS OF KANANASKIS COUNTRY ...............................................17

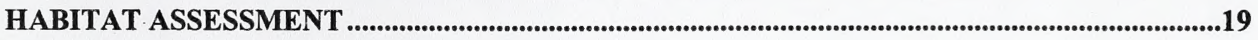

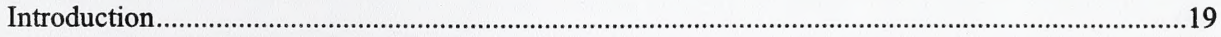

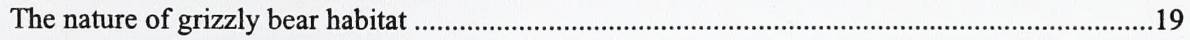

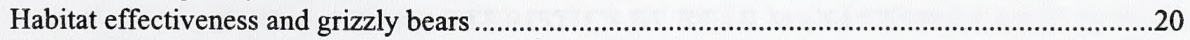

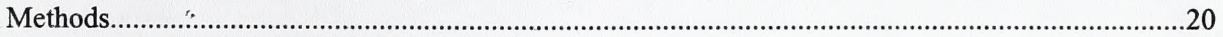

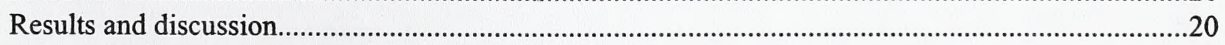

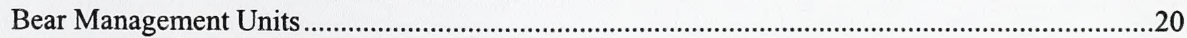

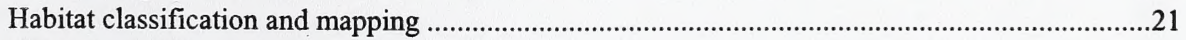

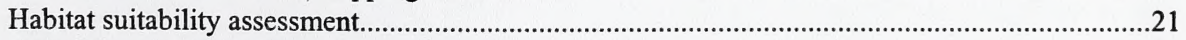

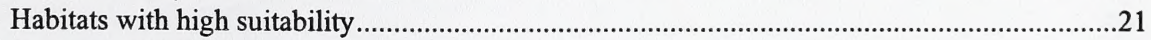

Seasonal distribution and abundance of high suitability habitat.............................................2

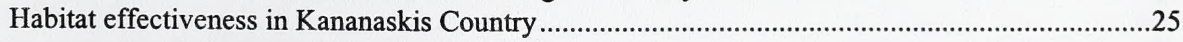

GRIZZLY BEAR SECURITY AREAS IN KANANASKIS COUNTRY..........................................29

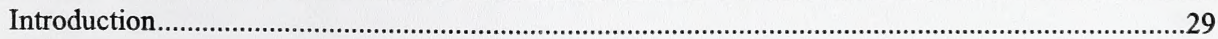

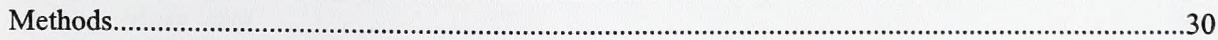

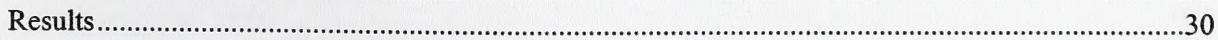





\section{SUMMARY AND CONCLUSIONS.}

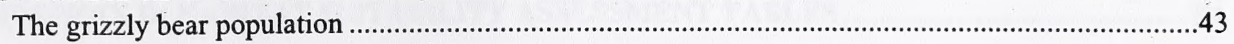

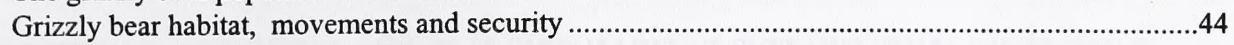

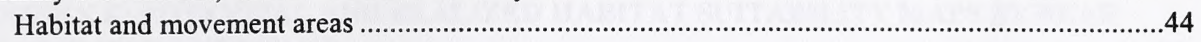

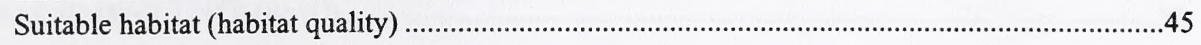

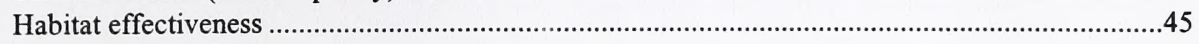

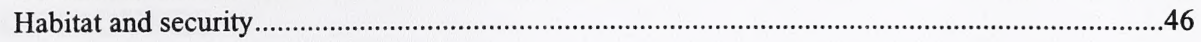

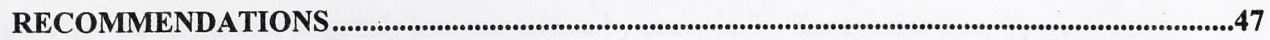

1. Regarding grizzly bear mortality and reproduction: ..................................................................47

2. Regarding grizzly bear habitat, security areas, and movements: ...............................................48

3. Regarding scientific research on grizzly bears and the relationship of such knowledge to regional

land use policy formation, planning, and management: ..............................................................49

LITERATURE CITED ..............................................................................................................................................50

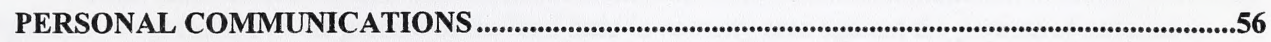

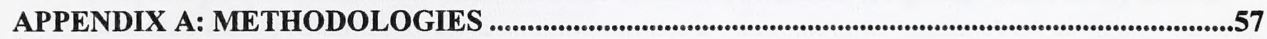

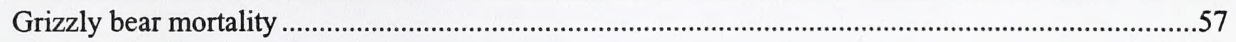

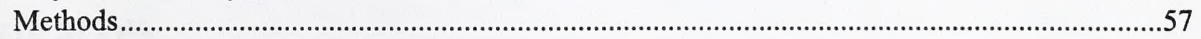

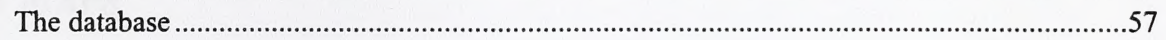

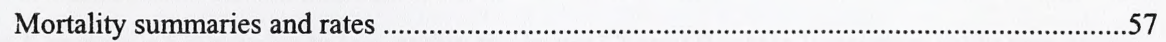

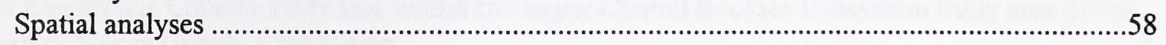

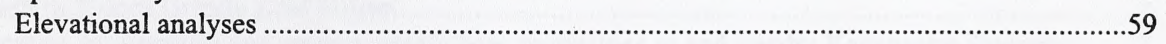

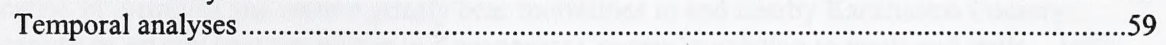

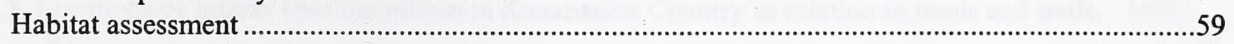

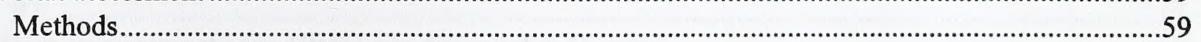

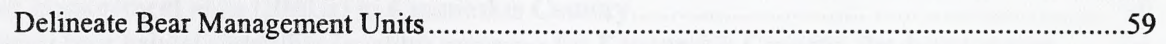

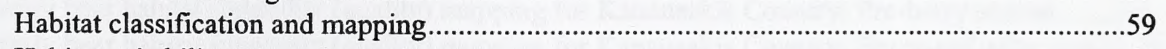

Habitat suitability assessment.............................................................................................61

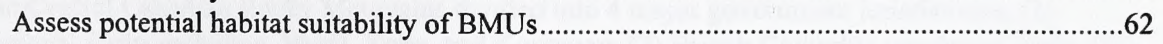

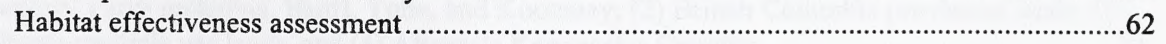

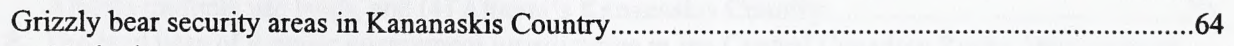

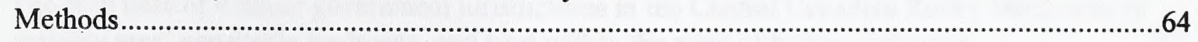

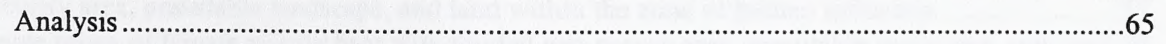

APPENDIX B: ECOLOGICAL CHARACTERISTICS BY BEAR MANAGEMENT UNIT (BMU)67

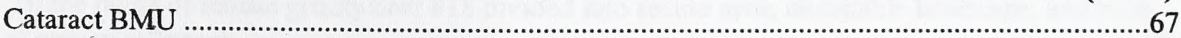

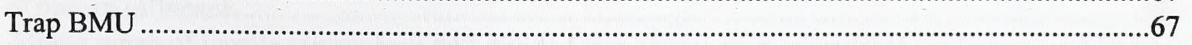

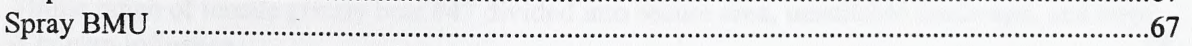

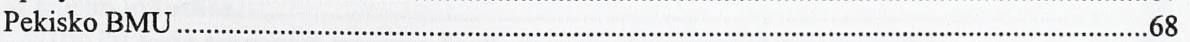

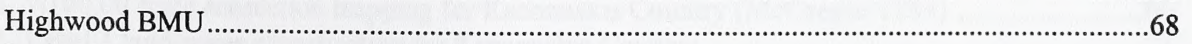

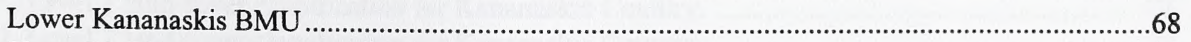

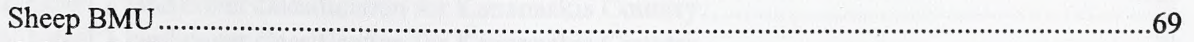

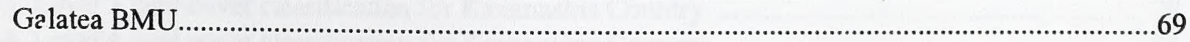

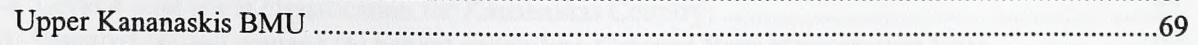

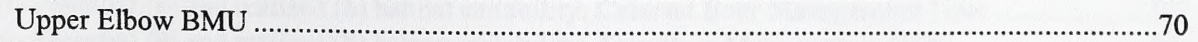

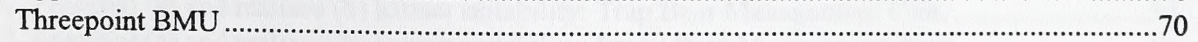

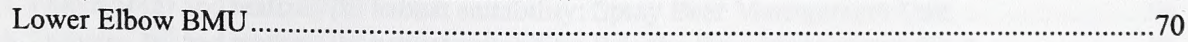

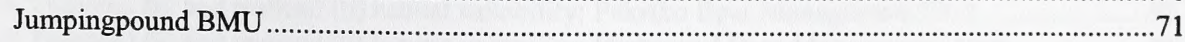





\section{APPENDIX E: POTENTIAL AND REALIZED HABITAT SUITABILITY MAPS BY BEAR MANAGEMENT UNIT (BMU).}

\section{LIST OF FIGURES}

Figure 1. Annual number of grizzly bear mortalities by cause in the Kananaskis Country study area, 1972-97 ( $n=32)$.

Figure 2. Frequency of grizzly bear mortalities by elevation class, 1972-97 $(n=32)$, and elevations at arbitrary landmarks along a sample of valleys in the Kananaskis Country study area.

Figure 3. Percent of the land base in security area, unsuitable landscape, and land within the zone of human influence for 4 major government jurisdictions in the Central Canadian Rocky Mountains.32

Figure 4. Time series analysis of grizzly bear security areas for Kananaskis Country and Banff National Park.

Figure 5. Regressions of the percent of the land base in security area against the percent of unsuitable land, and percent of the land within the zone of human influence for grizzly bears in the Central Canadian Rocky Mountains.

\section{LIST OF MAPS}

Map 1. The Kananaskis Country study area within the larger Central Rockies Ecosystem study area of the Eastern Slopes Grizzly Bear Project.

Map 2. Location of historical and current grizzly bear mortalities in and nearby Kananaskis Country........7

Map 3. Locations of grizzly bear mortalities in Kananaskis Country in relation to roads and trails, 197297.

Map 4. Bear management units (BMUs) in Kananaskis Country........................................................18

Map 5. Grizzly bear habitat suitability (quality) mapping for Kananaskis Country: Pre-berry season. .......23

Map 6. Grizzly bear habitat suitability (quality) mapping for Kananaskis Country: Berry-and-after season.24

Map 7. The Central Canadian Rocky Mountains divided into 4 major government jurisdictions: (1) National Parks including, Banff, Yoho, and Kootenay; (2) British Columbia provincial lands, (3) Alberta multiple use lands, and (4) Alberta's Kananaskis Country.

Map 8. The land base of 4 major government jurisdictions in the Central Canadian Rocky Mountains in security area, unsuitable landscape, and land within the zone of human influence.

Map 9. Home range of female grizzly bear \#26 divided into secure area, unsuitable landscape, and zone of human influence.

Map 10. Home range of female grizzly bear \#18 divided into secure area, unsuitable landscape, and zone of human influence

Map 11. Home range of female grizzly bear $\# 47$ divided into secure area, unsuitable landscape, and zone of human influence

Map A-1. 1:100,00 scale ecosection mapping for Kananaskis Country (McGregor 1984)........................60

Map C-1. Level 1 land cover classification for Kananaskis Country.........................................................73

Map C-2. Level 2 land cover classification for Kananaskis Country.......................................................75

Map C-3. Level 3 land cover classification for Kananaskis Country. ..........................................................78

Map C-4. Level 4 land cover classification for Kananaskis Country. ......................................................83

Map E-1. Potential (a) and realized (b) habitat suitability: Cataract Bear Management Unit. ......................92

Map E-2. Potential (a) and realized (b) habitat suitability: Trap Bear Management Unit...........................93

Map E-3. Potential (a) and realized (b) habitat suitability: Spray Bear Management Unit. .........................94

Map E-4. Potential (a) and realized (b) habitat suitability: Pekisko Bear Management Unit.......................95

Map E-5. Potential (a) and realized (b) habitat suitability: Highwood Bear Management Unit...................96 
Map E-6. Potential (a) and realized (b) habitat suitability: Lower Kananaskis Bear Management Unit......97

Map E-7. Potential (a) and realized (b) habitat suitability: Sheep Bear Management Unit.........................98

Map E-8. Potential (a) and realized (b) habitat suitability: Galatea Bear Management Unit. ....................99

Map E-9. Potential (a) and realized (b) habitat suitability: Upper Kananaskis Bear Management Unit. ...100

Map E-10. Potential (a) and realized (b) habitat suitability: Upper Elbow Bear Management Unit..........101

Map E-11. Potential (a) and realized (b) habitat suitability: Threepoint Bear Management Unit..............102

Map E-12. Potential (a) and realized (b) habitat suitability: Jumpingpound Bear Management Unit........103

Map E-13. Potential (a) and realized (b) habitat suitability: Lower Elbow Bear Management Unit..........104

\section{LIST OF TABLES}

Table 1. Human-caused grizzly bear mortalities by cause of death in the Kananaskis Country study area for the 2 analysis periods, $1972-80$ and 1981-97.

Table 2. Human-caused grizzly bear mortalities by class, for the analysis periods 1972-80 and 1981-97. 13

Table 3. Percent occurrence of 10 classes of habitat suitability for pre-berry season by bear management unit (BMU).

Table 4. Percent occurrence of 10 classes of habitat suitability for berry-and-after season by bear management unit (BMU). . .27

Table 5. Habitat effectiveness values for 13 bear management units (BMUs) in Kananaskis Country........25

Table 6. Percent of the land base in security area, unsuitable landscape, and land within the zone of human influence for 20 adult female grizzly bears in the Central Canadian Rocky Mountains.................36

Table C-1. Area analyses for Level 1 land cover classification for Kananaskis Country............................74

Table C-2. Area analyses for Level 2 land cover classification for Kananaskis Country..............................76

Table C-3. Area analyses for Level 3 land cover classification for Kananaskis Country............................79

Table D-1. Frequency distribution of Level 1 sampling plots by Level 4 habitat map unit. .......................85

Table D-2. Habitat suitability index (HSI) values for ungulate, ant and plant food sub-models.................86

Table D-3. Eastern slopes grizzly bear habitat suitability model output......................................................8 



\section{EXECUTIVE SUMMARY}

Alberta's grizzly bear population has decreased from a pre-European time estimate of 6000 to a current estimate of about 800 . Grizzly bears are nationally classified as vulnerable, and within Alberta as a species at risk (blue listed). Responding to concerns for the status and future of grizzly bears in Kananaskis Country, Banff National Park and surround, the Eastern Slopes Grizzly Bear Project began in 1994. Its primary mandate is to provide scientific data and understanding regarding the grizzly bear population and its habitat. Because this is one of the most developed and used places in North America where grizzly bears survive, particular emphasis is being placed on understanding the cumulative effects on grizzly bears of developments and people's activities throughout the region. The Project is funded and guided by a Steering Committee which has representatives from most of the major stakeholder groups active in the Project area. Stakeholders include representatives from the federal and provincial governments, businesses, university and environmental groups. Four years of research have been completed, supported by an average annual budget of $\$ 350,000$. Research has been carried out primarily as a series of Master's and Ph.D. research projects at the University of Calgary with cooperation from involved agencies, institutions and individuals.

This report and interpretation of the Project's research focuses on grizzly bears in Kananaskis Country and surround. It has been prepared by the Eastern Slopes Grizzly Bear Project team at the request of Alberta Environmental Protection, Natural Resources Service as part of their Kananaskis Country Recreation Policy Review. Our report on grizzly bear population and habitat status is based on preliminary interpretation of ongoing research for which we will complete stage one in the year 2000. Many biological and behavioural characteristics of grizzly bears require long term study for acceptable levels of scientific understanding.

As part of our research we have trapped grizzly bears in the Bow River Watershed and have maintained radio-transmitters on approximately 25 grizzly bears a year. We regularly monitored these animals from air and ground to determine home ranges, movements, survivorship, habitat use and relationships with people's developments and activities. In parallel with radio-telemetry efforts we have classified habitat and its use by employing remote sensing, field analyses of landscape units, and mapping using Geographical Information System (GIS) technology. Some of our research presents the results of models developed by ourselves, and in the United States, to understand the effects of human activities and developments on grizzly bears. We have developed a habitat suitability model to represent the food value or quality (suitability) of a given area. Two models from the United States, the Cumulative Effects Model and Security Area Analysis, help us to understand human influences on habitat use and movements. The assumptions in these models are explicit and are based on interpretation of research results, however they only represent our best current understanding. The results of such modelling are an essential part of the science of trying to understand grizzly bear populations and habitat. They are not absolute representations of reality. They do summarize our current understanding and allow us and others to question, test and 

improve assumptions. However, specific model assumptions such as the influence of different levels of human use on grizzly bear habitat use, and the extent of influence of human use as expressed by buffers (see pp. xii and 63) will continue to be refined.

\section{The grizzly bear population}

(see Introduction, Population overview and Grizzly bear mortality, pp. 1-15; and Maps 2 and 3 , pp. 7 and 15 )

The population and habitat status of grizzly bears in Kananaskis Country and the surrounding ecosystem can be viewed as an indicator of regional ecological integrity. This is because grizzly bears are a species with little resiliency. Because of large home ranges and movements, low population densities, low total population numbers, a very low reproductive rate and occasional direct conflict with people, grizzly bears are easy to remove or lose from any area.

Historically grizzly bears were distributed throughout what is today Kananaskis Country. Now they are apparently significantly reduced in density in eastern portions of Kananaskis Country, and somewhat reduced in density in western portions.

Today there are few grizzly bears in Kananaskis Country. Although the science behind current grizzly bear population estimates for Kananaskis Country is not exact, population estimates range from 50 to 38 for Kananaskis Country and adjacent portions of the Bow Crow Forest of south-western Alberta. These low numbers, coupled with some of the grizzlies' other biological traits, mean that grizzly bear mortality management is fundamental to population persistence. This is especially true for adult female grizzly bears which are the reproductive engine of the population.

Our study of grizzly bear mortalities and removals (here after referred to as mortalities) in Kananaskis Country revealed that the grizzly bear hunting closure instituted in 1970 appears to have been successful at bringing mortality levels within scientifically accepted limits. Human-induced mortalities have not been eliminated, though they have been significantly reduced. We estimate a human-induced, known mortality rate for the period $1972-1997$ of $2.9 \%$ (32 known mortalities; 1.2 year). Females contributed only $0.9 \%$ to this overall rate. Even if these estimates are off by $100 \%$, which is unlikely, the total human-caused mortality rate is still below $6.5 \%$, the scientifically accepted rate below which such mortality is not considered a cause of population decline. However, current mortality rates may continue to increase, even without more recreational use or development, as older adult females, who have had many years to adjust to changing land uses, are replaced by young females who have to develop home ranges without long term knowledge of resources or human influences on the landscape.

Also, the Kananaskis mortality rate must be considered in the regional context where grizzly bear hunting still occurs. Other mortality sources are in some places not as conservatively managed as in Kananaskis Country. Both in Kananaskis Country and regionally, human developments and activities both stress grizzly bears and increase 

mortality probabilities. Mortality probabilities through interaction with people will probably increase as Calgary and surround continue to grow and place more recreational and other resource demands on Kananaskis Country.

Human-induced grizzly bear mortality is still the primary management concern for grizzly bear persistence. Our study of mortalities showed that the majority $(53 \% ; 17 / 32)$ were related to ungulate hunting. The majority of these were classified as being illegal kills (8) or self-defence (6). Only one was the result of legal hunting. Two were killed by Treaty Indians. Problem wildlife related grizzly bear mortalities are becoming increasingly important. During 1981-1997, 44\% (11/25), of all mortalities were of this type. Problem wildlife situations involving grizzly bears result from a juxtaposition of important grizzly bear resources, such as berries or early season grasses, with zones of human activities such as roadsides or golf courses. They also result from breakdowns in Kananaskis Country's generally excellent management of people's foods and garbage which may become dangerous attractants for grizzly bears. Most grizzly bears died in areas where human access was good. Ninety-six percent (24/25) of all mortalities where location could be determined were within $500 \mathrm{~m}$ of a road or $200 \mathrm{~m}$ of a trail. This demonstrates the strong relationship between access and grizzly bear mortalities.

While current mortality levels appear to be acceptable for population persistence, data regarding births and recruitment into the adult population, the other essential dimension of a viable population, suggest concern because of very low cub production. The only reported, scientifically vetted estimate of the average number of young produced by Kananaskis Country adult female grizzly bears per year is 0.46 (Wielgus and Bunnell 1994). This is one of the lowest reproductive rates reported in North America. Wielgus and Bunnell (1994) believe this low rate may be the complex consequence of high adult male mortality in the broader region, with this leading to a preponderance of young adult males that potentially and actually kill cubs, and because of this displace adult females from high quality habitats which they need to produce larger litters.

Currently we do not know whether the Kananaskis Country and regional population is increasing or decreasing. One of the major research objectives of the Eastern Slopes Grizzly Bear Research Project is to determine this. Unfortunately scientifically acceptable estimates of growth rate require 5-10 years of reproductive and mortality data. We will provide an estimate as soon as data are sufficient.

\section{Grizzly bear habitat, movements and security}

\section{$\underline{\text { Habitat and movement areas }}$}

Relatively low grizzly bear population number, density and reproduction relate fundamentally to habitat productivity, especially of energy rich foods such as berries and ungulates. Our major efforts regarding grizzly bear habitat classification and mapping showed a patchy distribution of highly suitable habitat and associated food resources. This is the biophysical reason for the large home range sizes we have found for grizzly bears in the region (300 sq. $\mathrm{km}$. for females, $1500 \mathrm{sq}$. km. for males). Grizzly bears must 

be able to move widely and safely throughout their home ranges to access seasonally available resources. This is why developments and human activities must be carefully managed if grizzly bears are to be maintained. This is particularly important along important movement areas which give certain grizzly bears access to different watersheds isolated by mountain ranges. Examples of these are given (see Wildlife movement areas of Kananaskis Country, p.17). Some particularly important ones, from north to south, appear to be: Skogan Pass, Goat Creek, the south end of Spray Lakes, Burstall Pass, Little Elbow/Evans Thomas Pass, North Kananaskis Pass, Elbow Pass, Elk Pass, Highwood Pass, Weary Creek Gap, Fording River Pass, and a series of drainages from south Kananaskis Country into the Oldman and Livingstone River Valleys.

Suitable habitat (habitat quality)

(see pp. 19-22, and Maps 5 and 6, pp. 23 and 24, for principal findings)

For analysis purposes we divided the grizzly bear foraging season into two ecologically defined periods. The first being before berries are ripe, and the second when berries are ripe and afterward. Generally, habitat suitability varies spatially and seasonally based on the occurrence of key plant and animal foods on the landscape.

During the pre-berry season concentrations of highly suitable habitat were found in the areas immediately south and north of Spray Lake, the Elk Pass area, the Smith-Dorrien River Valley, and on private lands between Bull Creek and the Highwood River east of Highway 541. During the pre-berry season, highly suitable habitat tends to cluster along most major river systems including the Kananaskis, Highwood and Bow River valleys. This was especially true for areas in the north-western Main Range portion of Kananaskis Country where there is a lot of rock and ice and only patches of grizzly bear habitat. Areas of high habitat suitability during the pre-berry season tended to be more extensive and evenly distributed in the Front Ranges. This was related to large amounts of south to west facing Aspen, Lodgepole Pine forests, low elevation grasslands, and riparian forests. This was consistent with grizzly bear telemetry research findings that show spring and early summer movements of especially male bears to front range habitats.

Patches of highly suitable habitat were more localized during the berry-and-after season. Notable areas of concentration of highly suitable berry-and-after season habitat included: the Odlum and Loomis Creek valleys and the southwest-facing slopes of the Highwood Range; the headwaters of Etherington Creek, Baril Creek, and the valley sides of Cummins and Lost Creek; the Smuts Valley off of the Smith-Dorrien Creek; the Cox Hill - Jumpingpound Creek area; the upper extent of Threepoint Creek, and the Moose Mountain Creek - Jumpingpound Mountain area. Highly suitable berry-and-after season habitats are generally limited in eastern portions of the Front Ranges in Kananaskis Country. 

Habitat effectiveness

(see pp. 25-29, and Table 5, p. 25, for principal findings)

To estimate the extent to which peoples' developments and activities influenced grizzly bear use of habitat we applied two models developed in the United States and widely accepted as first approximations of human influence on habitat use, alienation and security. These were the habitat effectiveness model and security area analysis.

Habitat effectiveness values estimate the percentage of habitat that is available after subtracting habitat alienated as a result of human influences. Units of analysis approximate the size and character of a female grizzly bear's home range and are called Bear Management Units (BMUs). For 13 BMUs in Kananaskis Country, habitat effectiveness values ranged from $49 \%$ to $82 \%$ and averaged $71 \%$. In Banff National Park prior work showed an average habitat effectiveness value of $83 \%$. The lowest habitat effectiveness values (below 70\%) in Kananaskis Country were found in BMUs in the western Main Ranges. Generally these were areas where roading and recreational development and activities were greatest. BMUs associated with the inter-mountain ranges further east generally had few primary or secondary roads and had highly effective habitat.

Research in the United States suggests that habitat effectiveness values of less than 70$80 \%$ could exceed the grizzlies' threshold of acceptance of disturbance and lead to abandonment of the area for other than occasional foraging. Low habitat effectiveness values also increase mortality probabilities for grizzly bears. Five of thirteen BMUs in Kananaskis Country had habitat effectiveness values of less than $70 \%$ suggesting considerable stress on grizzly bears using these areas.

\section{Habitat and security}

(see pp. 29-42, and Maps 8-11, pp. 33-39, for principal findings)

The other technique we used to understand the relationship between people's developments and activities and grizzly bear habitat was security area analysis. Through this technique, which we applied to female grizzly bear home ranges found in Kananaskis Country and the greater region (Central Canadian Rockies Ecosystem), we identified the percentage of each of 20 adult female grizzly bears' home ranges that was free enough from development to offer a low probability of disturbance during daily foraging activities. This "secure" habitat is fundamental to fostering behavioural avoidance of people. It helps to discourage habituation and food-conditioning which may lead to grizzly bears being removed as problem wildlife.

Security area analysis showed that of four jurisdictions studied, Kananaskis Country had the largest percentage (38\%) of its landscape classified as being within the zone of high human influence. An additional $24 \%$ of Kananaskis Country was classified as unsuitable habitat because it was non-productive rock or ice. This left only $38 \%$ of Kananaskis Country's land in secure status. Throughout the region of our analysis which included 

Banff, Yoho and Kootenay National Parks, and adjacent Alberta and British Columbia crown lands, the three most affected female home ranges were all exclusively within Kananaskis Country. All female home ranges in Kananaskis Country fell below regional average habitat security values of $44 \%$. This helps to explain the growing problem with habituated grizzly bears and with grizzly bear mortalities classified as problem wildlife. Grizzly bears are finding fewer and fewer opportunities to meet their daily or yearly needs without association with people. In the United States target values for habitat security are tentative, but range from $57 \%-67 \%$, well beyond the Kananaskis Country value of $38 \%$. Projection of proposed development and use trends into the future showed grizzly bear habitat being fractionated into ever smaller non-disturbed units thus further stressing individuals and the population.

Assessment of both habitat effectiveness and security area analysis suggest significant to severe stress on grizzly bears in Kananaskis Country. Our results suggest this contributes significantly to mortalities. It may also contribute to low cub production.

\section{Recommendations}

1. Regarding grizzly bear mortality and reproduction:

Because effective management of human-caused grizzly bear mortality, especially for females, is fundamental to population persistence there is a need for explicit, sex specific, mortality targets and regular monitoring and analysis of mortalities in this regard. There is also a need for management actions that will continue to decrease mortality probabilities. Such actions should include:

a. To help decrease problem wildlife removal of grizzly bears, continue the emphasis on decreasing the availability of human-related attractants such as peoples' food and garbage. This could be achieved by enacting regulations that would require all campers (hikers, equestrian, and hunters) to store food, garbage, and horse feed in bear proof metal or seamless PVC containers, or to effectively elevate such attractants between two trees.

b. To address the increased mortality risk for grizzly bears that have little habitat security and must live near people in high use areas (such as the Ribbon Creek-EvansThomas Creek area) and hence become habituated (used to being near people), better management of people with guns is needed. This could be achieved by: 1) implementing roadside wildlife sanctuaries, such as already exist in the Highwood Pass area, along all driveable roads in Kananaskis Country, 2) providing funding to continue and expand comprehensive and intensive management of grizzly bears including aversive conditioning of roadside grizzly bears and bears entering areas of concentrated human activities.

c. To address the increased mortality risk to grizzly bears associated with corridors of human access (95\% of all human-caused grizzly bear mortality occurred nearby roads or trails) careful review and management of human access is needed. 

d. To further protect adult female grizzly bears and their families, continue to implement closures when grizzly bear family groups are using important feeding sites that have transient human use, or when a female displays defensive or protective aggressive behaviour.

e. To further decrease chances of grizzly bear mortality and human injury, continue and expand efforts at informing the public about bear activity in Kananaskis Country. Also, continue the educational programs suggesting how to behave in grizzly bear country. Some programs should be developed specifically for groups most likely to cause avoidable grizzly bear mortality (e.g., ungulate hunters, backcountry campsite users, mountain bikers). A unique opportunity to inform ungulate hunters regarding grizzly bear behaviour and ecology exists for those chosen in limited entry draws which take place each year for Kananaskis Country.

f. To scientifically determine whether the Kananaskis Country and regional grizzly bear population is increasing or decreasing, continue to financially support at least this aspect of the Eastern Slopes Grizzly Bear Project. This will require long term data not only on mortality but also on reproduction.

\section{Regarding grizzly bear habitat, security areas, and movements:}

Suitable habitat has a restricted and patchy distribution, and both habitat effectiveness and habitat security were found to be significantly compromised, thus increasing mortality probabilities. For these reasons, policy changes and enabling planning and management actions are needed to restore and maintain productive habitat less compromised by people's developments and activities. We recommend the following:

a. Particular attention should be given to preventing further loss of habitat effectiveness and security especially in high quality habitats where highly suitable seasonal grizzly bear habitat exists. Such areas have been tentatively identified in our research and in previous research by McCrory and Herrero (1983a,b) and by McCrory et al. (1982). Examples of such sites would be all valley bottom locations in the main ranges, but especially the southern end of Spray Lake and the Evans Thomas Creek fan. Each development proposal should be carefully weighed in terms habitat suitability, effectiveness loss and loss of habitat security.

b. Human impacts on movement areas (see p. 17) that grizzly bears use should be managed at levels that will encourage movement by grizzly bears, taking into account the results of our habitat security analysis.

c. Steps should be considered to increase habitat suitability (quality) for grizzly bears, especially for energy rich foods such as berries and ungulates. The use of fire, creation of selective clearings, and even certain designs of timber harvesting can potentially enhance grizzly bear habitat. Fire suppression policies have probably significantly 

decreased habitat productivity for ungulates and grizzly bears. Habitat enhancement measures must begin by creating suitable habitat. In addition, human access to this habitat must be managed to encourage grizzly bear use, as habitat effectiveness and security are also important.

\section{Regarding scientific research on grizzly bears and the relationship of such} knowledge to regional land use policy formation, planning, and management:

Because certain aspects of grizzly bear biology make their populations susceptible to decline, and because human activities and developments continue to expand in Kananaskis Country and impact grizzly bear population and habitat, there will be a continuing need to financially support research that provides defensible, scientific information on grizzly bear population and habitat status. Since some of this knowledge is best portrayed in models such as the habitat effectiveness model and Security Area Analysis, model assumptions such as thresholds related to human use levels and the zone of influence of human use need further research to gain greater precision. Also, research linking habitat suitability (quality), effectiveness, and security with population viability should be supported. This could contribute significantly to more science-based population and habitat management. This evolving knowledge needs to be formally and regularly input into regional policy and planning decisions. It needs to be implemented by managers who have the necessary finances and person power. 



\section{INTRODUCTION}

For millennia, grizzly bears (Ursus arctos horribilis) have been part of the landscape now designated as Kananaskis Country. They shared this land with many other species, including First Nations peoples. With careful management of mortality, habitat, development, and people's activities within the broader region that the Kananaskis Country grizzly bear population is part of, this species can remain, even as the region and Calgary continue to rapidly grow. However, persistence of grizzly bears will be challenged by ever expanding recreational and resource extraction pressures in Kananaskis Country and surround. Grizzly bears have been removed from all but small remnants of their range in the lower 48 states where "threatened" populations, in total numbering fewer than 1000, survive only because of extraordinary efforts mandated by the United States Endangered Species Act. In Alberta, the population has decreased from an estimated 6000 before European settlement, to an estimated 800 today (Herrero 1992). We will show that grizzly bear numbers in Kananaskis Country are already depressed from historical levels, especially in the eastern portions of Kananaskis Country.

We suggest that if a healthy grizzly bear population can be maintained in the region which Kananaskis Country is part of, then many other land-based species such as wolverine, elk, moose and wolves will probably also survive. This is because the grizzly, though physically (and to many) spiritually powerful, is among the easiest species to eliminate from an area. Sows have few young, on average only about half a cub a year during adulthood (Wielgus and Bunnell 1994). Adults range widely; our results indicate lifetime home ranges of about $300 \mathrm{sq}$. $\mathrm{km}$. for females, and $1500 \mathrm{sq} . \mathrm{km}$. for adult males (Gibeau and Herrero 1997). Grizzly bears exhibit wide-ranging movements and an avoidance of areas where people are frequent. But with their affinity for people's food and garbage, and their desirability as hunting trophies, populations can easily be placed in jeopardy unless mortality and the landscape are carefully managed.

In this document, we present a simplified and preliminary analysis of the results of four years of research, 1994-1997, on grizzly bears resident in the Central Canadian Rockies Ecosystem, but focusing on Kananaskis Country (Map 1). Kananaskis Country is an integral portion of this broader population and landscape unit. Grizzly bears and other large mobile species move throughout this area, without reaction to the administrative boundaries that people have established that form Kananaskis Country, the various Rocky Mountain National Parks, British Columbia and Alberta Forest Service Land or other jurisdictions. Within this context we examine Kananaskis Country as grizzly country. 



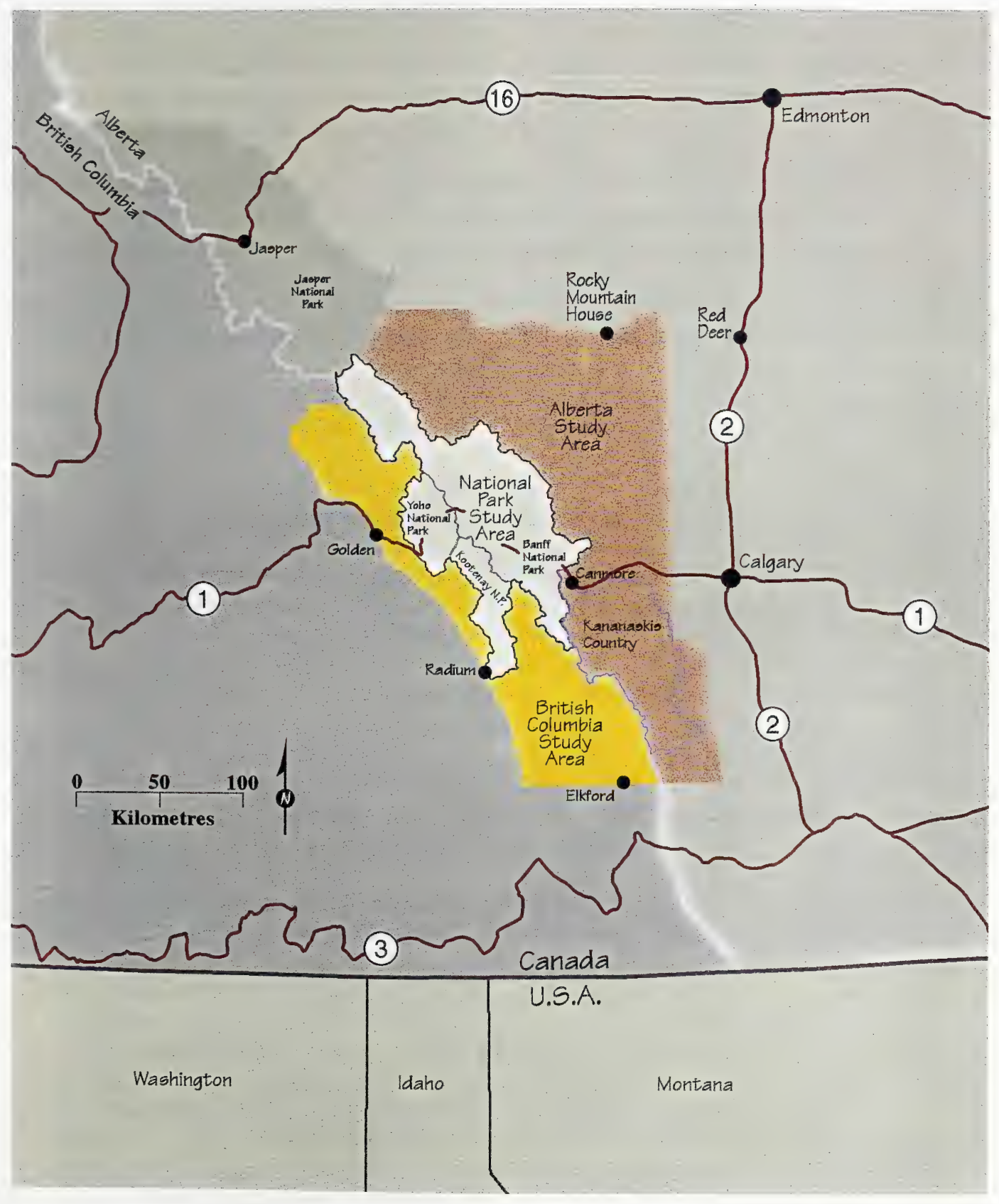

Map 1. The Kananaskis Country study area within the larger Central Rockies Ecosystem study area of the Eastern Slopes Grizzly Bear Project. 



\section{Grizzly bears as an indicator of ecological integrity}

Many regard the status of grizzly bears in an area as an excellent indicator of ecological integrity. In the United States, grizzly bears were identified by land managers as the key indicator of environmental quality in the Northern Rockies (Bader 1995). In Alberta, recent land use public hearings regarding the environmental effects of proposed large scale developments have each included major emphasis on the potential impacts of grizzly bear populations (NRCB 1993a; 1993b; ERCB 1994).

The presence of healthy grizzly bear populations in areas where they are indigenous is an excellent indicator of how well people's impact upon a region is being managed. The status of grizzly bears in an area can be regarded as being a "coarse filter" (Noss 1987) indicator of the status of biodiversity, especially regarding terrestrial ecosystems. By maintaining grizzly bears and the natural ecosystems upon which they depend, the habitat and populations of many other species are also maintained (Noss et al. 1996). For example, Paquet (pers. comm.) analyzed niche overlap for 410 terrestrial vertebrates in the Central Canadian Rockies. He found that by protecting the habitat needs of grizzly bear, lynx, and wolves, the habitat for 403 additional species $(98 \%)$ would also be protected.

\section{$\underline{\text { Life history parameters and human interactions }}$}

Grizzly bears are indicators of ecological integrity because of certain life history parameters and the nature of their interaction with human beings. The species is reproductively conservative, exhibiting low resilience to human disturbance to habitat and populations (Weaver et al. 1996). In Kananaskis Country, Wielgus and Bunnell (1994) reported an estimated reproductive rate (that is, the average number of cubs a female grizzly bear has per year during her reproductive period) of only $0.46 \mathrm{cubs} / \mathrm{year}$. Furthermore, the age of first reproduction is usually delayed in grizzly bears, not occurring until 4-8 years (Herrero 1978; LeFranc et al. 1987). This further decreases the potential reproductive output of grizzly bears as compared to species such as elk where females begin reproducing as early as yearlings.

Another life history parameter that makes grizzly bears a good indicator of ecological integrity is their spatial needs. Because of their large home range sizes, many grizzly bears enter several different jurisdictions during a year. For example, Knight (pers. comm.) found that the average grizzly bear in the Yellowstone Ecosystem entered 4.2 different management jurisdictions a year. Raine and Riddell (1991) reported similar results regarding grizzly bears in Yoho and Kootenay National Parks. Within each of the management jurisdictions a grizzly bear enters it must survive and find acceptable habitat if it is to persist. The large spatial needs of grizzly bears have led to the need for interagency and multi-stakeholder management because protected areas by themselves are seldom large enough to house viable grizzly populations (Newmark 1985; USFWS 1993; Herrero 1995). An appropriate landscape scale for managing grizzly bears is the Central Rockies Ecosystem. This includes Banff, Kootenay, and Yoho National Parks, and adjacent portions of the provinces of British Columbia and Alberta, including Kananaskis Country. 

A final important life history parameter that makes grizzly bears a good indicator of ecological integrity relates to their population densities. While male home ranges overlap, female home ranges usually only have a small degree of overlap. This means that grizzly bears occur at low population densities. Hence, a given area of land does not support many grizzly bears. In Kananaskis Country, Wielgus and Bunnell (1994) reported bear densities of $1 / 62.5 \mathrm{~km}^{2}$. In Jasper National Park, Russell et al. (1979) reported densities between $1 / 85.5 \mathrm{~km}^{2}$, and $1 / 101.6 \mathrm{~km}^{2}$.

In addition to being a biologically conservative species, grizzly bear viability is more directly susceptible to management actions than most species. Grizzly bears sometimes injure people (Herrero 1985). Because of this trait, managers sometimes find it necessary to remove certain individual bears. This can further depress grizzly bear populations.

\section{Objectives of our research}

Alberta Environmental Protection, Natural Resources Service asked the Eastern Slopes Grizzly Bear Research Project to prepare a report on the status of the grizzly bear population and habitat, focusing on the Kananaskis Country area because extensive development has occurred there. While the Eastern Slopes Grizzly Bear Research Team is currently studying the relationships between grizzly bear ecology and human activity as part of a major research effort, our final results will not be available until the year 2000 . The Eastern Slopes Grizzly Bear Research Project began in the summer of 1994. Valid estimates of population vital rates for grizzly bear take between five to ten years of data to be bounded within scientifically acceptable confidence limits (Hovey and McLellan 1996).

Since scientifically based population parameter estimates are not available we employed four different techniques to derive best estimates of grizzly bear population and habitat status:

(1) We summarized and analyzed data on grizzly bear mortalities in Kananaskis Country historically and from 1971 to 1997 ;

(2) We mapped and analyzed grizzly bear habitat quality (referred to as suitability);

(3) We conducted a habitat effectiveness analysis (Weaver et al. 1986; USDA Forest Service 1990; Gibeau 1995) of the effects of development and human activities on grizzly bear habitat in Kananaskis Country;

(4) We conducted a security area analysis (Mattson 1993; Puchlerz and Servheen 1994) to determine the size and quality of areas where female grizzly bears would have a low probability or encountering people in Kananaskis Country and the Central Rockies Ecosystem.

\section{Acknowledgements}

We acknowledge the West Slope Grizzly Bear Project for providing telemetry data on 5 adult female grizzly bears. 

We also appreciate the time and comments on grizzly bear management and specific details provided on individual incidents by Alberta Fish and Wildlife Officers Richard Bryant, Dave George, Miles Grove, Stan Hawes, Rocky Horning, Dick Mann (Ret.), and Jack Morrison (Ret.), and all other wildlife managers and hunters who provided information with respect to specific mortalities.

Four GIS experts each made tremendous contributions to this document - Rich Ashton, Scott Jevons, Mark Lindberg, and Jack Wierzchowski. 



\section{POPULATION OVERVIEW}

\section{Historical}

In 1980, Alberta Fish and Wildlife contracted a review of the historical status of grizzly bears in Kananaskis Country (McCrory and Herrero 1982). Most of the information in this section comes from that document and a related subsequent one (Herrero 1994).

Prior to the arrival of European settlers, almost all of Alberta, except areas without vegetation such as glaciers, rock slopes, and sand dunes, appear to have provided at least seasonal habitat for grizzly bears. A conservative estimate of their pre-European numbers is 6000 (Herrero 1992).

As settlers moved into the province in the 1870 s and 1880 s grizzly bears were systematically killed, especially in agricultural zones. A major pressure on all wildlife was market hunting. For example during the winter of 1871, at the Cypress Hills, Hudson Bay Company fur-trader Isaac Cowie traded 750 grizzly bear hides (Stegner 1962: p. 70). He estimated that independent traders also got at least as many.

Nearby, in what is now Kananaskis Country, the Hudson Bay Company established Peagan Post on the north side of the Bow River between Morley and Exshaw. The post only operated for two years. They reported 23 grizzly bear pelts traded during 1832, and 33 during 1833. Some of these would have come from the prairie, representing a population that was eliminated, along with bison, by the late 1880 s. Also nearby current Kananaskis Country, it was during the 1880 s that both grizzly bears and bison were eliminated from prairie portions of the Bow and Highwood drainages. Thus, market hunting to sell pelts, and grizzly bear killing to make way for agriculture, eliminated grizzly bears from the prairies east of Kananaskis Country.

As cattle ranching moved into the foothills in the 1880 s, widespread killing of grizzly bears began. Killing of grizzly bears by ranching interests reached a peak during the late 1940s and early 1950s (Map 2). A minimum of 20+ grizzly bears were killed in the eastern portions of Kananaskis Country during this period. The actual number could have been several times greater. Records were not kept. Only anecdotal evidence exists.

Impacts on grizzly bears from rancher-induced control were augmented in 1952 with the construction of the Forestry Trunk Road up the Highwood Valley. Now recreational hunters had access to today's Kananaskis Country. Killing of grizzly bears continued with little effective regulation, until the 1960s and 1970s (Nagy and Gunson 1990, p.6). The hunting season for grizzly bears was closed south of the Bow River in 1970 because of excessive mortality and declining populations. The hunting season was opened again in 1987 in Kananaskis Country, but was closed after the one season. From interview data, McCrory and Herrero (1982) determined that about 25 grizzly bears were known to have been killed by hunters between 1960-1970 in what is now Kananaskis Country. Despite protection from hunting, between 1970-1997 at least 32 grizzly bears were killed or removed by people in and around Kananaskis Country (Map 2). 



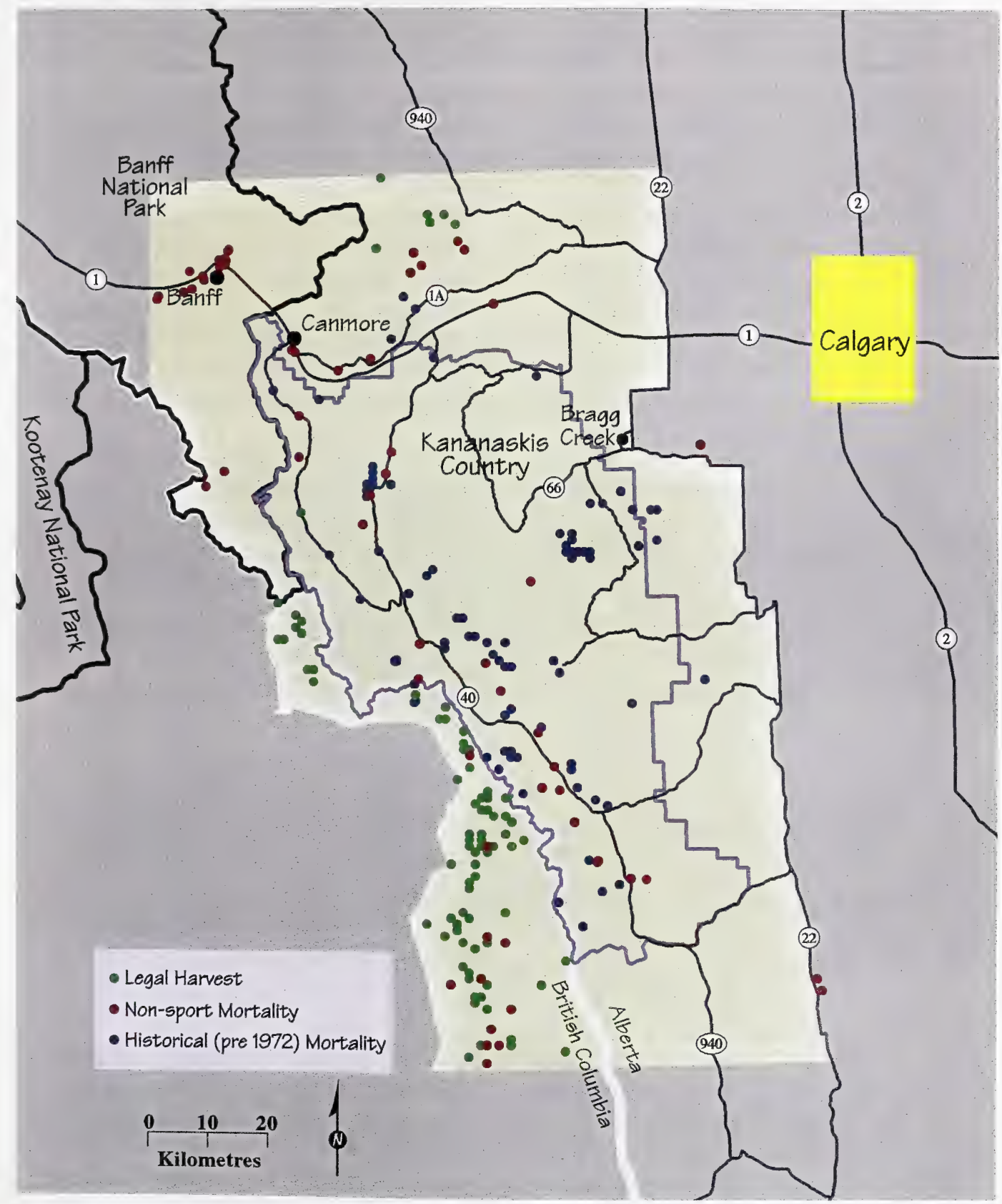

Map 2. Location of historical and current grizzly bear mortalities in and nearby Kananaskis Country. 
Grizzlies survived in the western portions of Kananaskis Country primarily because of protective status and difficult access. Rocky Mountains National Park was established during the 1880s. Until 1930, much of Kananaskis Country was protected as part of this Park. With the Transfer of Resources Act of 1930, the Kananaskis and Spray Valleys were put under Provincial jurisdiction. From 1930-1956 grizzly bears were protected as part of the Provincial Kananaskis Game Reserve. Only occasional hunting by Stoney Indians, along with some poaching, occurred. These areas probably provided reservoir populations of grizzly bears which continued to disperse eastward.

Another important historical event influencing grizzly bears in Kananaskis Country was the establishment of the Bow-Crow Forest Reserve in 1918. Much of Kananaskis Country is within this jurisdiction. This protected most of the area from permanent human settlement---a bold and important step for wildlife, watershed, and forest management. However, logging, mining, oil and gas exploration and development, cattle grazing, recreation and other uses were allowed. This gave grizzly bears some degree of habitat protection, albeit in competition with these various resource uses.

Even with these protective measures in place, the following comments from Noble (1972) indicate that excessive grizzly bear killing was occurring throughout the Central Rockies during the 1940s, 50s and 60s:

- the East Kootenays accounted for a substantial portion of all grizzly bears killed in BC (1940s and 1950s; Pearse and Bowden in Noble 1972)

- improved access led to a large number of grizzly bears killed in the Mitchell River area outside (south) of Banff National Park (1950s; Harmsworth in Noble 1972)

- during the 1950s, there was much indiscriminate and unrecorded killing by wardens in Banff National Park (Noble 1972)

- possibly hundreds of grizzlies were killed during the 1950 s rabies control campaign (Ballantyne in Noble 1972)

- improved access led to heavy hunting along the east boundary of Banff National Park, such that harvest success and ages declined (1950s; Woledge in Noble 1972)

- more than 500 grizzly bears were shot in the East Kootenays between 1959 and 1969 (Demarchi in Noble 1972)

- the number of grizzly bears killed in Banff and Yoho national Parks in the 1970s may have been as high as 90 (Cottingham and Langshaw 1981)

As of 1990, population estimates were 200 in the national parks and 600 on other provincial lands (Nagy and Gunson 1990). In response to province-wide over harvest, especially during the 1980 s, Alberta introduced more regulated, limited entry grizzly bear hunting between 1983 and 1988. Because of this, the provincial population may be increasing, although in visually open areas, such as sub-alpine zones, harvest in the 1990s continued to be in excess of recovery targets (Gunson 1996). In addition, resource extraction, recreation and other human developments and activities continue to compromise grizzly bear habitat. 
When Kananaskis Country was established in 1977 (by the Policy for Recreation Development of Kananaskis Country), the nature of grizzly bear habitat began to change dramatically. On the positive side, in 1981 many dirt roads and trails were closed to motorized traffic thus offering more habitat security for grizzly bears and potentially less conflict with hunters seeking ungulates. Also positive, the placement of many trails and some campsites depended upon their relationship to grizzly bear habitat (Herrero et al. 1986). This was done to provide some measure of separation of human and grizzly bear activities. It may have contributed to human safety as there have been no injuries inflicted by grizzly bears since Kananaskis Country was created. At the same time, though, major development of Kananaskis Country proceeded with in excess of 200 million dollars being spent on paved roads, upgrading the Smith-Dorrien road, and construction of a world class golf course, a resort village, larger campgrounds, and other facilities (Herrero et al. 1986). Human use of Kananaskis Country continues to rise rapidly. The future of grizzly bears will depend upon careful planning of facilities and human activities, so as to respect the needs of each species.

\section{Current}

As noted, grizzly bears were almost eliminated from the eastern portions of Kananaskis Country. Known historical mortalities (pre-1972) appear in groups east of the Kananaskis and Highwood River valleys, whereas more recent mortalities show up mainly in the western mountainous parts of the Kananaskis (Map 2).

Restrictions to motorized access in 1981 reduced the human presence in the backcountry for a few years, and grizzly bear populations may have rebounded in the eastern portions of Kananaskis Country. Increased numbers of sightings have been reported in these areas (R. Bryant pers. comm.). However, improvements to main roads and construction of, and improvements to, recreational facilities, have led to increases in non-hunting recreational use throughout Kananaskis Country. This is becoming a serious problem for grizzly bears, as more people along roads and trails lead to bears under-utilizing good quality habitat, as well as an increase in the mortality risk for the bears.

The major mortality factor since the grizzly bear hunting closure in Kananaskis Country is still hunting-related - self-defence or illegal actions by hunters pursuing other game animals, and hunting by First Nations People. However, Alberta Parks, and Fish and Wildlife personnel have had to act on increasing numbers of complaints, mostly close encounter situations, from recreationalists (R. Bryant and R. Horning pers. comms.). As well, agency control actions have increased in frequency over the years, leading to higher average annual grizzly bear mortality in Kananaskis Country and adjacent lands (see Grizzly bear mortality; Results and discussion; Mortality summaries and rates).

As mentioned earlier, grizzly bear hunting south of the Bow River was closed in 1970 due to fears of a declining population. With increased sighting reports, hunting was reopened in 1982 in south-western Alberta south of Kananaskis Country, and for one year only, in 1987 in the Kananaskis. Kananaskis Country is managed for the "nonconsumptive use of the grizzly bear resource", and planning of human use and public 
education are the main strategies for preventing bear-human conflict (Nagy and Gunson 1990).

There have been several grizzly bear population estimates generated for Kananaskis Country and surround. The scientific validity of them is compromised by small sample size and methodological problems. Carr (1989) estimated the population at 50 in Kananaskis Country and 77 in an expanded area delineated by the movements of a marked sample of grizzlies. Wielgus and Bunnell (1994) reinterpreted the same data and estimated a population size of 38 bears for Kananaskis Country and the Bow Crow Forest of south-western Alberta. By summing the estimates from Wildlife Management Units (from Nagy and Gunson 1988) south of the Bow River and within the Central Rockies Ecosystem, the population estimate is 42. Gibeau and Herrero (1998) estimate the population at 50 grizzlies within Kananaskis from a DNA hair-sampling study. However, based on personal observations, Gibeau (pers. comm.) feels that this may be higher than the actual population size. Certainly the population is small and merits careful management.

It is important to consider the grizzly bear population that uses the Kananaskis area in the larger landscape. Grizzlies, in particular males, range widely and must contend with different management strategies in different jurisdictions. "Kananaskis" grizzlies frequently die beyond the boundaries of Kananaskis Country (Carr 1989; Wielgus and Bunnell 1994; Gibeau and Herrero In press; Benn In prep.). Map 2 shows a higher density of recent (1971-97) legal and non-sport mortalities north of the Bow River, around Banff townsite, and in the East Kootenays. The Banff National Park and Alberta mortality has been reduced in the last decade, but the East Kootenay area adjacent to the Kananaskis continues to exhibit high annual mortality, albeit from an estimated more numerous population (Benn In prep.). Carr (1989), Wielgus and Bunnell (1994) and Gibeau and Herrero (1998) all note that some marked bears from their studies died in the East Kootenays, particularly in the Elk Valley. Thus, grizzly bears in Kananaskis Country must be managed with this in mind, as a source population from which bears disperse into areas where hunting is permitted, and mortality is higher.

\section{GRIZZLY BEAR MORTALITY}

\section{Introduction}

Grizzly bear survival is contingent on a finite growth rate (no. of births / no. of deaths) of $\geq 1$ over a biologically meaningful time period (Mattson et al. 1996a). Mortality, especially in the female cohort, is the primary factor limiting grizzly bear populations (Knight et al. 1988). Historical (Storer and Tevis 1955, Young and Beyers 1980, Brown 1985) and recent works (McCrory and Herrero 1982, Mattson et al. 1996b, Gibeau et al. 1996) consistently note that grizzly bears usually die as a result of some interaction with humans. Although natural mortality of grizzly bears, especially in non-dependent age classes, is not often detected, it probably does not supplant human-caused mortality. Mattson et al. (1996a) state that the bias of oversampling human-caused mortality would have to be orders of magnitude greater, not to conclude that human-caused mortality is the greatest threat to grizzly bear survival today. 

The Alberta Natural Resources Service (Gunson 1995) states that because the grizzly bear is a high-profile species that exists at low population densities, a high proportion of human-caused mortalities and translocations have been reported. Unreported illegal kills, accidents, and wounding losses are accounted for by the addition of $25 \%$ of the total known human-caused mortality (Nagy and Gunson 1990). Some opportunistic and vandalistic killings, by their nature, are no doubt never discovered. However, premeditated poaching is probably a minor component of grizzly bear mortality in Kananaskis Country, as the low population density of grizzly bears and the low elevation forest cover in much of their range make them difficult to find.

In this section, we analyse grizzly bear mortality for Kananaskis Country and adjacent area, south of the Bow River, from 1972-97. Mortalities were analysed for the following time periods:

- 1972-80 - pre-road closures and no bear proof garbage facilities.

- 1981-96 - post-road closures and improved garbage management (bear-proof transfer system).

\section{Methods}

For a discussion of the methodology for the mortality analysis, see Appendix A (Methodologies; Grizzly bear mortality in Kananaskis Country).

\section{Results and discussion}

\section{$\underline{\text { Mortality summaries and rates }}$}

There were 32 (1.2 mortalities/year) known human-caused grizzly bear mortalities in the study area south of the Bow River from 1972-97. There were 7 mortalities $(0.8$ mortalities/year) for the period 1972-80, and 25 (1.5 mortalities/year) from 1981-97 (Figure 1). The low numbers of deaths during the early period may reflect conservationoriented management practices, a depressed population following the high mortality of the previous decades, or possibly not all mortalities were reported or recorded during this time. The mortality rate for this period, using 42 as the population estimate (see Population overview; Current), is 2.9\% (1.9\% for 1972-80; 3.5\% for 1981-97). This is well below the generally accepted rate of $6.5 \%$ for total human-caused mortality not leading to population decline (Harris 1986).

Carr (1989) calculated a population of 77 grizzlies in his study area, which included Kananaskis Country, noting the shortcomings of a small female sample size. The estimated composition of this population was 24.1 males, 27.5 females, and 25.2 dependent bears. The number of young bears will vary greatly between years, however, using the ratio calculated by Carr (1989), the population estimate of 42 would be composed of 13.1 males, 15.0 females, and 13.7 dependants. The male, female and dependent contributions to the overall mortality rate $(2.9 \%)$ are then $1.7 \%, 0.9 \%$ and $0.3 \%$, respectively. From the early to late analysis period, the male contribution increased 

from $0.3 \%$ to $2.5 \%$. The female portion dropped from $1.1 \%$ to $0.8 \%$, and the dependent contribution from $0.5 \%$ to $0.1 \%$.

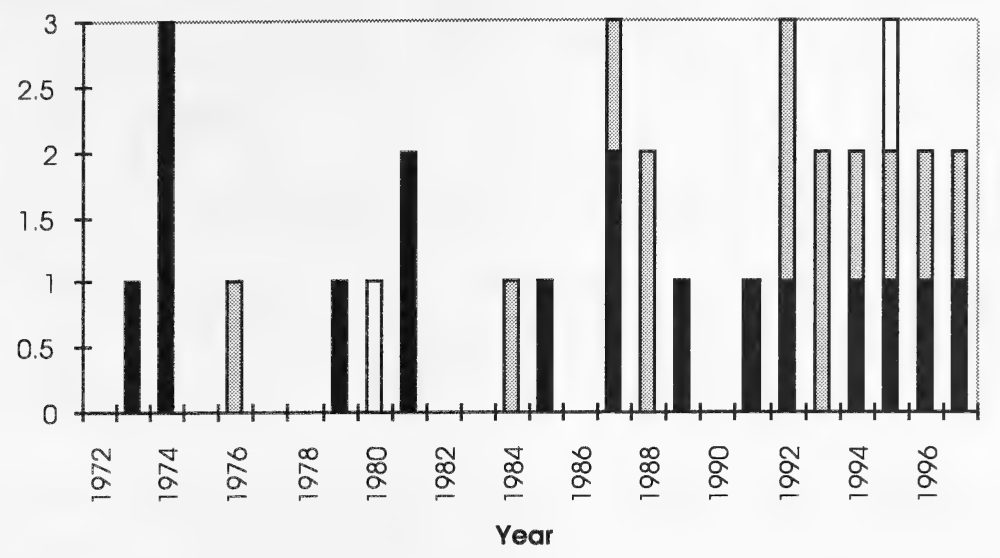

Figure 1. Annual number of grizzly bear mortalities by cause in the Kananaskis Country study area, 1972-97 $(n=32)$.

$(\mathrm{Re}=$ research, $\mathrm{U}=$ unknown, $\mathrm{PW}=$ problem wildlife control action, $\mathrm{SD}=$ self-defence, $\mathrm{IL}=$ illegal, TI = First Nations Treaty, $\mathrm{LH}=$ legal harvest)

\section{Mortality type analysis}

Hunting-related grizzly bear mortalities (SD, IL, LH and TI) accounted for 53\% (17/32) of the total known human-caused mortality over the entire analysis period (Table 1). Except for $1 \mathrm{LH}$, the hunting-related mortalities are almost all caused by ungulate hunters in the fall. The majority of the 17 mortalities were classified as being illegal kills (8) or self-defence (6). Two were killed by Treaty Indians. There was no statistically significant increase in the annual number of hunting-related mortalities from the first analysis period to the second (0.56/yr. for $1972-80$ to $0.65 / \mathrm{yr}$. for $1981-97)$. However, these causes declined from $72 \%$ of total mortality (1972-80) to $48 \%$ (1981-97). This reflects an increase in the recorded problem wildlife-related (PW) grizzly bear deaths in the study area over the analysis period. There was only $1 \mathrm{PW}$ mortality recorded in the first analysis period, and 11 in the second ( 2 PWs in the first 13 years and 10 in the second 13 years). This higher rate of bear-human conflict can be explained by a possibly growing grizzly bear population in the study area, and by increases in recreational use in the backcountry (R. Bryant pers. comm.), as well as by increases in the number of frontcountry camping sites and other recreational developments.

Table 1. Human-caused grizzly bear mortalities by cause of death in the Kananaskis Country study area for the 2 analysis periods, $1972-80$ and 1981-97. ${ }^{4}$

\footnotetext{
${ }^{4}$ During 4 years of monitoring radio-collared grizzlies by the Eastern Slopes Grizzly Bear Project, 1 cub was recorded as a natural mortality (lost between successive observations of marked females) in Kananaskis Country (Benn In prep.).
} 

1972-80 (n=7)

Self-defence - $43 \%$ (3)

Illegal - 29\% (2)

Problem wildlife - $14 \%$ (1)

Research - 14\% (1) $1981-97(n=25)$

Problem wildlife - 44\% (11) Research - 4\% (1)

Illegal - 24\% (6)

Legal harvest - $4 \%$ (1)

Self-defence - $12 \%$ (3)

Unknown - 4\% (1)

Treaty Indian - $8 \%(2)$

\section{Sex, age, and cohort}

There was a significant decline in the percentage of females in the mortalities from the first analysis period to the second (Table 2). This was a positive change. The decreased percentage may partly be a result of a small sample size in the early period. The $25 \%$ figure for the last 16 years is well below the $35 \%$ target for the female portion of total human-caused mortality set by the Alberta grizzly bear management plan (Nagy and Gunson 1990).

The age ratio in the kill changed from a high percentage of adult grizzlies in the initial analysis period, to a high percentage of sub-adult bears after 1980 (Table 2). Similarly, the cohort ratio changed from a high percentage of adult females to a high percentage of sub-adult and adult males. This may reflect a recovering population, following decades of extremely high mortality (see Population and habitat conditions; Historical overview). Wielgus and Bunnell (1994) and Carr (1989) both noted a high mortality rate of radiocollared male grizzlies marked in the Kananaskis, both in the Bow Crow Forest Reserve south of Kananaskis Country, and in the Elk Valley in British Columbia. Wielgus and Bunnell suggested that this led to an influx of sub-adult males into the area.

\section{Table 2. Human-caused grizzly bear mortalities by class, for the analysis periods} 1972-80 and 1981-97.

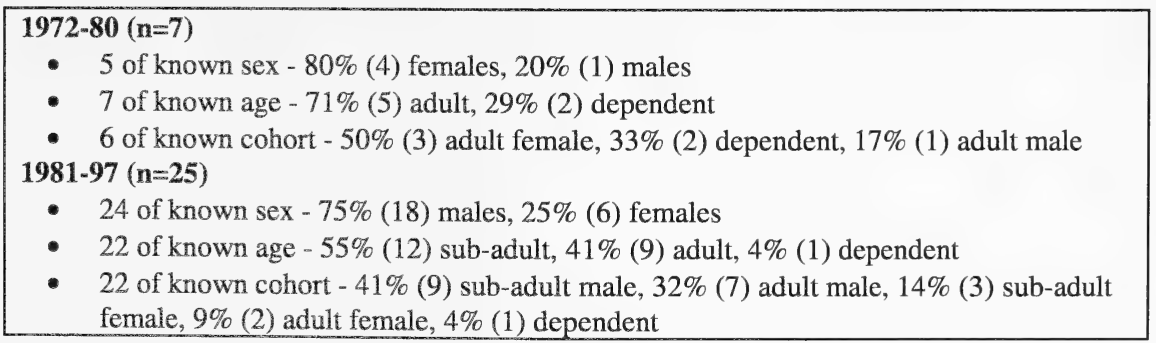

Spatial analyses

Kananaskis Country is approximately $4200 \mathrm{~km}^{2}$ and contains $653 \mathrm{~km}$ of driveable roads open to the public, and $4051 \mathrm{~km}$ of closed roads, trails, seismic lines and utility corridors (Map 3). This amounts to road and trail densities of 0.15 and $0.95 \mathrm{~km} / \mathrm{km}^{2}$, respectively. Forty-three percent of grizzly bear mortalities occurred within $500 \mathrm{~m}$ wide road buffers ( $12.4 \%$ of the study area), and $96 \%$ ( 24 of 25 in Kananaskis Country) occurred within $500 \mathrm{~m}$ road and $200 \mathrm{~m}$ trail buffers $(32.1 \%$ of the area after removing the area of road/trail overlap). Thirty-one of thirty-two mortalities fell along roads and trails in the entire study area south of the Bow River. 



\section{Elevational analysis}

Elevational analysis of mortality locations revealed that $94 \%$ of grizzly bears were killed below $2000 \mathrm{~m}(6500 \mathrm{ft}$.) and $53 \%$ died below $1700 \mathrm{~m}(5600 \mathrm{ft}$.) (Figure 2). All but one mortality occurred along a valley bottom access route (Benn In prep.).

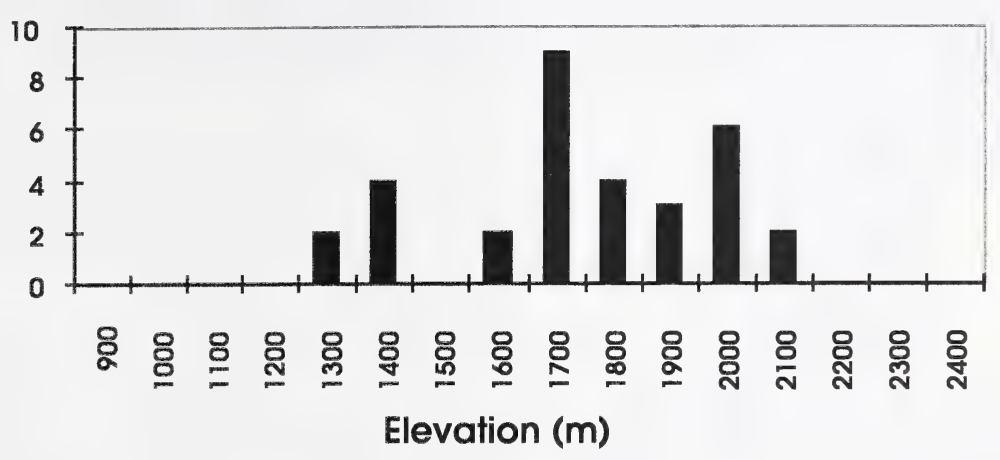

- Bow River valley - $1220 \mathrm{~m}(4000 \mathrm{ft})$ at Morley, to $1370 \mathrm{~m}(4500 \mathrm{ft})$ at Canmore

- Kananaskis River valley - $1370 \mathrm{~m}$ (4500 ft) at Barrier Lake, to $1525 \mathrm{~m}$ (5000 ft) at King Creek, to $2200 \mathrm{~m}(7200 \mathrm{ft})$ at the Highwood Pass.

- Smith-Dorrien Valley - 1680m (5500 ft) at Goat Creek above Canmore, to $1980 \mathrm{~m}(6500 \mathrm{ft})$ at the height of land below Mt. Chester, to $1680 \mathrm{~m}(5500 \mathrm{ft}$ ) at Loon Lake in Peter Lougheed Provincial Park.

- Highwood River valley - $1220 \mathrm{~m}$ (4000 ft) at Longview, to $1525 \mathrm{~m}$ (5000 ft) at Highwood Junction, to $1830 \mathrm{~m}(6000 \mathrm{ft})$ at Mist Creek to $2200 \mathrm{~m}(7200 \mathrm{ft})$ at the Highwood Pass.

Figure 2. Frequency of grizzly bear mortalities by elevation class, 1972-97 ( $n=32$ ), and elevations at arbitrary landmarks along a sample of valleys in the Kananaskis Country study area. 



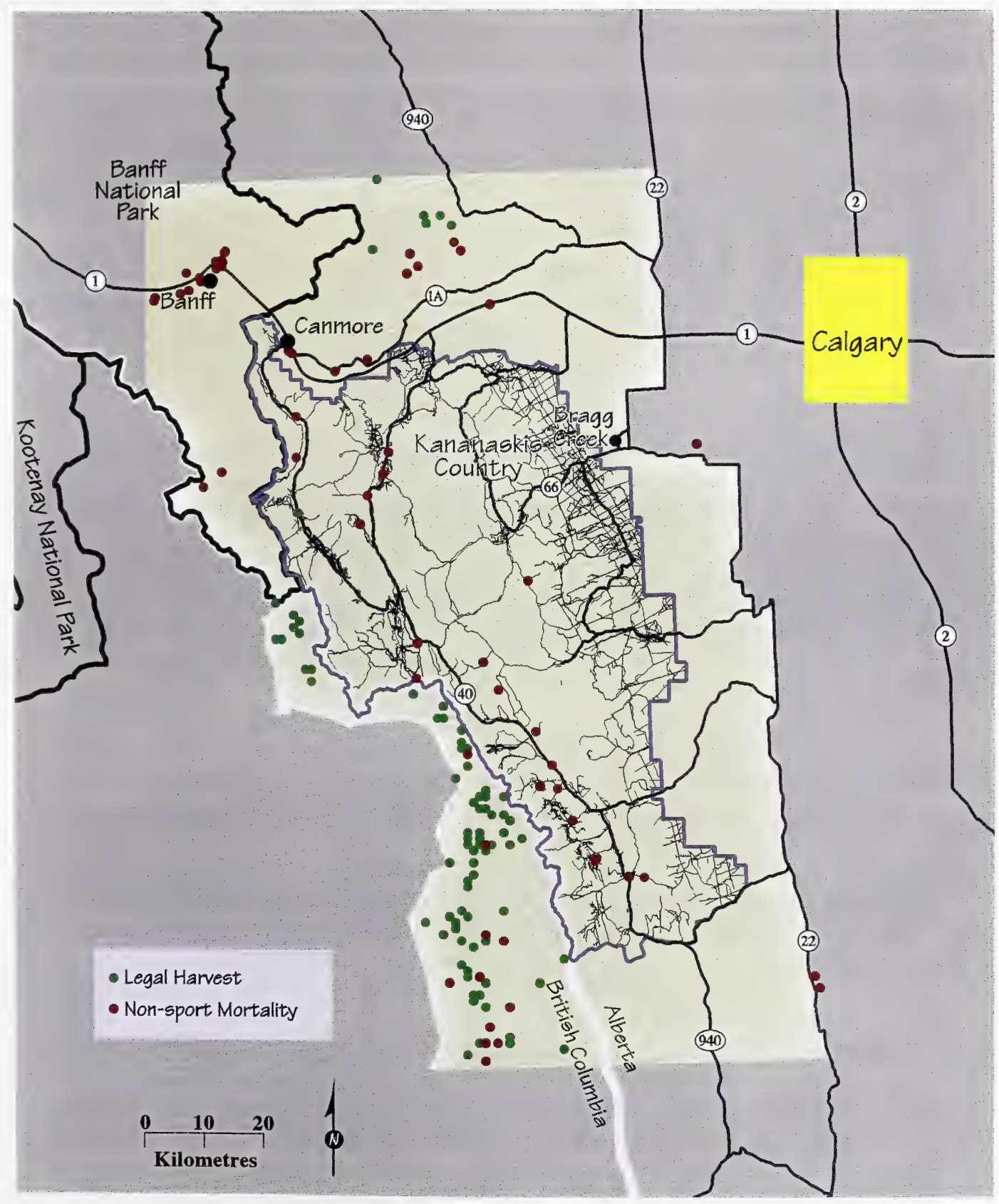

Map 3. Locations of grizzly bear mortalities in Kananaskis Country in relation to roads and trails, 1972-97. 



\section{ECOLOGICAL DESCRIPTION OF KANANASKIS COUNTRY}

\section{Vegetation communities of Kananaskis Country}

A rich and dynamic area, Kananaskis Country is composed of a diverse selection of vegetation communities due to the tremendous variation in topography, soils, and climate of the foothills and mountain landscapes. Kananaskis Country is located south-west of Calgary, and consists of roughly 4160 square kms of the Alberta Eastern Slopes Region (McGregor 1984).

The Kananaskis Country landscape is represented by a number of physiognomic cover types. Fifty-six percent of the landscape consists of coniferous forests and $25 \%$ consists of barren rock. Of the remaining $19 \%$ of the landscape, $4.5 \%$ is grassland, $4 \%$ is deciduous forest, $3.5 \%$ consists of shrubland and wetland, and another $2 \%$ is mixed-wood forest. Three percent of the Kananaskis Country land base is represented by anthropogenic features, including urban or industrial sites, agricultural areas and harvested cutblocks.

Kananaskis Country stretches from the Foothills to the front ranges of the Rocky Mountains and is characterized by 5 Ecoregions as described by McGregor (1984). These ecoregions include the Alpine, Subalpine, Montane, Boreal Foothills and Aspen Parkland zones.

The Alpine ecoregion is a high elevation landscape of rock, ice, heath and low shrub meadows, with kruppelholz Subalpine Fir (Abies lasiocarpa), Engelmann Spruce (Picea engelmannii), and Alpine Larch (Larix lyallii).

The Subalpine ecoregion consists of dense forests of Subalpine Fir, Engelmann Spruce, and Lodgepole Pine (Pinus contorta), cut by avalanche paths - swaths of grass, wildflower, and shrub meadows created by the tons of snow that roar down the mountain slopes. The alpine and subalpine ecoregions occupy the greatest area in the region.

The Montane ecoregion is found below the subalpine and in the valley bottoms of a few of the larger river systems in Alberta. It is composed of grasslands interspersed with forests of Douglas Fir (Pseudotsuga menziesii), White Spruce, Lodgepole Pine and Aspen. In and around Kananaskis Country, elements of the montane can be found in the Wind valley, the Bow valley, and the Highwood River valley.

The Boreal Foothills ecoregion occupies the elevational zone below the subalpine in the foothills and mountains of the Kananaskis. It is comprised predominantly of closed forests of Lodgepole Pine and White Spruce (Picea glauca), and is probably the largest zone of continuous forest cover in the region. The lower reaches of this zone are comprised of a mixed-wood of Aspen (Populus tremuloides), Balsam Poplar (Populus balsamifera), Lodgepole Pine and White Spruce, and a mixed-wood dominated by tall shrub wetlands, Aspen Poplar, Balsam Poplar, Lodgepole Pine, and White Spruce. This zone can be found in areas such as the lower reaches of the Kananaskis and Elbow River valleys and intermingling throughout the foothills with the Aspen Parkland. 

The Aspen Parkland is a transitional zone between the prairies and foothills. It is a warmer, drier ecoregion in the south-east of the study area comprised of Aspen forests and Fescue (Festuca campestris) grasslands.

For a more complete description of grizzly bear habitats throughout Kananaskis Country, see McCrory and Herrero (1981, 1983a,b) McCrory et al. (1982), and Kansas (In prep.).

\section{Bear Management Unit (BMUs) of Kananaskis Country}

For the purposes of this study, Kananaskis Country was subjectively divided into Bear Management Units (BMU) (Map 4). See Appendix A (Methodologies; Habitat assessment) for a description of BMU delineation, and Appendix B for a description of the ecological characteristics of each Bear Management Unit.

\section{WILDLIFE MOVEMENT AREAS OF KANANASKIS COUNTRY}

It is very important to put the Kananaskis region into the larger perspective of the Central Rockies Ecosystem. Kananaskis Country is home to many terrestrial vertebrate species, and serves for long regional movements of grizzly bears, wolves and elk. These wideranging animals require reasonably unhindered passage from valley system to valley system in order to find seasonally important foods. For animals such as these, Kananaskis Country alone is not sufficient to satisfy these needs. The Kananaskis links up with the East Kootenays of British Columbia, and Banff National Park to the west, provincial forest reserves to the north and south, and municipal and private lands to the east. All of these areas bordering on Kananaskis Country fulfil various needs for these large-bodied animals. This section deals with wildlife in general and grizzly bears where specified.

Wildlife movement areas are more than narrow strips of land that animals sneak through to get from one feeding area to the next. They have a few very important characteristics. Movement zones have relatively shallow slopes, and cross ridges and mountains at their low points where the travel is easiest. They offer food along the way, as well as good cover from predators and human interference. And finally, to enable the animals to avoid dangers and disturbances, corridors are relatively wide. Thus, movement areas run through the valley bottoms and low mountain passes with these characteristics.

Considering the size of Kananaskis Country (about 4200 sq. km.), there are only a handful of low elevation passes that serve as movement corridors throughout the mountainous areas of the region. Starting in the north, Skogan Pass links the Bow River valley and Wind valley with the Kananaskis valley, which in turn allows animals to migrate up the Evans-Thomas valley and cross a pass into the Elbow River watershed (Eastern Slopes Grizzly Bear Project data). The next low-elevation pass, Elbow Pass, is about $50 \mathrm{~km}$ by highway south of the Evans-Thomas valley. This pass allows grizzly bears access into the Elbow and Sheep River watersheds (Bryon Benn, personal 



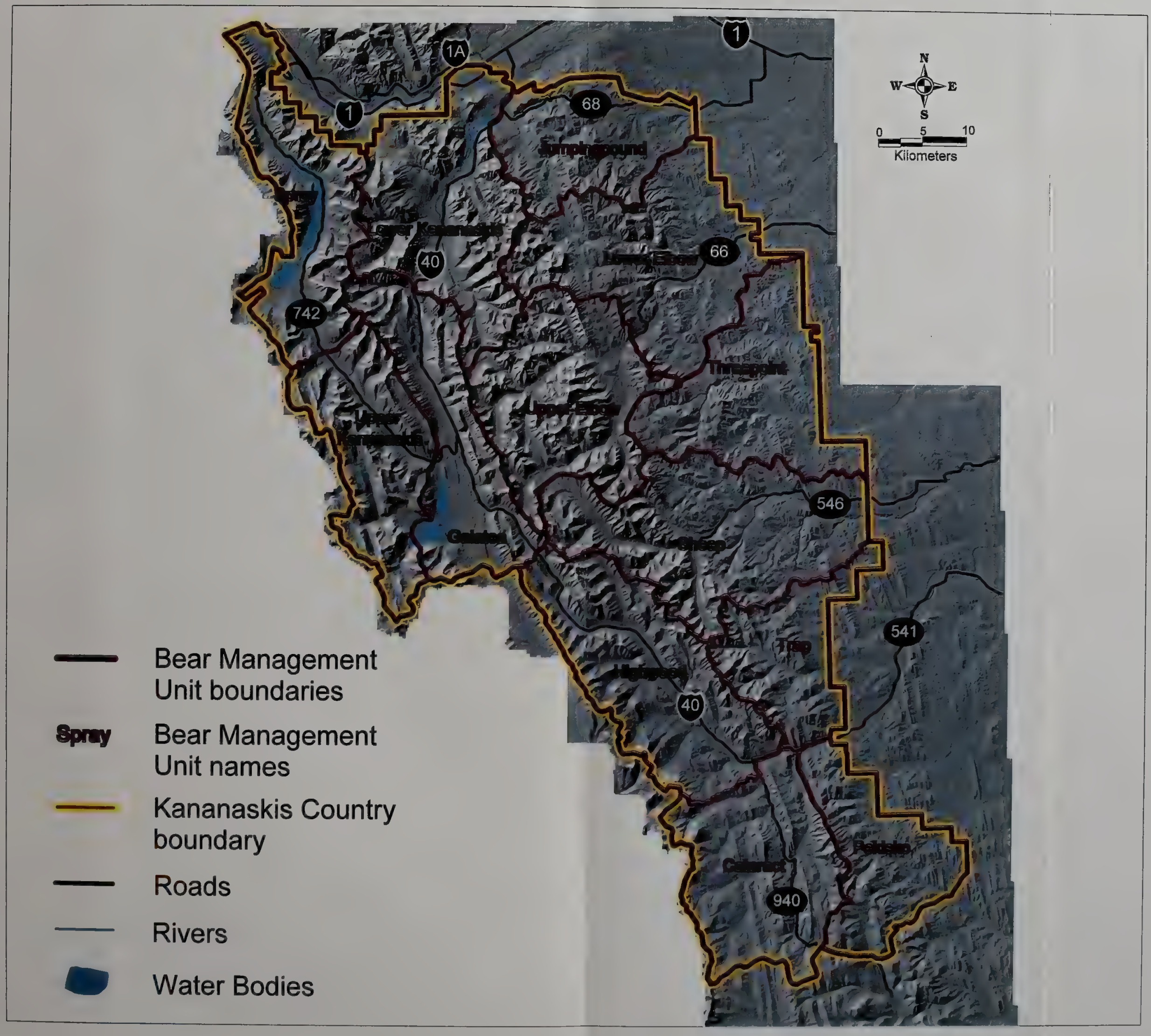

Map 4. Bear management units (BMUs) in Kananaskis Country. 

observation). South of Elbow Pass is the Highwood Pass, which opens into the Highwood River valley. These passes in the eastern portion of the Kananaskis lead into the foothills ecoregion. This is an area of very important habitat, especially in the winter due to the low accumulations of snow.

The western portion of Kananaskis Country, offers only a few corridors south of the Bow valley. Creation of the Spray Lakes Reservoir no doubt altered wildlife movements in this area, a point noted by Joe Kovachs, a Kananaskis-Spray Forest Ranger from 1940-53 (McCrory and Herrero 1982). Goat Creek, above Canmore, is used by animals to pass between the Smith-Dorrien and Spray River valleys. Even more important is the south end of the Spray Lakes Reservoir. This band of regenerating clearcuts, wetlands, and avalanche slopes affords good quality habitat for a host of species, and presents several options for movement from the Smith-Dorrien valley into Banff National Park, Mount Assiniboine Park, and several river valleys in British Columbia (Bryon Benn, personal observations; historical recollections of Joe Kovachs, Louis Kamenka Sr. and Harry Connolly in McCrory and Herrero 1982). Burstall Pass, about $5 \mathrm{~km}$ to the south, is a lesser used pass into the headwater lakes and alpine region of the Spray and Palliser Rivers. Grizzly bears use the North Kananaskis Pass (Bryon Benn, personal observation), and to a lesser extent, the South Kananaskis Pass, to move into the Palliser River valley (McCrory and Herrero 1982). About $30 \mathrm{~km}$ south of the Spray Lakes Reservoir, is another very important wildlife corridor, Elk Pass. This broad, low-elevation pass links the Smith-Dorrien and Kananaskis valley systems with the Elk River valley of British Columbia.

In the south end of Kananaskis Country, a few higher elevation passes offer passage between the Highwood and Elk River valleys. Of note, to the south of the impassable Elk Range, are Weary Creek Gap between Mount McPhail and Mount Muir, and Fording River Pass at the head of Baril Creek (McCrory and Herrero 1983). Similarly, a series of drainages provide movement corridors into the Oldman and Livingstone River valleys to the south of Kananaskis Country.

Providing habitat continuity and security for grizzly bears and other long ranging species is fundamental to the health of populations.

\section{HABITAT ASSESSMENT}

\section{Introduction}

\section{The nature of grizzly bear habitat}

Wildlife habitat has been defined as “...the physical and biological environment (including climate) that provides or detracts from the essentials of food, cover, and space that are needed by a population of animals for reproduction, maintenance and growth" (Stelfox 1991). In an area with very low levels of human development and activity, grizzly bear use of habitat corresponds to a large extent to the location of concentrations of seasonally favoured food sources (Stelmock 1981, Craighead and Mitchell 1982, Hamer and Herrero 1983). Ecological studies of grizzly bears in the Rocky Mountain 

National Parks (Russell et al. 1979, Hamer and Herrero 1983, Raine and Riddell 1991) have demonstrated that grizzly bears utilize certain key plant and animal foods seasonally, and shift their seasonal land use to areas where these foods occur in abundance.

Because of a combination of social and ecological requirements, grizzly bears need large areas of land or "space" on an annual and lifetime basis. Annual home ranges of individual adult grizzly bears in the Canadian Rocky Mountains average from 165 to 532 $\mathrm{km} 2$ for females and 644 to $1628 \mathrm{~km}^{2}$ for males (Russell et al. 1979, Hamer and Herrero 1983, Raine and Riddell 1991, Gibeau and Herrero 1997). This requirement for space also assumes that there is an equitable distribution of seasonally appropriate habitat within an annual or lifetime range. This concept of seasonal habitat equity is central to the development of habitat suitability models (Weaver et al. 1986).

\section{Habitat effectiveness and grizzly bears}

As human use of the landscape increases, access by grizzly bears to seasonal concentrations of important foods can be limited or blocked (Mace and Manley 1993, Mace et. al. 1996) or present a mortality risk (Mattson 1993). Even though a land area may produce abundant food supplies for grizzly bears because of some combination of inherent ecological conditions (e.g. climate, landform and soils), bears may not utilize the area because of high levels of sensory disturbance or mortality risk. This unwillingness of bears to utilize otherwise suitable habitat is termed effective habitat loss, and has been quantified in recent years through standardized measures of habitat effectiveness (Weaver et al. 1986, Gibeau 1995, Gibeau et al. 1996). Effective habitat loss is generally more severe in areas that allow hunting than it is in protected areas (Mace and Manley 1993, Mattson 1993). Related to this is a grizzly bear's need for habitat types that offer security in the form of cover. In hunted areas the importance of security cover becomes greater (Mattson 1993), and this is reflected in changes to disturbance coefficients in habitat effectiveness models for open versus closed vegetation cover areas (Weaver et al. 1986, USDA Forest Service 1990).

In this section of the report, we present and discuss the results of a grizzly bear habitat suitability and effectiveness assessment for Kananaskis Country.

\section{Methods}

For a discussion of the methodology for this assessment, see Appendix A (Methodologies; Habitat assessment).

\section{Results and discussion}

\section{Bear Management Units}

A total of 13 Bear Management Units (BMU) were delineated for Kananaskis Country (see Map 4). BMUs ranged in size from $206 \mathrm{~km}^{2}$ to $463 \mathrm{~km}^{2}$. Each unit was characterized by a particular assortment of physical elements and vegetation types and is located predominantly in the main or front ranges of the Rocky Mountains. Ecological 

conditions of each BMU are summarized in Appendix B (Ecological characteristics by Bear Management Unit).

\section{Habitat classification and mapping}

Five hierarchically-nested habitat maps were completed for the $5712 \mathrm{~km}^{2}$ Kananaskis Country region. Appendix C (Hierarchical land cover mapping for Kananaskis Country and region) provides examples of the first four levels of mapping, along with the associated map legend, and area analyses ${ }^{5}$. Level 4 mapping resulted in 122 recurring map units that were characterized by combinations of dominant vegetation/land cover (40 classes), elevation range (4 classes), aspect (3 classes) and slope angle (4 classes). The vegetation and topography of each Level 4 map unit is found in the legend for Map C-4 in Appendix C.

\section{Habitat suitability assessment}

A total of 1411 Level 1 field sampling plots were completed within the $5712 \mathrm{~km}^{2}$ study area that includes and surrounds Kananaskis Country (Map 4). These were detailed vegetation plots with percent cover measures of all vascular plants, ant capability estimates, hiding cover measures, and site conditions. All plots were entered into Microsoft ACCESS database software. Table D-1 in Appendix D (Habitat suitability assessment tables) summarizes the number of plots that were completed for each Level 4 habitat map unit in the Kananaskis Region study area. An average of 12.7 plots were completed per Level 4 habitat map unit, and ranged from 0 to 62 . Level 4 habitat units with low sample sizes were rare in the study area.

Table D-2 in Appendix D summarizes the results of the habitat suitability index models for each Level 4 habitat map unit. The model results display the submodel results for plant foods, ants and ungulates that contributed to the overall HSI (Habitat Suitability Index) values based on the seasonal formulas outlined above. Table D-3 presents the results of the raw and normalised habitat suitability values for Level 4 habitat map units once the overall HSI formulas were run. Table D-3 also presents the empirical hiding cover (HC) values from Level 1 sampling plots. High hiding cover values identify habitat types that offer the greatest security for bears.

\section{Habitats with high suitability}

Habitat types with the highest suitability values for grizzly bears during the "pre-berry" season (den emergence to July 15) included:

- moderately to steeply sloping shrublands in the Subalpine (USM3, USM4, USS5);

- riparian spruce and conifer-dominated mixed-wood forests in the Lower Foothills and Lower Subalpine;

- south to west facing, moderately to steeply sloping deciduous forest;

- treed clearcuts;

\footnotetext{
${ }^{5}$ Excluding the area analyses for the Level 4 land cover classification map. These very detailed data may be examined on request to the Eastern Slopes Grizzly Bear Project.
} 

- gently sloping pine mixed-woods in the Lower Foothills and Lower Subalpine; and

- steeply sloping, south to west-facing grasslands in the Subalpine.

Habitat types with the highest suitability values for grizzly bears during the "berry-andafter" season (July 15 to den entry) included:

- treed and shrub sapling clearcuts;

- moderately to steeply sloping south to west facing Subalpine shrublands;

- moderately to steeply sloping, south to west facing Lodgepole Pine forests and pine mixed-woods in the Lower Foothills and Lower Subalpine; and

- riparian Balsam Poplar and White Spruce forests in the Lower Foothills and Lower Subalpine.

\section{Seasonal distribution and abundance of high suitability habitat}

Maps 5 and 6 present the 10 classes of grizzly bear habitat suitability for Kananaskis Country and region, for the pre-berry and berry-and-after seasons, respectively. Notable concentrations of high suitability ( 8,9 and 10 ratings) habitat during the pre-berry season were found in the areas immediately south and north of Spray Lake; the Elk Pass area in the Galatea BMU; the Smith-Dorrien River valley in the Upper Kananaskis BMU; and on private lands between Bull Creek and the Highwood River east of Highway 541. High suitability habitat tends to cluster along most major river systems during the pre-berry season including the Kananaskis, Highwood and Bow River valleys. This is especially true for BMUs in the north-western Main Range portion of the study area that are comprised of a high percentage of barren rock (e.g. Spray, Galatea, Upper and Lower Kananaskis). Areas of high habitat suitability during the pre-berry season tend to be more extensive and evenly distributed in the Front Range BMUs (e.g. Threepoint, Pekisko). This is consistent with grizzly bear telemetry research findings that show spring and early summer movements of male bears to front range habitats (Russell et al. 1979, Carr 1989, Gibeau and Herrero 1996).

Patches of high suitability habitat were more localized during the berry-and-after season (Map 6). Notable areas of concentration of high suitability fall habitat included: the Odlum and Loomis Creek valleys and the southwest-facing slopes of the Highwood Range in the Highwood; the headwaters of Etherington Creek, Baril Creek, and the valley sides of Cummins and Lost Creek in the Cataract BMU; the Smuts Creek valley of the Spray BMU; the Cox Hill Creek/Jumpingpound Creek area of the Jumpingpound BMU; the upper extent of Threepoint Creek in the Threepoint BMU; and the Moose Mountain Creek/Jumpingpound Mountain area of the Lower Elbow BMU. High to very high suitability berry-and-after season habitats are generally limited in eastern portions of the Front Range BMUs. 



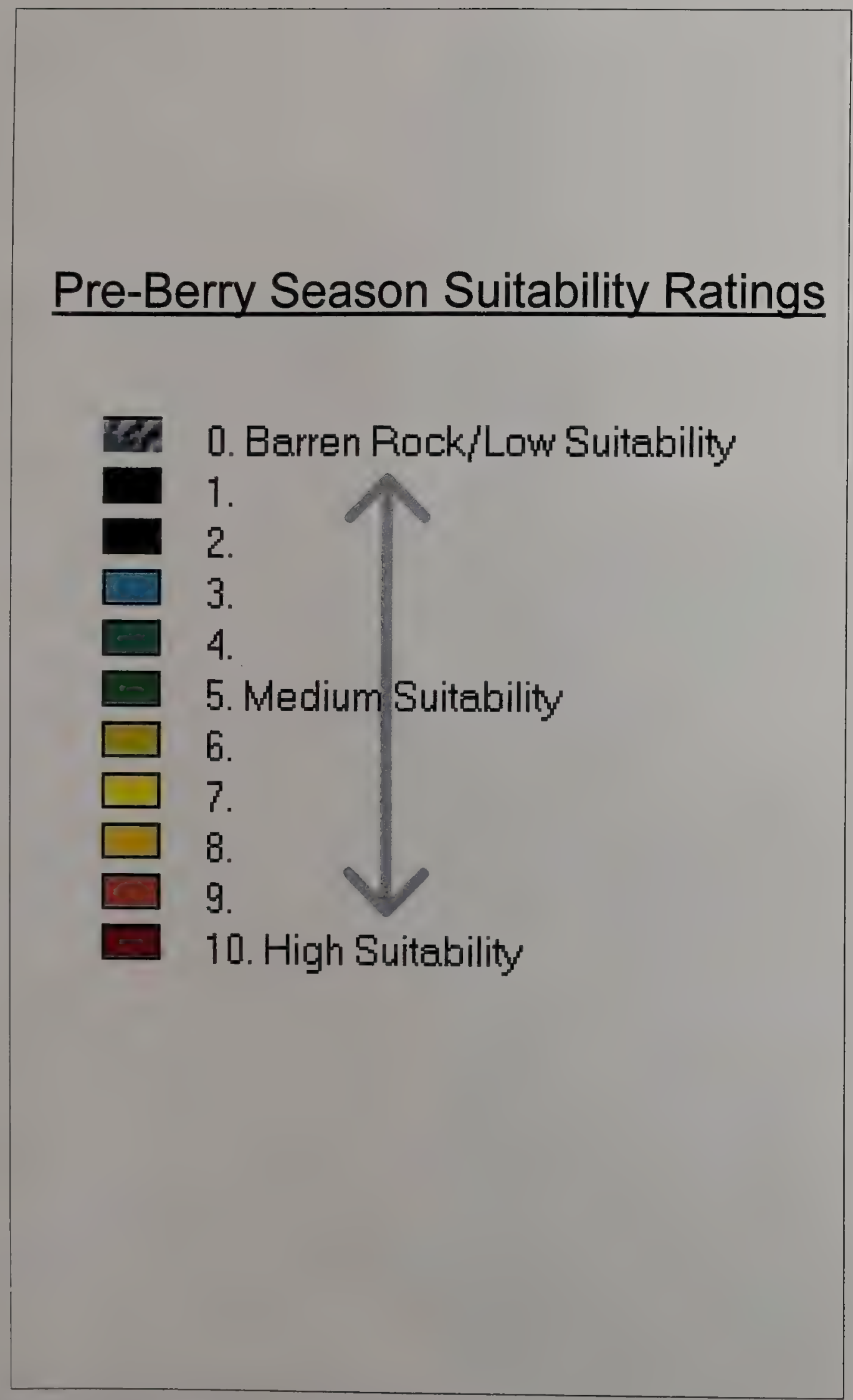

Grizzly Bear Status in K-Country * ESGBP

Map 5. Grizzly bear habitat suitability (quality) mapping for Kananaskis Country: Pre-berry season.

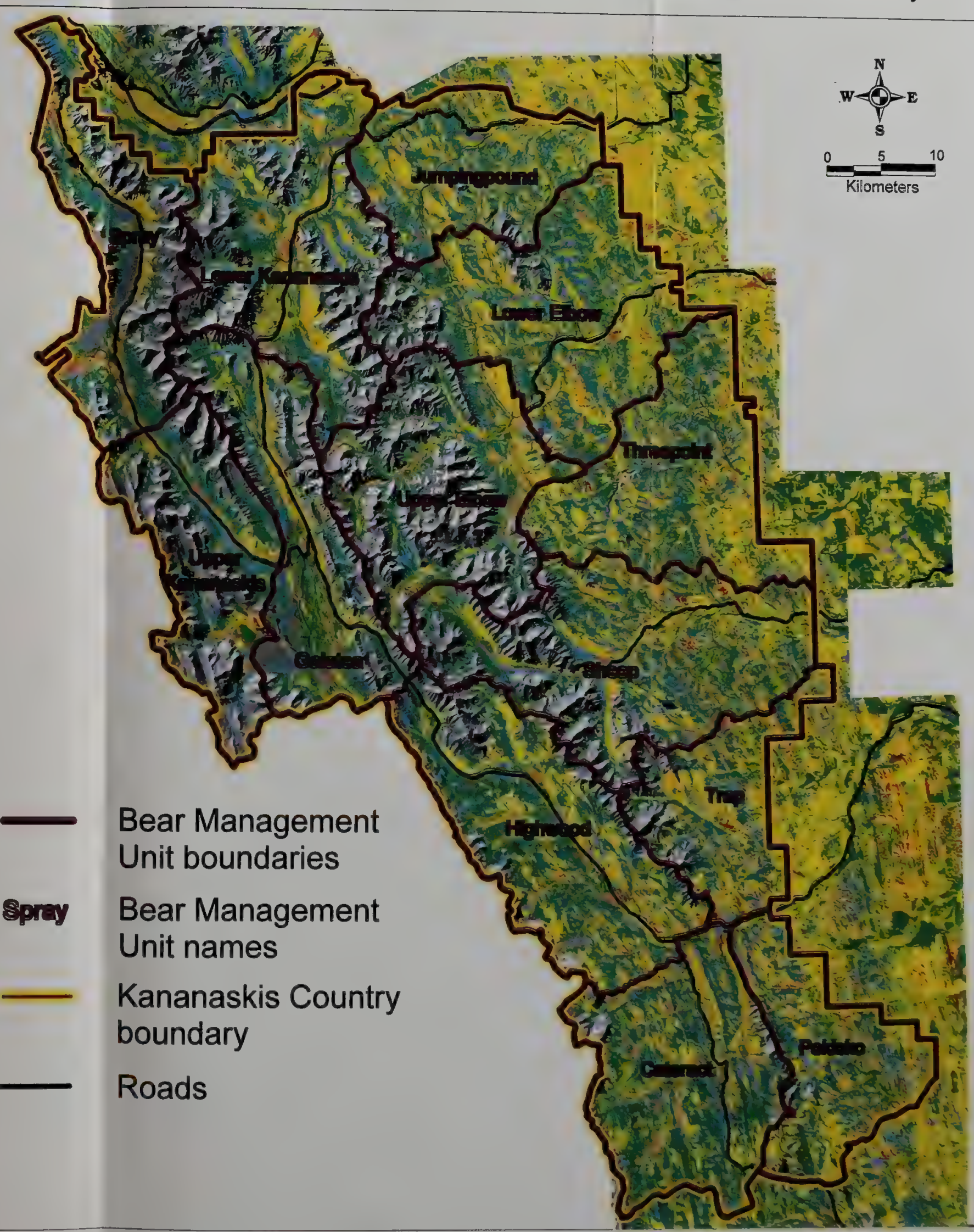



Berry-and-after season Suitability Ratings

[R] Barren Rock/Low Suitability

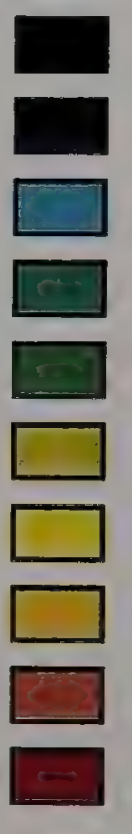

1.

2.

3.

4.

5. Medium Suitability

6.

7.

8.

9.

10. High Suitability
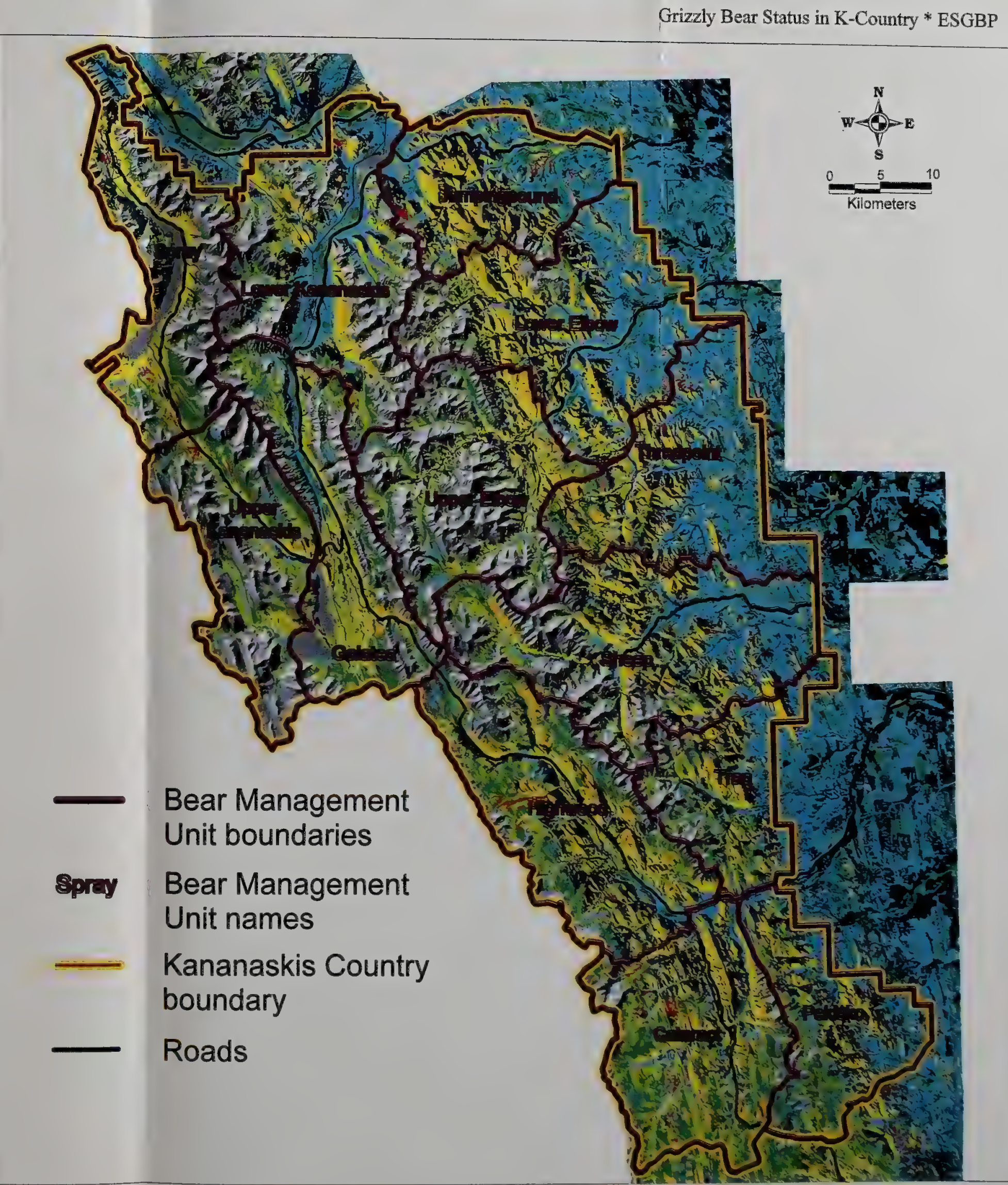

Tables 3 and 4 summarize the percentage of each class of habitat suitability (1 to 10) that occurs in each BMU for the pre-berry and berry-and-after seasons, respectively. This summary clearly shows that BMUs found in the eastern Front Ranges of Kananaskis Country support the highest relative percentages of high to very high suitability (classes 8 , 9 and 10) grizzly bear habitat during the pre-berry season. These include the Jumpingpound, Threepoint, Trap, Lower Elbow and Pekisko BMUs. The large supply of south to west facing Aspen and Lodgepole Pine forests, low elevation grasslands, and riparian forests in these eastern BMUs contribute to this finding.

BMUs in the south-western portion of Kananaskis Country (Highwood, Cataract) tended to support the highest suitability grizzly bear habitat during the berry-and-after season (Table 4). This was attributable mainly to an abundance of south to west facing Lodgepole Pine forests and treed and shrub-sapling clearcuts, both of which produce good buffaloberry and blueberry crops. Also more common in the Highwood and Cataract BMUs were moderately to steeply sloping south to west facing upper subalpine shrublands USM3). This habitat type was found to produce extensive root crops (see Table D-2 in Appendix D).

\section{Habitat effectiveness in Kananaskis Country}

Habitat effectiveness values were calculated for 13 Bear Management Units in Kananaskis Country (Table 5). Derived from these single-number effectiveness values for BMUs are Maps E-1 to E-13 (Appendix E: Potential and realized habitat suitability maps by bear management unit) which illustrate the habitat suitability before (potential) and after (realized) the overlay of disturbance features.

\section{Table 5. Habitat effectiveness values for 13 bear management units (BMUs) in Kananaskis Country.}

\begin{tabular}{|lcclc|}
\hline $\begin{array}{c}\text { Bear management } \\
\text { unit (BMU) }\end{array}$ & $\begin{array}{c}\text { Habitat } \\
\text { effectiveness } \\
\text { value }\end{array}$ & & $\begin{array}{c}\text { Bear management } \\
\text { unit (BMU) }\end{array}$ & $\begin{array}{c}\text { Habitat } \\
\text { effectiveness } \\
\text { value }\end{array}$ \\
${$\cline { 1 - 2 }$} }$ & 0.75 & & Upper Elbow & 0.76 \\
Cataract & 0.81 & & Galatea & 0.49 \\
Trap & 0.82 & & Upper Kananaskis & 0.65 \\
Highwood & 0.76 & & Jumpingpound & 0.71 \\
Lower Elbow & 0.66 & & Lower Kananaskis & 0.69 \\
Sheep & 0.79 & & Spray & 0.57 \\
Threepoint & 0.75 & & & \\
\hline
\end{tabular}

Habitat effectiveness values ranged from $49 \%$ to $82 \%$ and averaged $71 \%$. Gibeau et al. (1996) calculated habitat effectiveness values of from $46.6 \%$ to $97.9 \%$ (average $=83.2 \%$ ) for 40 BMUs in Banff National Park. The Banff model applied the same zones of 


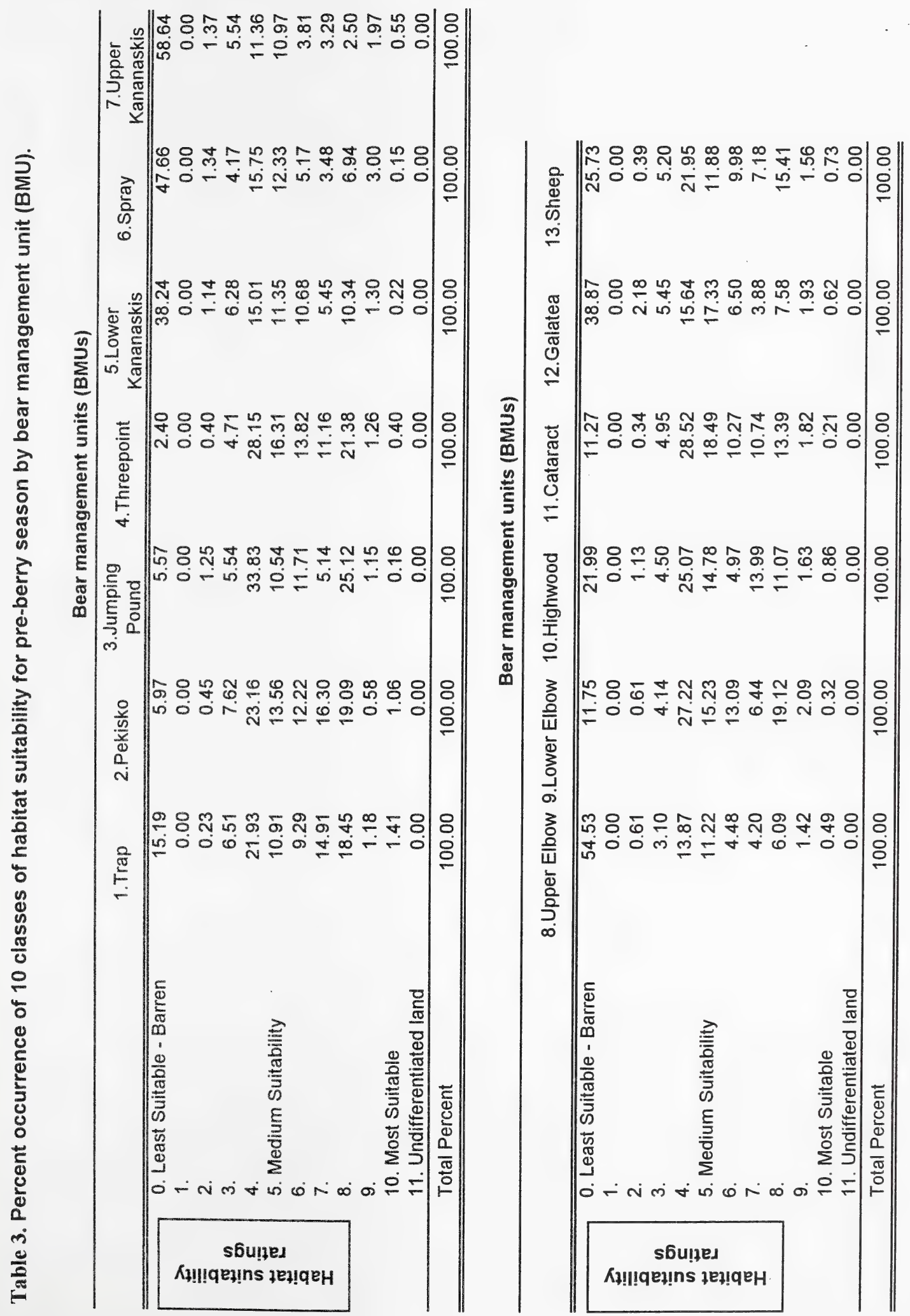




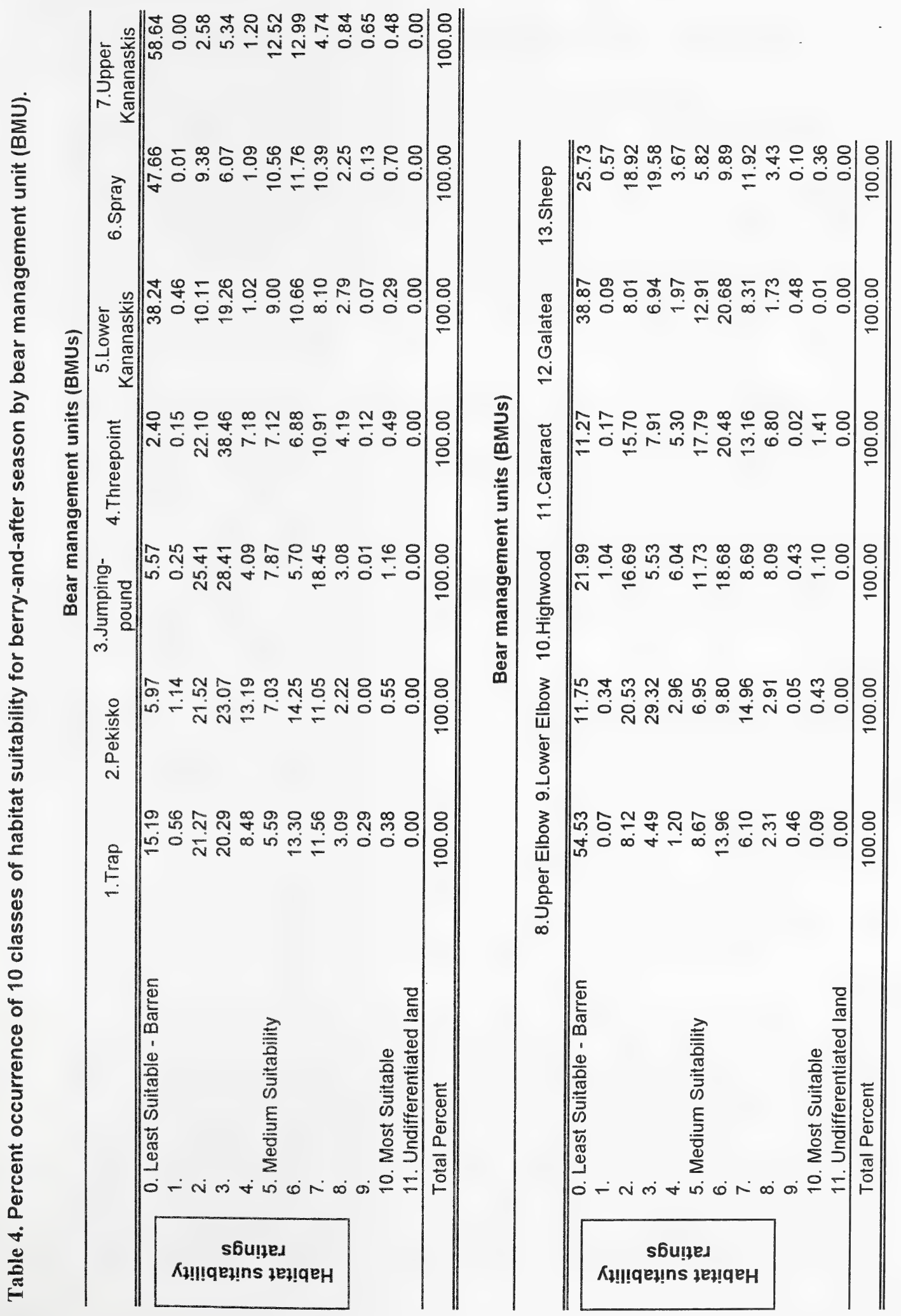

influence and disturbance coefficients as the Kananaskis model, although the habitat mapping and suitability approaches differed somewhat.

The lowest habitat effectiveness values (below 70\%) were found in BMUs in the western Main Range portions of Kananaskis Country. These BMUs included Galatea (49\%), Spray (57\%), Upper Kananaskis (65\%). These three BMUs all have primary transportation corridors such as Highway 40 and the Smith-Dorrien Road. The exception was the Lower Elbow BMU (66\%) which is located in the eastern Front Ranges. BMUs with highest habitat effectiveness values were Trap (82\%), Cataract (81\%), Sheep (79\%), Highwood (76\%) and Upper Elbow (76\%). These high-habitat effectiveness BMUs are affiliated with the inter-mountain ranges of the southern and central portions of Kananaskis Country and tend not to support primary and major secondary roads with relatively high levels of traffic.

The paired maps of potential and realized habitat suitability shed light on the nature of habitat effectiveness loss in the various BMUs. For example, the facility zone of the Galatea BMU is dominated by a high proportion of high quality berry-and-after season potential habitat. The overlay of multiple overlapping linear and point development features in this area of concentrated human use results in the generation of large tracts of significantly disturbed habitat from a realized habitat perspective. Similarly, in the same BMU, areas of very high and high suitability habitat along the Kananaskis and Spray River valleys (Spray, Upper and Lower Kananaskis BMUs) have been effectively lost according to the model as a result of the effects of Highway 40, the Smith-Dorrien Highway, and associated point developments.

The Trap BMU offers a slightly different perspective on effective habitat loss. In this $\mathrm{BMU}$ there is no major transportation corridor, although there are secondary ranch access roads and associated homesteads. As a result there are fewer disturbance zones and lower-level disturbance coefficients, hence resulting in less loss of habitat effectiveness. This is also the pattern for a number of other Front Range BMUs, notably the Sheep and Threepoint. In these eastern BMUs, it can be noted that much of the very high and high suitability habitat is found in upland sites, versus valley bottom areas for Main Range BMUs such as Spray, Upper and Lower Kananaskis and Galatea. Loss of habitat effectiveness in Front Range BMUs could be less significant in terms of grizzly bear use of the area than in other areas where high suitability habitat is concentrated in valley bottoms and associated valley slopes.

The relationship between habitat effectiveness values for BMUs and grizzly bear landscape use or population status has not been empirically determined for Kananaskis Country. Relationships to date are based on expert opinion regarding documented grizzly bear response and mortality associated with human activities and developments in Montana and Wyoming (USDA Forest Service 1990). Gibeau (1995) noted that CEMs (Cumulative Effects Models) in the United States suggest that habitat effectiveness values of less than $70-80 \%$ could exceed the grizzlies' threshold of acceptance of disturbance, and lead to abandonment of the area for other than occasional foraging. Many other factors have the potential to affect the relationship between habitat effectiveness and landscape use by grizzly bears. Potentially affected factors include habituation of bears, 

habitat suitability, long term mortality, and traditional habitat use. Sorting out these factors is one of the mandates of the Eastern Slopes Grizzly Bear Project (Herrero et al. 1996). One use of habitat effectiveness mapping is in providing quantitative comparisons of human use types and levels between BMUs in different administrative land areas.

\section{GRIZZLY BEAR SECURITY AREAS IN KANANASKIS COUNTRY}

(this section is mostly derived from a recent paper by Gibeau and Herrero In press)

\section{Introduction}

Researchers recognize that human access is one of the most influential factors affecting grizzly bear habitat security. Although grizzly bear mortality can be regulated and influenced by changes in human attitudes, it seems unlikely that humans will generally tolerate much contact with an animal like the grizzly bear, that is a direct competitor for space and foods (Mattson 1990) and a potential hazard (Herrero 1985). Thus, there is a strong case for preserving areas were grizzly bears will be relatively secure from encounters with humans; where bears can meet their energetic requirements while at the same time choosing to avoid people (Mattson 1993). Such security areas would foster the wary behaviour in grizzly bears that most managers consider desirable (Mattson 1993).

Since the development of cumulative effects models (CEM) for grizzly bears in the mid1980s (Weaver et al. 1987, USDA Forest Service 1990), there have been significant advances in understanding the management of grizzly bears and substantial accumulation of empirical data about their ecology (see Gibeau et al. 1996, Mattson et al. 1996, Weaver et al. 1996, Mace and Waller 1997, and references therein). However, the CEM does not explicitly address the need for habitat security whereby bears maintain wary behaviour, nor does it assess the value of small areas left between zones of human disturbance. To address this problem, Mattson (1993) developed the idea of micro-scale security areas where bears can forage for 24-48 hours safe from human disturbance. Micro-security areas include a core zone (based on foraging radius) surrounded by a disturbance-free buffer zone (based on displacement distances).

The Interagency Grizzly Bear Committee (IGBC) in the United States has endorsed an approach for providing habitat security for grizzly bears at the larger scale of Bear Management Units (Puchlerz and Servheen 1994). Based upon research by Mace and Waller (1997), interagency managers in the Northern Continental Divide grizzly bear ecosystem in north-west Montana have specified that $>60-67 \%$ of BMUs be in secure status for several years to provide long-term security for adult female grizzly bears. Security areas help to reduce the incidence of poached bears, bears killed out of selfdefence, and bears killed by management agencies because of unacceptable behaviour. Grizzly bears in Yellowstone National Park have aggregated in areas managed explicitly for habitat security.

We modelled security areas in Kananaskis Country and the Central Canadian Rocky Mountains (Map 7), predicting where adult female grizzly bears will have a low probability of encounter with people based on an average daily feeding radius established from radio telemetry data. 



\section{Methods}

For a discussion of the methodology for the security area analysis, see Appendix A (Methodologies; Grizzly bear security areas).

\section{Results}

Analysis of 153 daily movement episodes from 14 wary (non-habituated) adult female grizzly bears produced a mean daily movement distance of $3.4 \mathrm{~km}$ (range $0.2-15.0 \mathrm{~km}$, $\mathrm{SE}=.22 \mathrm{~km}$ ). Subsequently, the calculated average daily foraging radius was $1.7 \mathrm{~km}$ with a $9.0 \mathrm{~km}^{2}$ minimum daily area requirement.

Removal of rock, ice, water, and areas of bare soil from the analysis as well as an elevation cut of areas greater than $2400 \mathrm{~m}$ delineated areas available for grizzly bears. Forty two percent of the National Park landscape was unsuitable for foraging for grizzly bears. This contrasts sharply with only $10 \%$ unsuitable on Alberta multiple use lands, 24\% unsuitable in Alberta's Kananaskis Country, and 27\% unsuitable on British Columbia provincial lands (Figure 3, Map 8).

Application of a minimum daily area requirement of $9.0 \mathrm{~km}^{2}$ based on an adult female's daily foraging radius defines security areas and zones of human influence for each jurisdiction in the Central Canadian Rocky Mountains (Figure 3). Alberta's Kananaskis Country, with an intensive recreation mandate, had the greatest percentage of its land base (38\%) within a zone of human influence. Alberta multiple use lands follow closely behind with $32 \%$ within a zone of human influence, British Columbia provincial lands have $25 \%$, and National Parks $17 \%$. The percentage of land base where adult female grizzly bears will have a low probability of encounters with people (secure) is therefore a function of the amount of unsuitable land and the extent of high human influence.

Alberta multiple use land, with only $10 \%$ unsuitable land and $32 \%$ high human influence contrasts with the National Parks with $42 \%$ unsuitable and only $17 \%$ within high human influence. 



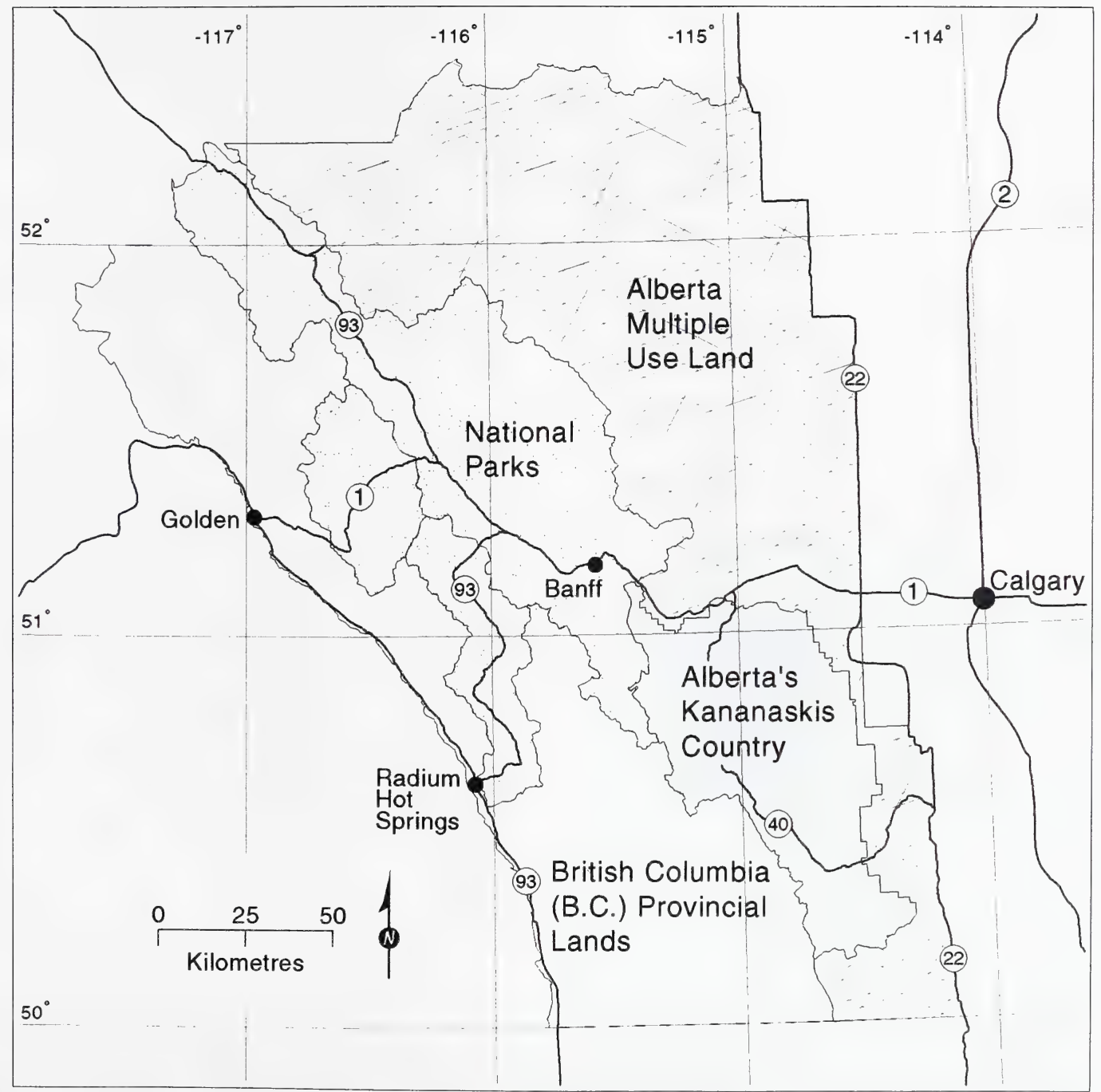

Map 7. The Central Canadian Rocky Mountains divided into 4 major government jurisdictions: (1) National Parks including, Banff, Yoho, and Kootenay; (2) British Columbia provincial lands, (3) Alberta multiple use lands, and (4) Alberta's Kananaskis Country. 



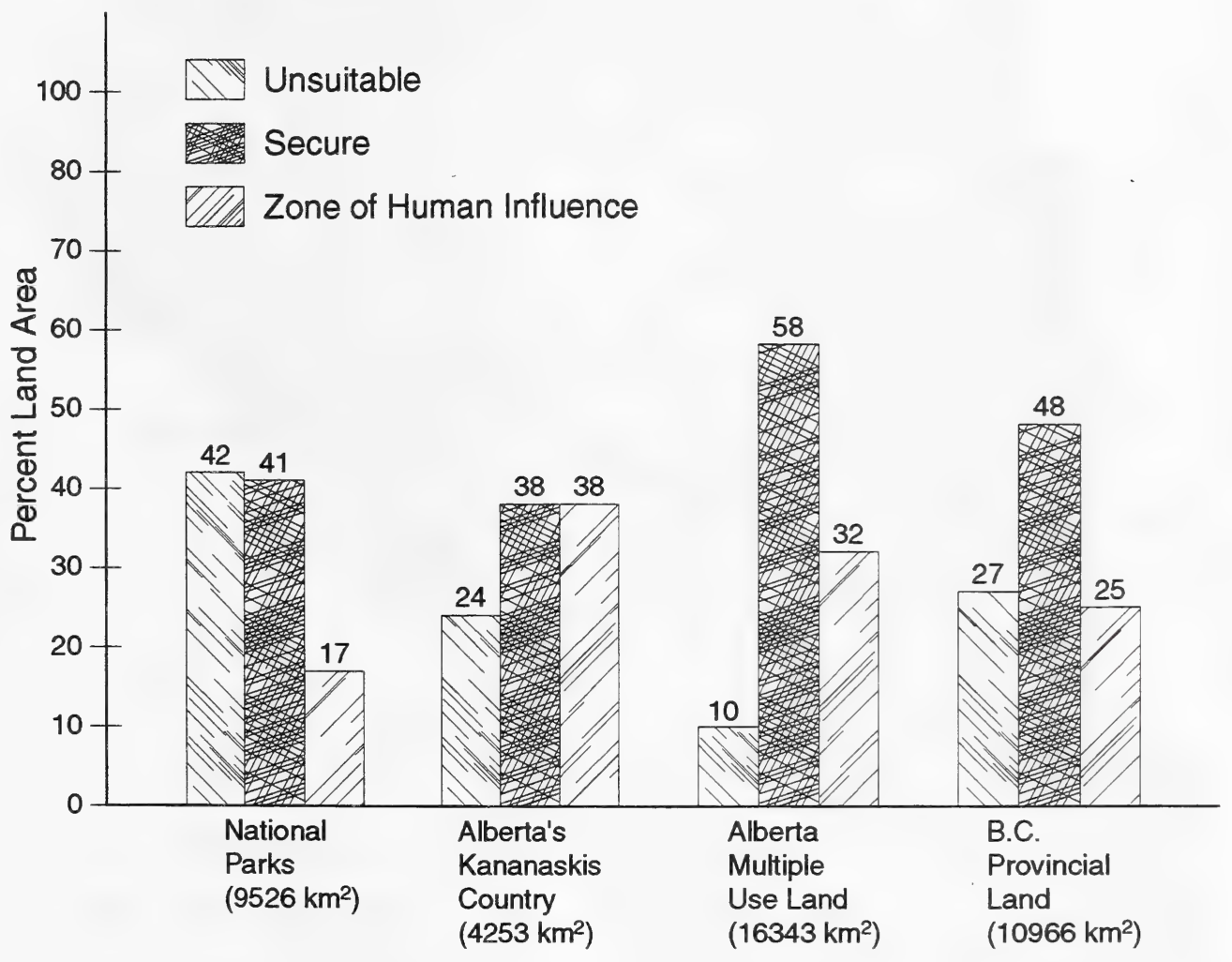

Figure 3. Percent of the land base in security area, unsuitable landscape, and land within the zone of human influence for 4 major government jurisdictions in the Central Canadian Rocky Mountains. 



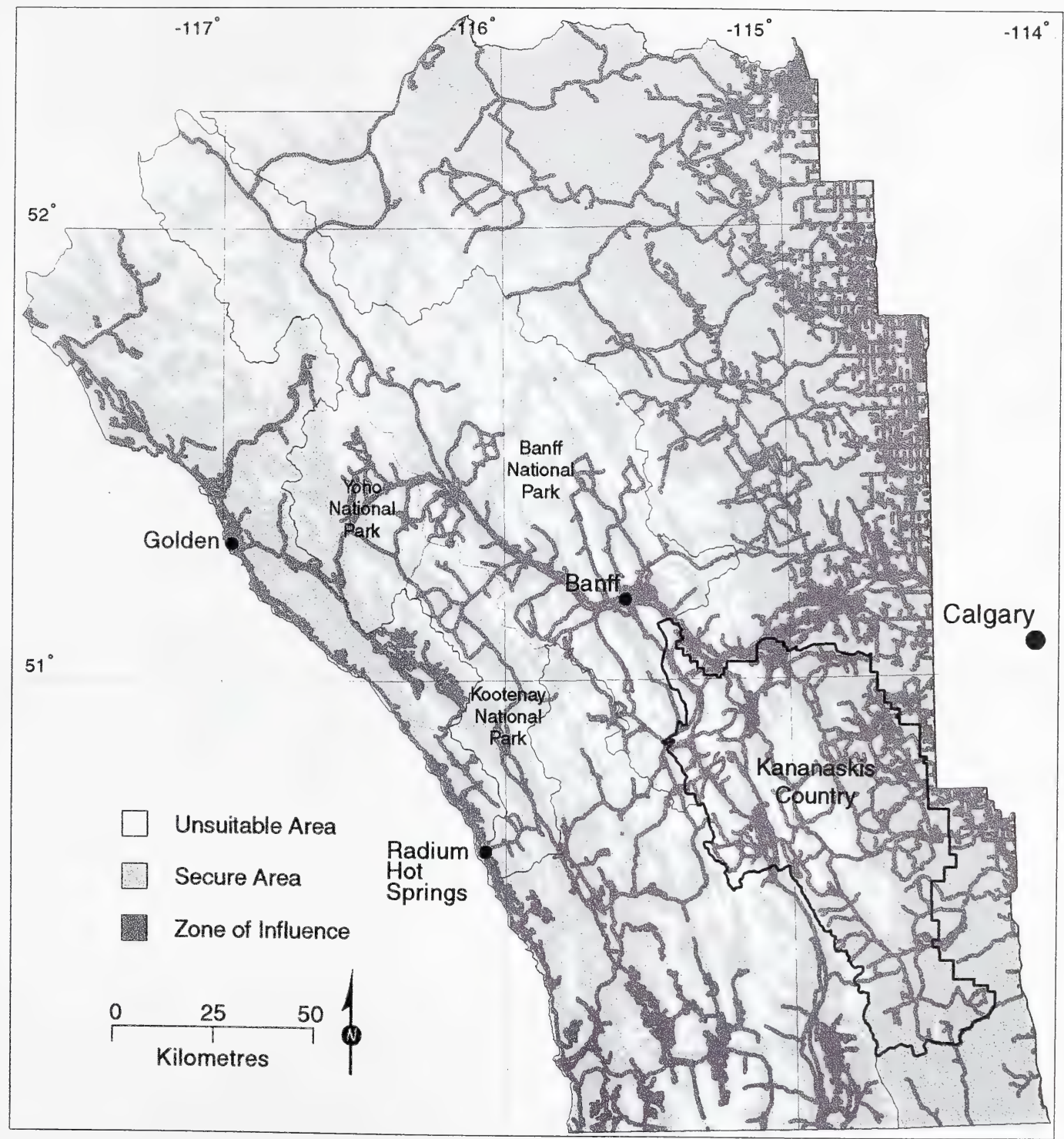

Map 8. The land base of 4 major government jurisdictions in the Central Canadian Rocky Mountains in security area, unsuitable landscape, and land within the zone of human influence. 

Both forecasting into the future and reconstruction of past human use for the two most intensively developed jurisdictions, Kananaskis Country and Banff National Park, demonstrate progressive apparent loss of security areas starting with the 1950's, through the present, and into the future (Figure 4). The average size of secure habitat patches in Kananaskis Country ranged from $364 \mathrm{~km}^{2}$ historically, to $38 \mathrm{~km}^{2}$ currently, and finally 29 $\mathrm{km}^{2}$ in the future. Corresponding to the decrease in patch size was an increase in the number of patches from 8 historically, through 43 currently, to 47 in the future. The same pattern existed throughout Banff National Park. Fragmentation and insularization of habitat within both jurisdictions was evident and along with that a loss in the ability to foster the wary behaviour in grizzly bears that most managers consider desirable.

Across our sample of 20 adult female grizzly bears, an average of $44 \%$ (range 12-79\%, $\mathrm{SE}=4.3 \%$ ) of the land base within a home range was considered secure (Table 6).

Unsuitable land averaged $32 \%$ and high human influence averaged $24 \%$ of a home range. Bears with the highest degree of human influence within their home range tended to have the least security (Map 9, for example). The 3 most affected bears (\#24, 26, 47) all had home ranges totally within Kananaskis Country. Several bears had lower than average security despite average or lower than average human influence due to a high percentage of unsuitable land within their home range (Map 10, for example). The 3 most affected bears in this case (\# 18, 36, 41) all had home ranges totally within Banff National Park. Bear \#47 had low security within her home range in the Kananaskis Lakes area due to a combination of a high percentage of unsuitable land and a high degree of human influence (Map 11).

The percentage of the land base in security area was negatively correlated with the percent of unsuitable land (Pearson's $r=-836, \mathrm{P}<0.01$ ), percent of the land within the zone of human influence (Pearson's $r=-.704, \mathrm{P}<0.01$ ), and $\log _{n}$ of home range size (Pearson's $r=-.499, \mathrm{P}<0.05)$. Regressions of the percent of the land base in security area against both the percent of unsuitable land $\left(F=41.74, \mathrm{r}^{2}=0.70, \mathrm{P}<0.0001\right)$ and percent of the land within the zone of human influence $\left(\mathrm{F}=17.73, \mathrm{r}^{2}=0.50, \mathrm{P}<0.0005\right)$ were highly significant (Figure 5). Regression analysis depicted a weak relationship between the percent of the land base in security area against the $\log _{n}$ of home range size $\left(\mathrm{F}=5.97, \mathrm{r}^{2}=0.25, \mathrm{P}<0.025\right)$.

\section{Discussion}

Our results quantitatively characterize grizzly bear habitat at the landscape level for the Central Canadian Rocky Mountains. This area supports a grizzly bear population which we assume has a significant degree of genetic exchange within it, and some degree of isolation from populations north and south. Four major, different land use jurisdictions are found in the area. Each has a unique land base, different general management policies, and different grizzly bear management. A large percentage (42\%) of the land surface area of one jurisdiction, the combined national parks (Banff, Kootenay and Yoho) in our study area, is unsuitable for grizzly bear foraging, primarily because it is composed of rock and ice. This is unfortunate because it has been assumed that these 



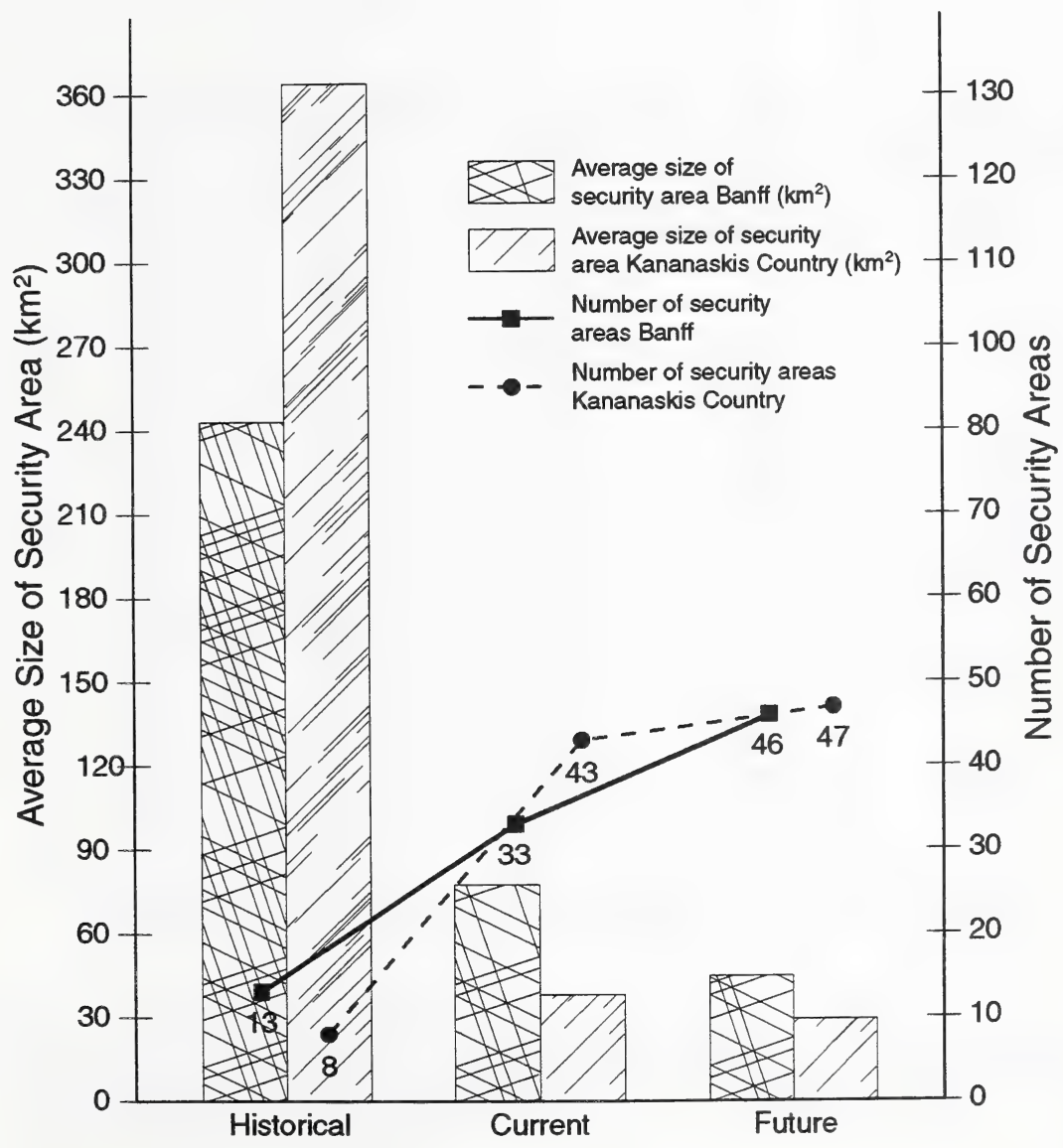

Figure 4. Time series analysis of grizzly bear security areas for Kananaskis Country and Banff National Park. 



\begin{tabular}{ccccc}
\hline $\begin{array}{c}\text { Bear } \\
\text { ID }\end{array}$ & $\begin{array}{c}\text { Home Range } \\
\text { Km2 }\end{array}$ & $\begin{array}{c}\% \\
\text { Unsuitable }\end{array}$ & $\begin{array}{c}\% \\
\text { Secure }\end{array}$ & $\begin{array}{c}\% \\
\text { Human Influence }\end{array}$ \\
\hline 17 & 147 & 19 & 40 & 41 \\
18 & 169 & 54 & 22 & 24 \\
24 & 239 & 40 & 13 & 48 \\
26 & 476 & 31 & 25 & 44 \\
28 & 363 & 28 & 55 & 17 \\
30 & 285 & 18 & 53 & 29 \\
31 & 131 & 23 & 43 & 34 \\
32 & 414 & 36 & 32 & 32 \\
33 & 197 & 30 & 39 & 31 \\
35 & 57 & 24 & 60 & 16 \\
36 & 753 & 46 & 30 & 24 \\
37 & 1016 & 35 & 32 & 33 \\
40 & 227 & 37 & 50 & 14 \\
41 & 182 & 49 & 39 & 12 \\
42 & 145 & 27 & 66 & 6 \\
44 & 365 & 24 & 67 & 9 \\
46 & 310 & 41 & 40 & 19 \\
47 & 272 & 44 & 12 & 44 \\
71 & 123 & 23 & 76 & 1 \\
74 & 57 & 16 & 79 & 5 \\
\hline
\end{tabular}

Table 6. Percent of the land base in security area, unsuitable landscape, and land within the zone of human influence for $\mathbf{2 0}$ adult female grizzly bears in the Central Canadian Rocky Mountains. 



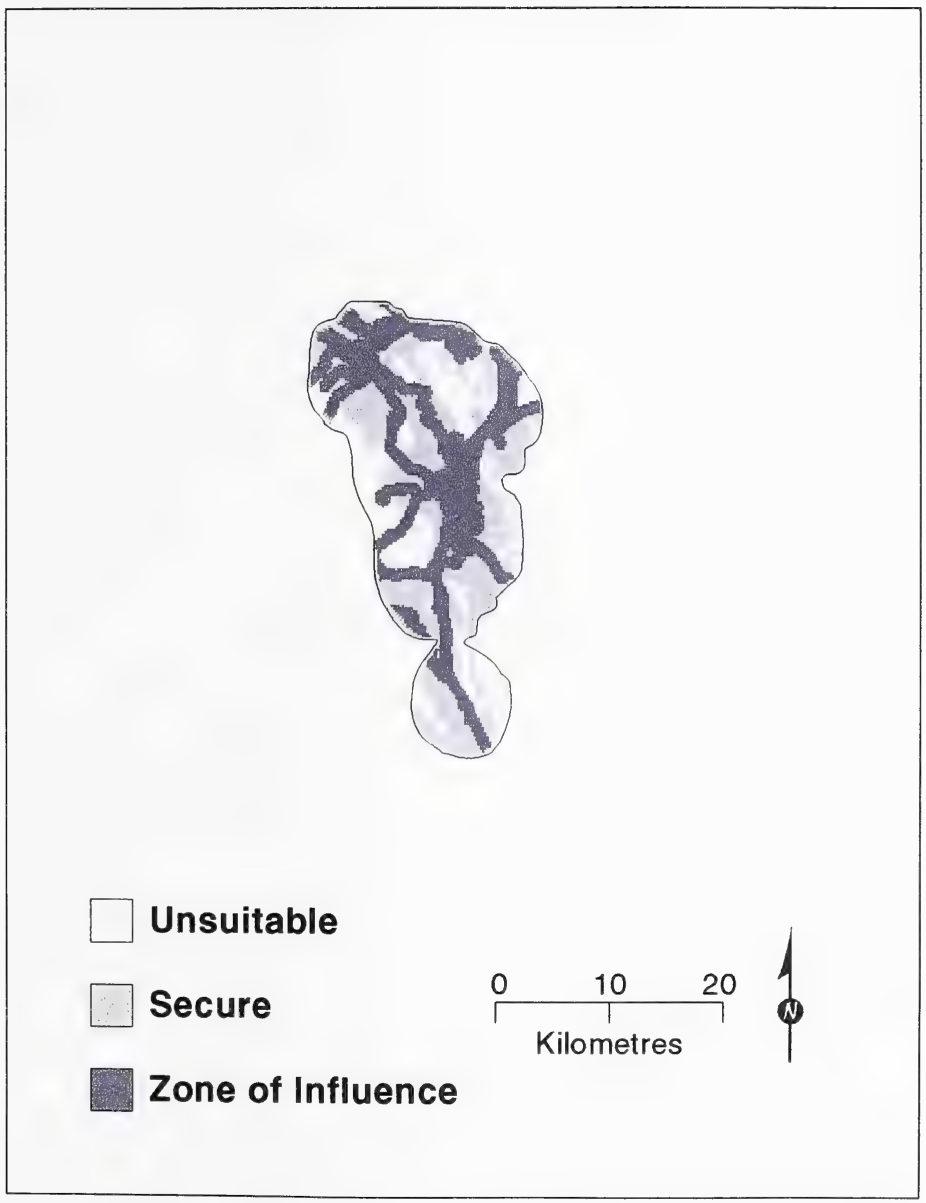

Map 9. Home range of female grizzly bear \#26 divided into secure area, unsuitable landscape, and zone of human influence. 



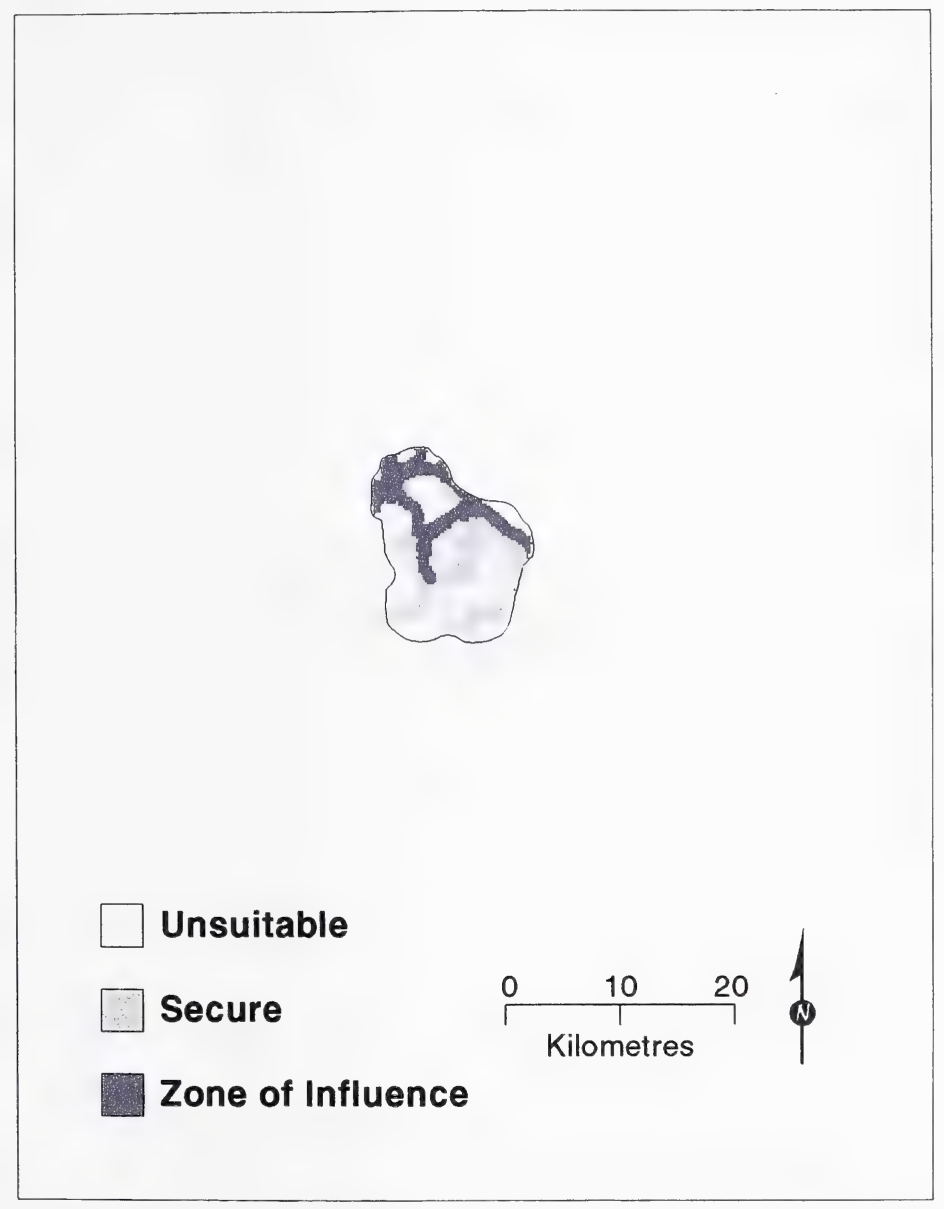

Map 10. Home range of female grizzly bear \#18 divided into secure area, unsuitable landscape, and zone of human influence. 



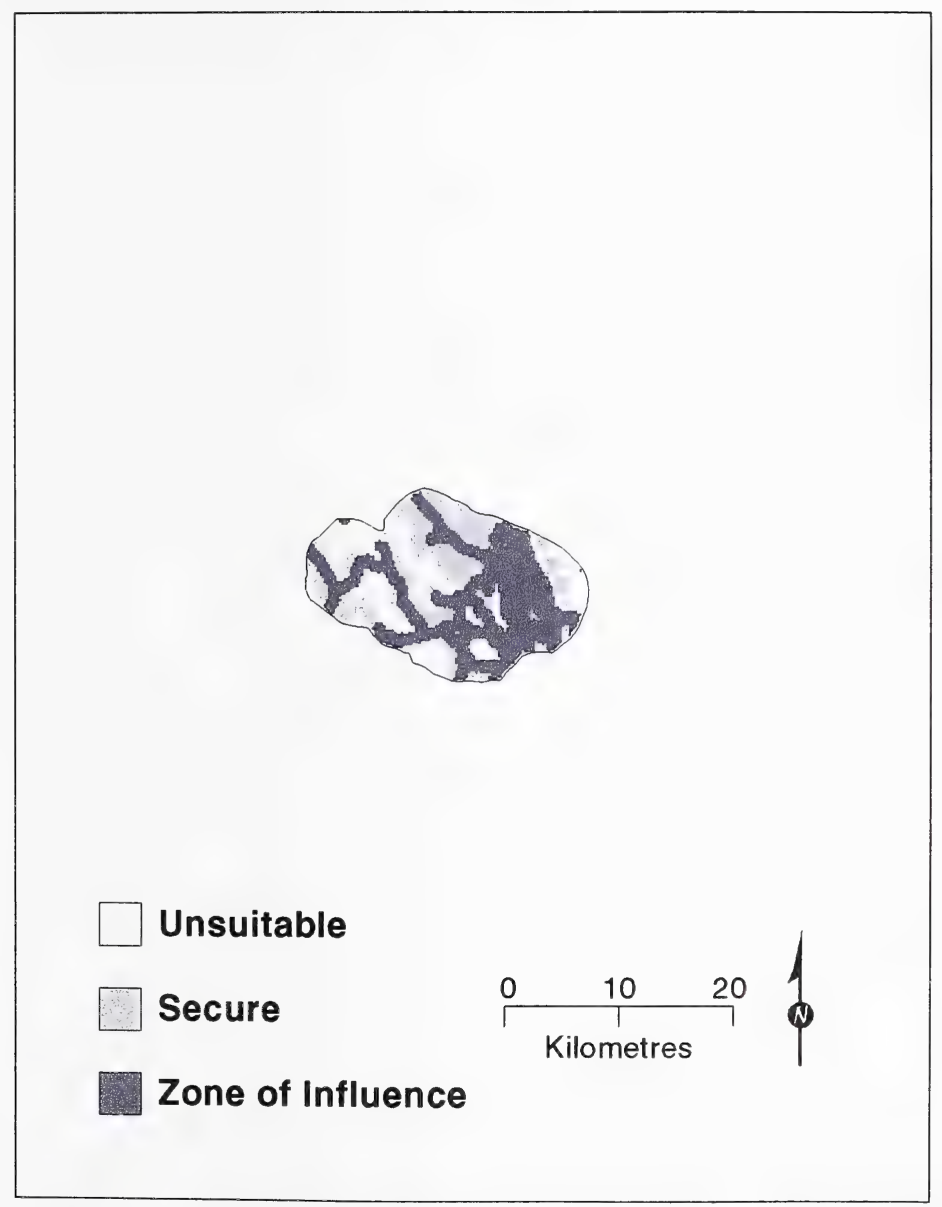

Map 11. Home range of female grizzly bear \#47 divided into secure area, unsuitable landscape, and zone of human influence. 


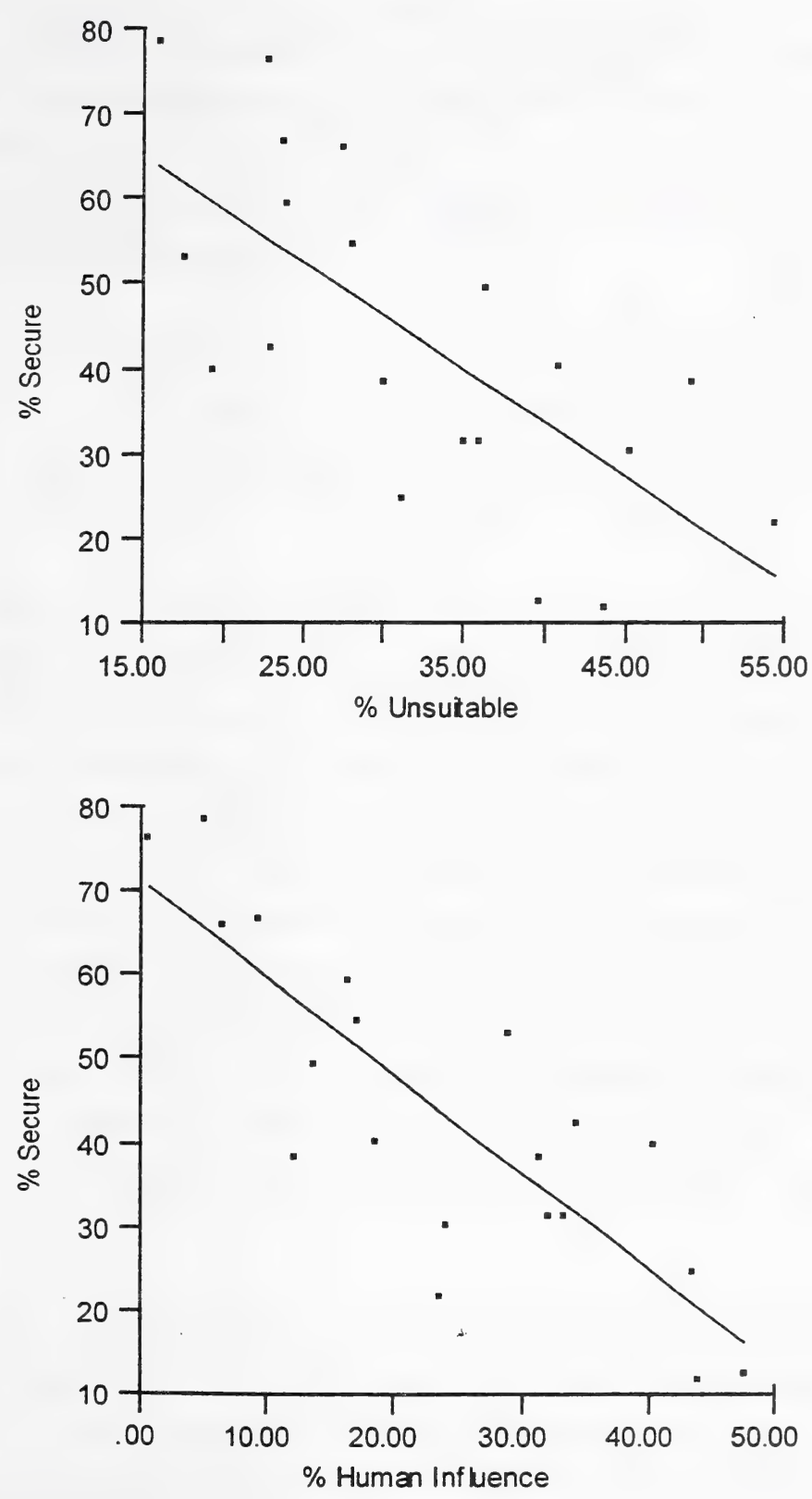

Figure 5. Regressions of the percent of the land base in security area against the percent of unsuitable land, and percent of the land within the zone of human influence for grizzly bears in the Central Canadian Rocky Mountains. 

national parks form productive core refugia for difficult to maintain species such as grizzly bears. Caughley (1994) commented on this phenomenon stating that species in trouble end up not in the habitat most favourable to them, but in the habitat least favourable to the agent of decline. In the Alberta multiple use lands portion of the Central Canadian Rocky Mountains, the percentage of unsuitable land is much less $(10 \%)$, indicating more productive land. However, conflicts with multiple human uses are greater here and are predicted to increase.

The concept of secure habitat, an area where an adult female grizzly bear can meet its daily foraging needs with a low probability of disturbance by people, is central to our research. Mattson et al. (1992) found that adult female grizzly bears with access to secure habitat maintained desirable wary behaviour, had low probabilities of becoming habituated or food-conditioned, and had significantly less mortality than did non-wary adult females.

Our results characterize habitat security at the adult female grizzly bears' home range level, and on average at the landscape level. Across our sample of 20 adult female bears throughout the region, an average of $44 \%$ of the home range was found to be secure. All female bears in Kananaskis Country (\# 24, 26, 31, 37, 47) fell below the average. The largest percentages of secure habitat by jurisdiction were in Alberta multiple use land and British Columbia provincial land. Only Alberta multiple use land, with 58\% secure habitat, reached or exceeded the $57 \%$ level considered to be adequate security by Mattson (1993). None reached target levels of 60-67\%, these being based on research by Mace and Waller (1997) and set by interagency managers for the Northern Continental Divide grizzly bear ecosystem in north-west Montana. Security levels for Alberta multiple use land will probably decrease as resource and other development activities proceed. Although Banff National Park has less secure habitat, it is probably more predictable into the future, and recent policy changes project modest increases in security (Parks Canada 1997). Kananaskis Country has the least percentage of land as secure habitat, and the largest percentage in the zone of human influence. Because this area is also dedicated to maintaining all wildlife populations, conflict of objectives occurs, and could increase.

We demonstrated that habitat security was positively correlated with the percentage of land available (potentially productive habitat) and negatively correlated with the extent of the zone of human influence. Having a large percentage of productive land within a home range appears to have increased the odds that a reasonable portion of it was secure. In home ranges where there was a lot of unsuitable habitat there was less productive land potentially available to meet security needs.

These results give quantitative substance to the proposition that grizzly bears in and around Kananaskis Country exist in one of the most human-influenced landscapes where they still survive. The habitat effectiveness component of the Cumulative Effects Model as applied to Banff, Yoho, and Kootenay National Parks also demonstrated this (Gibeau 1998). The price of these levels of development has been high grizzly bear mortality, even in Banff National Park, and especially in the female cohort, during the 1970s and 

into the 1980s (Benn In prep.). While we found that Banff National Park had the lowest percentage of its lands in the zone of human influence of any jurisdiction, all of 118 known grizzly bear mortalities, 1971-1996, and studied by Benn, occurred in this zone. This gives further support to the function of secure habitat in buffering grizzly bears from mortality (see Grizzly bear mortality, this report).

To facilitate use by bears, security areas should remain in place for some minimum period of time. This duration is based on the time required for a female to mature and replace herself (one generation). Mattson (1993) calculated this to be circa 11 years for a wary female grizzly bear in the Yellowstone system. To maintain a grizzly bear population, long term maintenance of secure habitat is necessary.

The results of the time series security area analysis (which included only Banff National Park and Kananaskis Country) clearly demonstrated the decreasing size over time of relatively undisturbed habitat units. This habitat fragmentation effect has occurred throughout Kananaskis Country. The decreasing size of security areas was paralleled by a significant decrease in total amount of security area available throughout Kananaskis Country.

We can surmise, but cannot demonstrate scientifically, that compromised habitat security and habitat fragmentation are having demographic effects by decreasing grizzly bear population size and, possibly, long-term population viability. Doak (1995) reached a similar conclusion regarding the linkage between habitat degradation and potential population depression in the Yellowstone ecosystem. We cannot scientifically demonstrate demographic and viability effects because baseline data from the past do not exist. However, existing regional mortality and translocation data, combined with our findings of low security and high habitat fragmentation within adult female home ranges, present converging evidence that suggest grizzly bear population depression across the region.

The concept of security areas also includes dimensions of habitat quality, shape, spacing, and connectivity between female home ranges. Mattson (1993) points out that linking security areas based on individual foraging bouts into a security area network is fundamental to the concept. We have not addressed these dimensions in this analysis although we recognize it is the next logical, and perhaps the most challenging, step. These identifiable characteristics are currently under development as we gain a better understanding of the needs of grizzly bears in the Canadian Rocky Mountains. 



\section{SUMMARY AND CONCLUSIONS}

\section{The grizzly bear population}

(see Introduction, Population overview and Grizzly bear mortality, pp. 1-15; and Maps 2 and 3 , pp. 7 and 15 )

The population and habitat status of grizzly bears in Kananaskis Country and the surrounding ecosystem can be viewed as an indicator of regional ecological integrity. This is because grizzly bears are a species with little resiliency. Because of large home ranges and movements, low population densities, low total population numbers, a very low reproductive rate and occasional direct conflict with people, grizzly bears are easy to remove or lose from any area. These biological characteristics have lead to grizzly bears being classified as a vulnerable species nationally, and as a species at risk (blue listed) in Alberta.

Historically grizzly bears were distributed throughout what is today Kananaskis Country. Now they are apparently significantly reduced in density in eastern portions of Kananaskis Country, and somewhat reduced in density in western portions.

Today there are few grizzly bears in Kananaskis Country. Although the science behind current grizzly bear population estimates for Kananaskis Country is not exact, population estimates range from 50 to 38 for Kananaskis Country and adjacent portions of the Bow Crow Forest of south-western Alberta. These low numbers, coupled with some of the grizzlies' other biological traits, mean that grizzly bear mortality management is fundamental to population persistence. This is especially true for adult female grizzly bears which are the reproductive engine of the population.

Our study of grizzly bear mortalities and removals (here after referred to as mortalities) in Kananaskis Country revealed that the grizzly bear hunting closure instituted in 1970 appears to have been successful at bringing mortality levels within scientifically accepted limits. Human-induced mortalities have not been eliminated, though they have been significantly reduced. We estimate a human-induced, known mortality rate for the period $1972-1997$ of $2.9 \%$ (32 known mortalities; $1.2 /$ year). Females contributed only $0.9 \%$ to this overall rate. Even if these estimates are off by $100 \%$, which is unlikely, the total human-caused mortality rate is still below $6.5 \%$, the scientifically accepted rate below which such mortality is not considered a cause of population decline. However, current mortality rates may continue to increase, even without more recreational use or development, as older adult females, who have had many years to adjust to changing land uses, are replaced by young females who have to develop home ranges without long term knowledge of resources or human influences on the landscape.

Also, the Kananaskis mortality rate must be considered in the regional context where grizzly bear hunting still occurs. Other mortality sources are in some places not as conservatively managed as in Kananaskis Country. Both in Kananaskis Country and regionally, human developments and activities both stress grizzly bears and increase mortality probabilities. Mortality probabilities through interaction with people will 

probably increase as Calgary and surround continue to grow and place more recreational and other resource demands on Kananaskis Country.

Human-induced grizzly bear mortality is still the primary management concern for grizzly bear persistence. Our study of mortalities showed that the majority $(53 \% ; 17 / 32)$ were related to ungulate hunting. Problem wildlife related grizzly bear mortalities are becoming increasingly important. During 1981-1997, 44\% (11/25), of all mortalities were of this type. Problem wildlife situations involving grizzly bears result from a juxtaposition of important grizzly bear resources, such as berries or early season grasses, with zones of human activities such as roadsides or golf courses. They also result from breakdowns in Kananaskis Country's generally excellent management of people's foods and garbage which may become dangerous attractants for grizzly bears. Most grizzly bears died in areas where human access was good. Ninety-six percent (24/25) of all mortalities where location could be determined were within $500 \mathrm{~m}$ of a road or $200 \mathrm{~m}$ of a trail.

While current mortality levels appear to be acceptable for population persistence, data regarding births and recruitment into the adult population, the other essential dimension of a viable population, suggest concern because of very low cub production. The only reported, scientifically vetted estimate of the average number of young produced by Kananaskis Country adult female grizzly bears per year is 0.46 (Wielgus and Bunnell 1994). This is one of the lowest reproductive rates reported in North America. Wielgus and Bunnell (1994) believe this low rate may be the complex consequence of high adult male mortality in the broader region, with this leading to a preponderance of young adult males that potentially and actually kill cubs, and because of this displace adult females from high quality habitats which they need to produce larger litters.

Currently we do not know whether the Kananaskis Country and regional population is increasing or decreasing. One of the major research objectives of the Eastern Slopes Grizzly Bear Research Project is to determine this. Unfortunately scientifically acceptable estimates of growth rate require 5-10 years of reproductive and mortality data. We will provide an estimate as soon as data are sufficient.

\section{Grizzly bear habitat, movements and security}

\section{$\underline{\text { Habitat and movement areas }}$}

Relatively low grizzly bear population number, density and reproduction relate fundamentally to habitat productivity, especially of energy rich foods such as berries and ungulates. Our major efforts regarding grizzly bear habitat classification and mapping showed a patchy distribution of highly suitable habitat and associated food resources. This is the biophysical reason for the large home range sizes we have found for grizzly bears in the region (300 sq. $\mathrm{km}$. for females, $1500 \mathrm{sq}$. km. for males). Grizzly bears must be able to move widely and safely throughout their home ranges to access seasonally available resources. This is why developments and human activities must be carefully managed if grizzly bears are to be maintained. This is particularly important along important movement areas which give certain grizzly bears access to different watersheds 

isolated by mountain ranges. Examples of these are given (see Wildlife movement areas of Kananaskis Country, p.17). Some particularly important ones, from north to south, appear to be: Skogan Pass, Goat Creek, the south end of Spray Lakes, Burstall Pass, Little Elbow/Evans Thomas Pass, North Kananaskis Pass, Elbow Pass, Elk Pass, Highwood Pass, Weary Creek Gap, Fording River Pass, and a series of drainages from south Kananaskis Country into the Oldman and Livingstone River Valleys.

Suitable habitat (habitat quality)

(see pp. 19-22, and Maps 5 and 6, pp. 23 and 24, for principal findings)

For analysis purposes we divided the grizzly bear foraging season into two ecologically defined periods. The first being before berries are ripe, and the second when berries are ripe and afterward. Generally, habitat suitability varies spatially and seasonally based on the occurrence of key plant and animal foods on the landscape.

During the pre-berry season concentrations of highly suitable habitat were found in the areas immediately south and north of Spray Lake, the Elk Pass area, the Smith-Dorrien River Valley, and on private lands between Bull Creek and the Highwood River east of Highway 541. During the pre-berry season, highly suitable habitat tends to cluster along most major river systems including the Kananaskis, Highwood and Bow River valleys. This was especially true for areas in the north-western Main Range portion of Kananaskis Country where there is a lot of rock and ice and only patches of grizzly bear habitat. Areas of high habitat suitability during the pre-berry season tended to be more extensive and evenly distributed in the Front Ranges. This was related to large amounts of south to west facing Aspen, Lodgepole Pine forests, low elevation grasslands, and riparian forests. This was consistent with grizzly bear telemetry research findings that show spring and early summer movements of especially male bears to front range habitats.

Patches of highly suitable habitat were more localized during the berry-and-after season. Notable areas of concentration of highly suitable berry-and-after season habitat included: the Odlum and Loomis Creek valleys and the southwest-facing slopes of the Highwood Range; the headwaters of Etherington Creek, Baril Creek, and the valley sides of Cummins and Lost Creek; the Smuts Valley off of the Smith-Dorrien Creek; the Cox Hill - Jumpingpound Creek area; the upper extent of Threepoint Creek, and the Moose Mountain Creek - Jumpingpound Mountain area. Highly suitable berry-and-after season habitats are generally limited in eastern portions of the Front Ranges in Kananaskis Country.

\section{Habitat effectiveness}

(see pp. 25-29, and Table 5, p. 25, for principal findings)

To estimate the extent to which peoples' developments and activities influenced grizzly bear use of habitat we applied two models developed in the United States and widely accepted as first approximations of human influence on habitat use, alienation and security. These were the habitat effectiveness model and security area analysis. 

Habitat effectiveness values estimate the percentage of habitat that is available after subtracting habitat alienated as a result of human influences. Units of analysis approximate the size and character of a female grizzly bear's home range and are called Bear Management Units (BMUs). For 13 BMUs in Kananaskis Country, habitat effectiveness values ranged from $49 \%$ to $82 \%$ and averaged $71 \%$. In Banff National Park prior work showed an average habitat effectiveness value of $83 \%$. The lowest habitat effectiveness values (below 70\%) in Kananaskis Country were found in BMUs in the western Main Ranges. Generally these were areas where roading and recreational development and activities were greatest. BMUs associated with the inter-mountain ranges further east generally had few primary or secondary roads and had highly effective habitat.

Research in the United States suggests that habitat effectiveness values of less than 70$80 \%$ could exceed the grizzlies' threshold of acceptance of disturbance and lead to abandonment of the area for other than occasional foraging. Low habitat effectiveness values also increase mortality probabilities for grizzly bears. Five of thirteen BMUs in Kananaskis Country had habitat effectiveness values of less than $70 \%$ suggesting considerable stress on grizzly bears using these areas.

\section{Habitat and security}

(see pp. 29-42, and Maps 8-11, pp. 33-39, for principal findings)

The other technique we used to understand the relationship between people's developments and activities and grizzly bear habitat was security area analysis. Through this technique, which we applied to female grizzly bear home ranges found in Kananaskis Country and the greater region (Central Canadian Rockies Ecosystem), we identified the percentage of each of 20 adult female grizzly bears' home ranges that was free enough from development to offer a low probability of disturbance during daily foraging activities. This "secure" habitat is fundamental to fostering behavioural avoidance of people. It helps to discourage habituation and food-conditioning which may lead to grizzly bears being removed as problem wildlife.

Security area analysis showed that of four jurisdictions studied, Kananaskis Country had the largest percentage (38\%) of its landscape classified as being within the zone of high human influence. An additional $24 \%$ of Kananaskis Country was classified as unsuitable habitat because it was non-productive rock or ice. This left only $38 \%$ of Kananaskis Country's land in secure status. Throughout the region of our analysis which included Banff, Yoho and Kootenay National Parks, and adjacent Alberta and British Columbia crown lands, the three most affected female home ranges were all exclusively within Kananaskis Country. All female home ranges in Kananaskis Country fell below regional average habitat security values of $44 \%$. This helps to explain the growing problem with habituated grizzly bears and with grizzly bear mortalities classified as problem wildlife. Grizzly bears are finding fewer and fewer opportunities to meet their daily or yearly needs without association with people. In the United States target values for habitat security are tentative, but range from $57 \%-67 \%$, well beyond the Kananaskis Country value of $38 \%$. Projection of proposed development and use trends into the future showed grizzly bear 

habitat being fractionated into ever smaller non-disturbed units thus further stressing individuals and the population.

Assessment of both habitat effectiveness and security area analysis suggest significant to severe stress on grizzly bears in Kananaskis Country. Our results suggest this contributes significantly to mortalities. It may also contribute to low cub production.

\section{RECOMMENDATIONS}

\section{Regarding grizzly bear mortality and reproduction:}

Because effective management of human-caused grizzly bear mortality, especially for females, is fundamental to population persistence there is a need for explicit, sex specific, mortality targets and regular monitoring and analysis of mortalities in this regard. There is also a need for management actions that will continue to decrease mortality probabilities. Such actions should include:

a. To help decrease problem wildlife removal of grizzly bears, continue the emphasis on decreasing the availability of human-related attractants such as peoples' food and garbage. This could be achieved by enacting regulations that would require all campers (hikers, equestrian, and hunters) to store food, garbage, and horse feed in bear proof metal or seamless PVC containers, or to effectively elevate such attractants between two trees.

b. To address the increased mortality risk for grizzly bears that have little habitat security and must live near people in high use areas (such as the Ribbon Creek-EvansThomas Creek area) and hence become habituated (used to being near people), better management of people with guns is needed. This could be achieved by: 1) implementing roadside wildlife sanctuaries, such as already exist in the Highwood Pass area, along all driveable roads in Kananaskis Country, 2) providing funding to continue and expand comprehensive and intensive management of grizzly bears including aversive conditioning of roadside grizzly bears and bears entering areas of concentrated human activities.

c. To address the increased mortality risk to grizzly bears associated with corridors of human access (95\% of all human-caused grizzly bear mortality occurred nearby roads or trails) careful review and management of human access is needed.

d. To further protect adult female grizzly bears and their families, continue to implement closures when grizzly bear family groups are using important feeding sites that have transient human use, or when a female displays defensive or protective aggressive behaviour.

e. To further decrease chances of grizzly bear mortality and human injury, continue and expand efforts at informing the public about bear activity in Kananaskis Country. Also, continue the educational programs suggesting how to behave in grizzly bear country. Some programs should be developed specifically for groups most likely to 

cause avoidable grizzly bear mortality (e.g., ungulate hunters, backcountry campsite users, mountain bikers). A unique opportunity to inform ungulate hunters regarding grizzly bear behaviour and ecology exists for those chosen in limited entry draws which take place each year for Kananaskis Country.

f. To scientifically determine whether the Kananaskis Country and regional grizzly bear population is increasing or decreasing, continue to financially support at least this aspect of the Eastern Slopes Grizzly Bear Project. This will require long term data not only on mortality but also on reproduction.

\section{Regarding grizzly bear habitat, security areas, and movements:}

Suitable habitat has a restricted and patchy distribution, and both habitat effectiveness and habitat security were found to be significantly compromised, thus increasing mortality probabilities. For these reasons, policy changes and enabling planning and management actions are needed to restore and maintain productive habitat less compromised by people's developments and activities. We recommend the following:

a. Particular attention should be given to preventing further loss of habitat effectiveness and security especially in high quality habitats where highly suitable seasonal grizzly bear habitat exists. Such areas have been tentatively identified in our research and in previous research by McCrory and Herrero (1983a,b) and by McCrory et al. (1982). Examples of such sites would be all valley bottom locations in the main ranges, but especially the southern end of Spray Lake and the Evans Thomas Creek fan. Each development proposal should be carefully weighed in terms habitat suitability, effectiveness loss and loss of habitat security.

b. Human impacts on movement areas (see p. 17) that grizzly bears use should be managed at levels that will encourage movement by grizzly bears, taking into account the results of our habitat security analysis.

c. Steps should be considered to increase habitat suitability (quality) for grizzly bears, especially for energy rich foods such as berries and ungulates. The use of fire, creation of selective clearings, and even certain designs of timber harvesting can potentially enhance grizzly bear habitat. Fire suppression policies have probably significantly decreased habitat productivity for ungulates and grizzly bears. Habitat enhancement measures must begin by creating suitable habitat. In addition, human access to this habitat must be managed to encourage grizzly bear use, as habitat effectiveness and security are also important.

\section{Regarding scientific research on grizzly bears and the relationship of such knowledge to regional land use policy formation, planning, and management:}

Because certain aspects of grizzly bear biology make their populations susceptible to decline, and because human activities and developments continue to expand in Kananaskis Country and impact grizzly bear population and habitat, there will be a continuing need to financially support research that provides defensible, scientific 

information on grizzly bear population and habitat status. Since some of this knowledge is best portrayed in models such as the habitat effectiveness model and Security Area Analysis, model assumptions such as thresholds related to human use levels and the zone of influence of human use need further research to gain greater precision. Also, research linking habitat suitability (quality), effectiveness, and security with population viability should be supported. This could contribute significantly to more science-based population and habitat management. This evolving knowledge needs to be formally and regularly input into regional policy and planning decisions, and needs managers who have the necessary finances and person power to implement those decisions. 



\section{LITERATURE CITED}

Bader, M. 1995. A dubious plan for grizzly bear recovery in the Northern Rockies. Wild Forest Review. Oct/Nov. 29-31.

Banff-Bow Valley Study. 1996. Banff-Bow Valley: At the crossroads. Technical report of the Banff-Bow Valley Task Force. Prepared for Minister of Canadian Heritage, Ottawa, Ontario 427pp.

Benn, B. In prep. Grizzly bear mortality in the Central Rockies Ecosystem. Master's Degree Project. Faculty of Environmental Design. University of Calgary.

Brown, D.E. 1985. The Grizzly Bear in the Southwest. University of Oklahoma Press. Norman. 274 pp.

Carr, H.D. 1989. Distribution, numbers, and mortality of grizzly bears in and around Kananaskis Country, Alberta. Fish and Wildl. Div. Wildl. Manage. Branch Wildl. Res. Series 3. 49 pp.

Caughley, G. 1994. Directions in conservation biology. Journal of Animal Ecology 63:215-244.

Collister, D.M. and J.L. Kansas. 1996. Wildlife habitat assessment - Moose Mountain Environmental Inventory. Prepared by GAIA Consultants Inc. for Husky Oil. 68 pp.

Cottingham, D. and R. Langshaw. 1981. Grizzly Bear and Man in Canada's Mountain Parks. Summerthought Ltd. Banff, Alberta. 60 pp.

Craighead, J.J. and J.A. Mitchell. 1982. Grizzly bear. Pages 515-556 IN: Chapman, J.A. and Feldhamer, G.A. eds. Wild animals of North America: biology, management and economics. John Hopkins Univ. Press, Baltimore, MD.

Doak, D.F. 1995. Source-sink models and the problem of habitat degradation: General models and applications to the Yellowstone grizzly. Conservation Biology 9:1370-1379.

ERCB (Energy Resource Conservation Board). 1994. Decision report D.94-8, Application for an exploratory well, Amoco Canada Petroleum Company Ltd., Whaleback Ridge Area, ERCB, Edmonton.

Gibeau, Michael L. and Stephen Herrero. In press. Managing for grizzly bear security areas in Banff National Park and the Central Canadian Rocky Mountains. Int. Conf. Bear Res. and Manage. 11:000-000.

Gibeau, M.L. 1998. Grizzly bear habitat effectiveness model for Banff, Yoho and Kootenay National Parks, Canada. International Conference on Bear Research and Management 10:In press. 

and Stephen Herrero. 1997. Eastern slopes grizzly bear project: 1996 Progress report. Univ. of Calgary, AB.

and Stephen Herrero. 1996. Eastern slopes grizzly bear project: 1995 Progress report. Univ. of Calgary, AB. 46 pp.

, Stephen Herrero, John L. Kansas and Bryon Benn. 1996. Grizzly Bear Population and Habitat Status in Banff National Park. A Report to the Banff Bow Valley Task Force. University of Calgary. $62 \mathrm{pp}$.

1995. Grizzly bear habitat effectiveness model for Banff, Yoho and Kootenay National Parks, Canada. Int. Conf. Bear Res. and Manage. 10: In press.

Green, G.I., D.J. Mattson and J.M. Peek. 1997. Spring feeding on ungulate carcasses by grizzly bears in Yellowstone National Park. Journal of Wildlife Management 61:1040-1055

Gunson, J.R. 1996. Analysis of limited-entry grizzly bear hunts in Alberta during 19881996. Occasional Paper \#17. Wildl. Manage. Div., Alberta Env. Protection, Natural Resources Service. Edmonton, AB. 18 pp.

1995. Analysis of grizzly bear mortalities in Alberta during 1972-1994. Occasional Paper \#16. Wildl. Manage. Div., Alberta Env. Protection, Natural Resources Service. Edmonton, AB. 101 pp.

Hamer, D. and S. Herrero. 1983. Ecological studies of the grizzly bear in Banff National Park. Final report. Rep. prep. for Parks Canada by Univ. of Calgary, AB. Submitted to Western Regional Office of Parks Canada, Calgary. 303 pp.

Harris, R.B. 1986. "Modelling sustainable harvest rates for grizzly bears." In Programmatic Environmental Impact Statement - The Grizzly Bear in Northwestern Montana. A. Dood, R. Brannon, and R. Mace (Eds.). Montana Dept. Fish, Wildlife and Parks. Helena, MT. 268-279.

Herrero, S. and J. Herrero. 1996. Cheviot Mine Project: Specific and cumulative environmental effects analysis for mammalian carnivores. Prep. by BIO Environmental Research and PLanning Associates Ltd. for Cardinal River Coals Ltd. 122pp.

D. Poll, M. Gibeau, J. Kansas, and B. Worbets. 1996. The Eastern Slopes Grizzly Bear Project: Origins, organization, and direction. Canadian Council on Ecological Area (CCEA) Annual Confernce. Calgary, Alberta. interagency management. Int. Conf. Bear. Res. and Manage. 9: 7-21. 

1992. The significance of Wind Valley for mammalian carnivores. Prepared for the Canadian Parks and Wilderness Society, and submitted to the Natural Resources Conservation Board's hearing on the proposed Three Sisters development in the Bow corridor. 23 pp.

1994. The grizzly bear and the east slopes of Kananaskis Country, Alberta, Canada. In: Komex International (Eds.), Proceedings Eastern Slopes Regional Wildlife Workshop, March 30 and 31, 1994, Calgary, Alberta, pp. 76-86.

, Wayne McCory, and Brian Pelchat. 1986. Using grizzly bear habitat evaluations to locate trails and campsites in Kananaskis Provincial Park. Int. Conf. Bear Res. and Manage. 6:187-193.

1985. Bear attacks: Their causes and avoidance. Lyons and Burford, New York, NY. 287 pp.

1978. A comparison of some features of the evolution, ecology and behaviour of black and grizzly/brown bears. Carnivore 1(1): 7-17.

Hovey, F.W. and B.N. McLellan. 1996. Estimating population growth of grizzly bears from the Flathead River drainage using computer simulations of reproduction and survival rates. Can. J. Zool. 74:1409-1416.

Interagency Grizzly Bear Committee. 1994. Grizzly bear / motorized access management. Interagency Grizzly Bear Committee Task Force Report. 7 pp.

Kansas, J.L. In prep. Investigating the habitat mapping and evaluation basis of grizzly bear cumulative effects assessment.

and S. Herrero. 1994. Eastern Slopes Grizzly Bear Project: Habitat component Year 2. Progress Report.

and R.N. Riddell. 1995. Grizzly bear habitat model for the four contiguous mountain national parks: Second Iteration. Report for Canadian Parks Service, Calgary, Alberta 109 pp.

Kie, J.G., J.A. Baldwin, and C.J. Evans. 1996. Calhome: a program for estimating animal home ranges. Wildlife Society Bulletin 24:332-344.

Knight, R.R., B.M. Blanchard, and L.E. Eberhardt. 1988. Mortality patterns and population sinks for Yellowstone grizzly bears, 1973-85. Wildl. Soc. Bull. 16:121-125.

Komex International. 1995. Atlas of the Central Rockies Ecosystem. Report to the Central Rockies Ecosystem Interagency Liaison Group. Calgary, Alberta 49 pp. 

LeFranc, M.N., M.B. Moss, K.A. Patnode, and W.C. Sugg editors. 1987. Grizzly bear compendium. Interagency Grizzly Bear Committee and National Wildlife Federation, Washington, D.C.

Mace, R.D., and J.S. Waller. 1997. Final report: grizzly bear ecology in the Swan Mountains. Montana Fish, Wildlife, and Parks Department, Helena, Montana 191 pp.

, J.S. Waller, T.L. Manley, L. Jack Lyon and H. Zuuring. 1996. Relationships among grizzly bears, roads, and habitat in the Swan Mountains, Montana. Journal of Applied Ecology (In press).

, and T.L. Manley. 1993. South Fork Flathead River grizzly bear project: progress report for 1992. Mont. Dep. Fish, Wildl. and Parks, Helena. 34 pp.

Mattson, D.J., S. Herrero, R.G. Wright, and C.M. Pease. 1996a. Science and management of rocky mountain grizzly bears. Conservation Biology 10(4):1013-1025.

, S. Herrero, R.G. Wright, and C.M. Pease. 1996b. "Designing and managing protected areas for grizzly bears: how much is enough?" In National Parks and Protected Areas: Their role in Environmental Protection. R.G. Wright (ed.). Blackwell Science. Cambridge, Mass. 480 pp.

1993. Background and proposed standards for managing grizzly bear habitat security in the Yellowstone ecosystem. Co-operative Park Studies Unit report. University of Idaho, Moscow, Idaho $17 \mathrm{pp}$.

, B.M. Blanchard, and R.R. Knight. 1992. Yellowstone grizzly bear mortality, human habituation, and whitebark pine seed crops. Journal Wildlife Management 56:432-442.

1990. Human impacts on bear habitat use. International Conference on Bear Research and Management 8:33-56.

, R.R. Knight and B.M. Blanchard. 1987. The effects of developments and primary roads on grizzly bear habitat use in Yellowstone National Park, Wyoming. Int. Conf. Bear Res. and Manage. 7:259-273.

McCrory, W. and S. Herrero. 1983a. The capability and use of grizzly bear habitats in the Kananaskis and Spray Lakes valleys and areas from Canmore to Mt. Allan, 1982. Rep. for Alta. Fish and Wildl. Div. Calgary. BIOS Env. Res. and Planning Assoc. Ltd. 249 pp. and S. Herrero. 1983b. The capability and use of grizzly bear habitats in the headwaters of the Little Elbow, Elbow, Sheep, and Highwood valleys, 1982. Rep. for Alta. Fish and Wildl. Div. Calgary. BIOS Env. Res. and Planning Assoc. Ltd. 249 pp. 

and S. Herrero. 1982. A review of the historical status of the grizzly bear in Kananaskis Country, Alberta. BIOS Env. Res. and Planning Assoc. Ltd. Prepared for Alberta Fish and Wildlife Division. Calgary, Alberta. 123 pp.

S. Herrero and T. Toth. 1982. Grizzly bear habitat potential and feeding areas in the Kananaskis and Spray Lakes valleys. Rep. for Alta. Fish and Wildl. Div. Calgary. BIOS Env. Res. and Planning Assoc. Ltd. 372 pp.

and S. Herrero. 1981. An evaluation of grizzly bear autumn feeding sign and habitat in the upper Highwood River valley, Alberta. Rep. for Alta. Fish and Wildl. Div. Calgary. 178 pp.

McGregor, C.A. 1984. Ecological Land Classification and Evaluation. Kananaskis Country Volume 1. Natural Resource Summary. Resource Evaluation Branch, Alberta Energy and Natural Resources. Edmonton. 111 pp.

Nagy, J.A. and J.R. Gunson. 1988. Tavbular appendices: Management plan for grizzly bears in Alberta. Alberta Forestry, Lands, and Wildlife, Fish and Wildl. Div., Edmonton.

Nagy, J.A. and J.R. Gunson. 1990. Management plan for grizzly bears in Alberta. Alberta Forestry, Lands, and Wildlife, Wildl. Manage. Planning Series Number 2. 164 pp.

Newmark, W.D. 1985. Legal and biotic boundaries of Western North American national parks: A problem of congruence. Biol. Consv. 33: 197-208.

Noble, L.B. 1972. Man and grizzly bear in Banff National Park, Alberta. M.A. Thesis. University of Calgary, AB. 119 pp.

Noss, R.F., H.B. Quigley, M.G. Hornocker, T. Merrill, and P.C. Paquet. 1996.

Conservation biology and carnivore conservation in the Rocky Mountains. Cons. Bio. 10:949-963.

1987. From plant communities to landscapes in conservative inventories: A look at the Nature Conservancy (U.S.A.). Biol. Conserv. 41: 11-37.

NRCB (Natural Resources Conservation Board). 1993a. Decision report. Application to construct a recreational tourist resort project in the town of Canmore, Alberta. Application 9103 - Three Sisters Inc. NRCB, Edmonton.

1993b. Decision report. Vacation Alberta Corporation application to construct recreational and tourist facilities in the West Castle Valley, near Pincher Creek, Alberta. NRCB, Edmonton.

Parks Canada. 1997. Banff National Park Management Plan. Ministry of Canadian Heritage, Ottawa, Ontario 85pp. 

Puchlerz, T. and C. Servheen. 1994. Grizzly bear/motorized access management. Task force report to Interagency Grizzly Bear Committee. USDI Fish and Wildlife Service, Missoula, Montana 8 pp.

Raine, R.M. and R.N. Riddell. 1991. Grizzly bear research in Yoho and Kootenay National Parks. Canadian Parks Service Report, Calgary, Alberta.

Reinhart, D.P. and D.J. Mattson. 1990. Bear use of cutthroat trout spawning streams in Yellowstone National Park. International Conference on Bear Research and Management 8:343-350.

Russell, R.H., J.W. Nolan, N.G. Woody, and G.H. Anderson. 1979. A study of the grizzly bear in Jasper National Park 1975 to 1978. Canadian Wildlife Service, Edmonton. 102 pp. Plus 10 appendices.

Stelfox, H.A. 1991. Assessing land/wildlife relationships via the ecological land evaluation. Pages 29-46 IN: Stelfox, H.A., Ironside, G.R. and Kansas, J.L. eds. Guidelines for the integration of wildlife and habitat evaluations with ecological land survey. Wildl. Working Group of Can. Comm. on Ecol. Land Class. Publ. by Wildlife Habitat Canada and Can. Wildl. Serv. Ottawa. 107 pp.

Stegner, Wallace. 1962. Wolf Willow. Penguin Books, New York, NY. 306 pp.

Stelmock, J.J. 1981. Seasonal activities and habitat use patterns of brown bears in Denali National Park-1980. M. Sc. thesis, Univ. of Alaska. 118 pp.

Storer, T.I. and L.P. Tevis Jr. 1955. California Grizzly. University of California Press. Berkeley. $335 \mathrm{pp}$.

USDA Forest Service. 1990. CEM - A model for assessing effects on grizzly bears. U.S. Dep. Agric. For. Serv., Missoula, Montana. 24 pp.

USFWS (United States Fish and Wildlife Service). 1993. Grizzly bear recovery plan. United States Fish and Wildlife Service, Missoula, Montana. 24 pp.

Weaver, J.L., P.C. Paquet, and L.F. Ruggiero. 1996. Resilience and conservation of large carnivores in the Rocky Mountains. Cons. Bio. 10: 964-976.

Weaver, J.L., R.E.F. Escano, and D.S. Winn. 1987. A framework for assessing cumulative effects on grizzly bears. North American Wildlife and Natural Resources Conference 52:364-376.

, R. Escano, D. Mattson, T. Puchlerz, and D. Despain. 1986. A cumulative effects model for grizzly bear management in the Yellowstone Ecosystem. Pages 234-246 IN: Contreras, G.P. and Evans, K.E. eds. Proceedings-Grizzly bear habitat symposium. Intermountain Res. Stn. Gen. Tech. Rep. INT-207. 252 pp. 

Wielgus, R.B. and F.L. Bunnell. 1994. Dynamics of a small, hunted brown bear (Ursus arctos) population in southwestern Alberta, Canada. Biol. Consv. 67: 161-166.

Wiken, E.B. 1986. Terrestrial ecozones of Canada. Ecol. Land Classif. Series, No. 19. Lands Dir., Environment Canada, Ottawa. 25pp.

Worton, B.J. 1989. Kernal methods for estimating the utilization distribution in homerange studies. Ecology 70:164-168

Young, F.M. and C. Beyers. 1980. Man Meets Grizzly. Houghton-Mifflin Co. Boston. $298 \mathrm{pp}$.

\section{PERSONAL COMMUNICATIONS}

Bryant, Richard. Alberta Fish and Wildlife Officer, Elbow District

Donelon, S. Protected Areas Coordinator, Natural Resources Service, Bow Region

Gibeau, M. Principal Researcher, Eastern Slopes Grizzly Bear Project.

Horning, Rocky. Alberta Fish and Wildlife Officer, Peter Lougheed Provincial Park

Knight, R. Research biologist, United States Biological Survey. Moscow, Idaho.

Paquet, P. Research biologist. John-Paul Associates. Meacham, Saskatchewan. 



\section{APPENDIX A: METHODOLOGIES}

\section{Grizzly bear mortality}

\section{Methods}

\section{The database}

Alberta Environmental Protection, Fish and Wildlife Division (AFWD) supplied grizzly bear mortality data from 1972, when compulsory registration for successful hunters was implemented, to 1996 (Gunson 1995 and addenda), translocation files from 1974 to 1996, hunter registration certificates, and district occurrence reports. Four additional deaths, 1 reported incidentally by a Fish and Wildlife Officer during an interview regarding another mortality, 1 probable natural mortality identified by ESGBP researchers, and 2 known human-caused mortalities from 1997 are also included in the database.

Mortalities include dead bears, and bears translocated so far that they represent additional losses to the population of the removal area. Information from the mortality and translocation files were integrated with respect to the following attributes:

- Location (Easting and Northing in civilian UTM coordinates)

- Date of occurrence (year and month)

- Sex (male, female, unknown)

- $\quad$ Age (dependent $=$ cub of year, yearling, and 2 year old; sub-adult = 3-5 years of age; adult $=6$ years of age and older, unknown)

- Mortality type ( $\mathrm{LH}=$ legal harvest, $\mathrm{PW}=$ problem wildlife, $\mathrm{IL}=$ illegal, $\mathrm{SD}=$ selfdefence, $\mathrm{TI}=$ Treaty Indian, $\mathrm{Re}=$ research, $\mathrm{N}=$ natural, $\mathrm{U}=$ unknown)

- Accuracy of the location (accurate, reasonable, estimate, unknown)

- Notes (nearby geographic or cultural feature, access information, distance from access route or facility, anecdotes regarding the history of the bear and circumstances of its death)

\section{Mortality summaries and rates}

We summarized human-caused grizzly bear mortality for the Kananaskis Country study area by annual number of mortalities, specific mortality type (cause of death), and by sex, age, and cohort.

We generated a population estimate for the Kananaskis Country study area by summing the population estimates for each Wildlife Management Unit (from Nagy and Gunson 1988). Bearing in mind that the growth rate in this population may have changed over time, for the purposes of comparison, we assume a constant population size.

We calculated the total known mortality rate and sex-specific mortality rates from 1972 97, and by analysis periods (1972-80 and 1981-97) for the study area, using the following equation: 

- mortality rate $=$ number of mortalities $/$ time period in years $/$ population estimate

\section{Spatial analyses}

Access data for the Kananaskis and adjacent land south of the Bow River, was supplied as 1:50,000 scale Alberta digital mapsheet files, by the Alberta Forest Service and Protected Areas Management, Kananaskis Country. Mortality locations (Gunson 1995 and addenda) were presented as legal land descriptions (LLD), usually only to the township and range and supplemented with the name of a nearby drainage or topographic or cultural feature. Occasionally the registration certificate or occurrence report for a particular incident gave a more accurate LLD to the section or quarter section. Interviews were conducted to acquire more details of each mortality (see below).

The access and mortality data were entered into a geographic information system (GIS), MapInfo 4.0 (MapInfo Corporation, Troy, New York) and road and trail buffers created. Based in part on research, and partly on standards of the Interagency Grizzly Bear committee (1994), we set zones of influence (ZOI) around roads at $500 \mathrm{~m}$ and trails at 200 $\mathrm{m}$. The road layer includes all roads open to the public and derivable by $2 \mathrm{wd}$ vehicle. The trail layer includes roads not open to the motorized vehicles, seismic lines, utility corridors, and any other linear access features accessible by hiking, biking, horseback, or all-terrain vehicle, but assumed not passable by $2 \mathrm{wd}$ vehicle. For ZOI area calculations, road and trail buffers were combined into a single coverage. The area of overlap was only calculated once. Mortality locations were overlain on access maps and the percentage of locations within the buffers was calculated. Locations in the area of overlapping buffers were analysed as occurring within road buffers.

\section{Interviews}

Mortality locations in the Alberta mortality database (Gunson 1995) were not accurate enough to spatially analyze the mortalities with respect to human access. Interviews were conducted with Fish and Wildlife officers, biologists, and park rangers, to determine as accurately as possible where the bears died, and to obtain additional information regarding each mortality, such as how far the kill site was off the access road or trail. This question was particularly important in ascertaining the accuracy of the location. As mortalities go back to 1972, some individuals were unable to come up with exact locations, but as long as they were able to remember the approximate location along an identified feature (river, stream, trail, etc.) and noted with confidence, the distance from the access route, the location was deemed "accurate". If a kill site was not described with confidence by the interviewee, but the description places it within some stated distance from a known road, trail, drainage or development, the location was classed as "reasonable". As they described these details, the information was recorded while following the route descriptions on a 1:50,000 NTS topographic map. All other mortalities were afforded a location if possible, based on available information and were classed as "estimate". These mortalities were not used in the spatial analyses. 



\section{Elevational analyses}

We determined the elevation for 32 grizzly bear mortality locations and plotted the frequency of mortalities by elevation for the study area. We compared these elevations with a series of elevations taken at arbitrary points along a sample of river valleys throughout the study area.

\section{Temporal analyses}

We stratified mortality data temporally to account for changing patterns of human use and evolving management concerns and actions, such as improved garbage management and road closures. Mortalities were analysed for the following time periods:

- 1972-80 - pre-road closures and no bear proof garbage facilities.

- 1981-96 - post-road closures and improved garbage management (bear-proof transfer system).

We compared hunting-related mortalities (SD, IL, TI, LH) with PW mortalities during the periods $1972-80$ and 1981-97 to identify changing patterns in causes of death and management strategies.

\section{Habitat assessment}

\section{$\underline{\text { Methods }}$}

\section{Delineate Bear Management Units}

Kananaskis Country was divided into Bear Management Units (BMU) each of which approximate the size and resource availability of a female annual home range. BMUs were delineated on the basis of topographic/watershed features, human facilities, and current knowledge of grizzly bear distribution and use. This division of the landscape was done to: 1) assess existing and proposed activities without having effects diluted by a large area; 2) correlate grizzly bear use and habitat ecology; 3 ) identify contiguous complexes of habitat which meet the year long needs of grizzly bears; and, 4) prioritize areas where management needs require closer scrutiny (USDA For. Serv. 1990).

\section{Habitat classification and mapping}

Vegetation and ecological conditions in Kananaskis Country were mapped at varying levels of detail depending on the intended end use. Bear Management Unit (BMU) boundaries were overlain onto an existing 1:100,000 scale Ecological Land Classification (ELC) by McGregor (1984; Map A-1) to characterize each BMU according to the occurrence and relative land areas of mapped "ecosections". Ecosections are recurring 

Grizzly Bear Status in K-Country * ESGBP

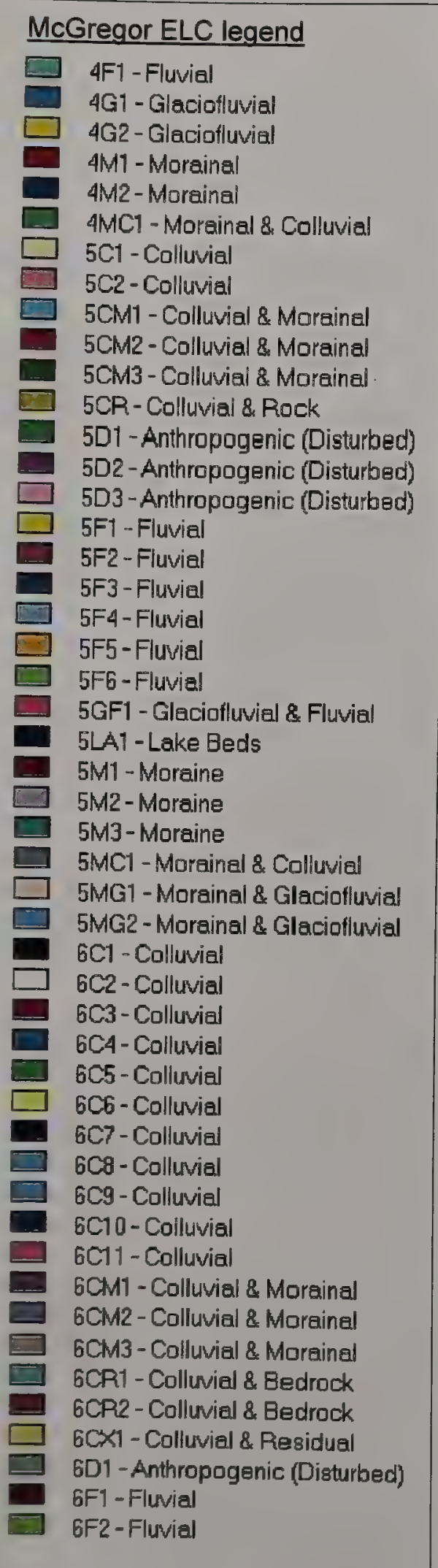

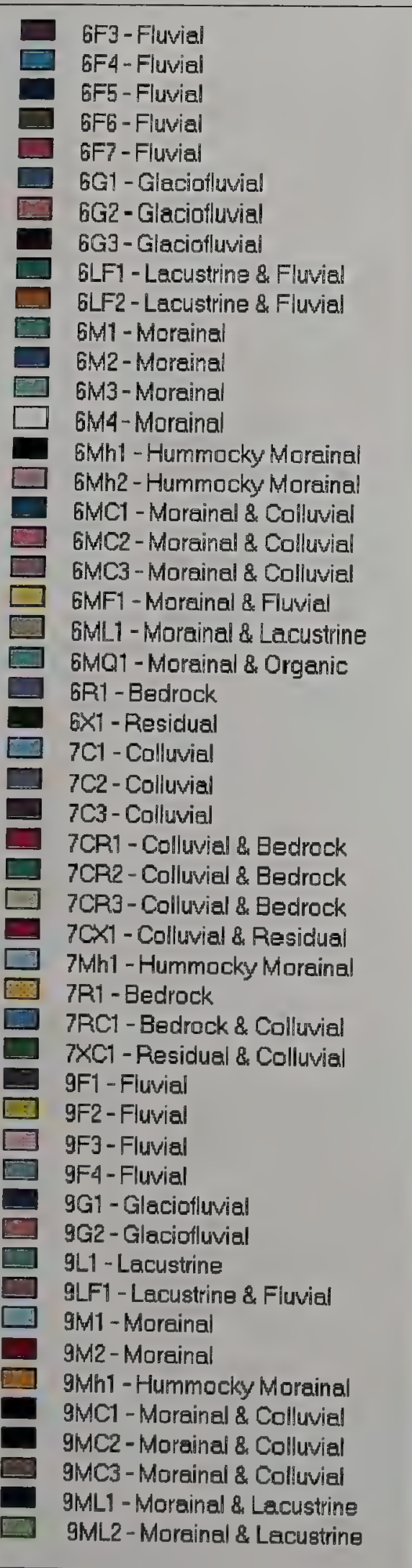

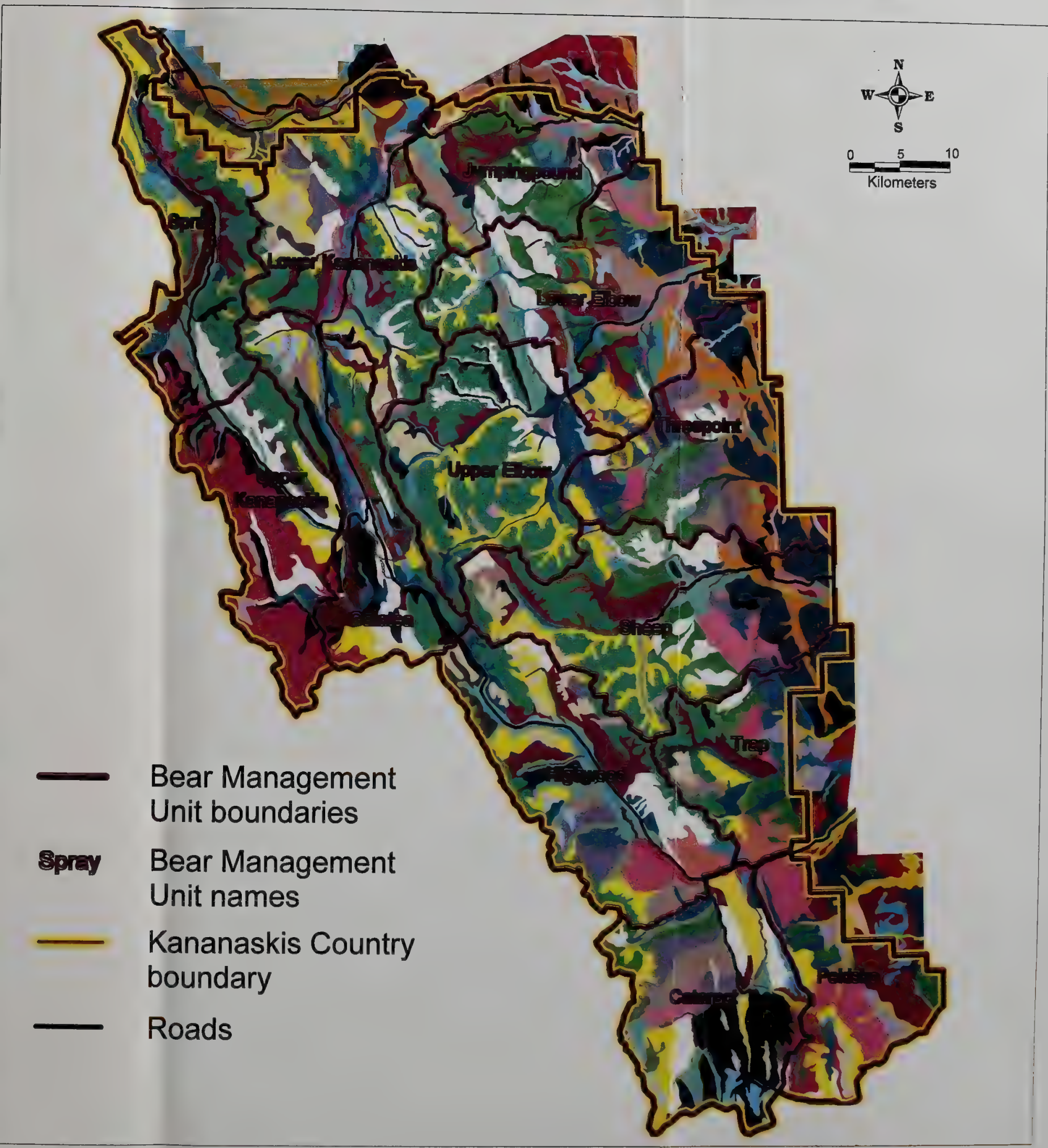

Map A-1. 1:100,000 scale ecosection mapping for Kananaskis Country (McGregor 1984). 
assemblages of terrain, soils, vegetation, water bodies and fauna and are usually mapped at scales of from 1:50,000 to 1:250,000 (Wiken 1986), and are used primarily for subregional planning purposes. Ecosections are rarely used for grizzly bear habitat suitability assessment because of the coarse mapping scale.

Finer 1:20,000 scale mapping was conducted in order to assess seasonal habitat suitability for grizzly bears. Land areas with recurring combinations of vegetation/land cover, aspect, slope angle and elevation (approximating Natural/Ecological Regions) were classified and mapped. Digital Alberta Vegetation Inventory (AVI) mapping was used as the basis for developing a map with 40 classes of vegetation/land cover. This was done through the grouping of AVI map polygons with similar combinations of forest cover or human use. An elevation map with 5 classes of elevation ranging from $<1375 \mathrm{~m}$ to $>2200 \mathrm{~m}$ asl. was developed from a 1:20,000 digital elevation model (DEM). Each class of elevation was based on the upper and lower limits of Natural Sub-regions occurring in the study area. Separate maps of aspect (3 classes) and slope angle (4 classes) were also developed from the DEM. An overlay of the vegetation/land cover, elevation, aspect and slope maps was conducted in Idrisi ${ }^{\circledR}$ (Clark Univ., Worcester, MA ) GIS to create a unique conditions map which delineated 535 different combinations of the classes originating from the four contributing maps. This "Level 5" habitat map represents the most detailed mapping product available for the Kananaskis Region. A typical Level 5 map unit might include the following diagnostic attribute data: Lodgepole Pine forest in the Lower Subalpine Natural Subregion (1600m to $1900 \mathrm{~m}$ asl) on south to west facing slopes of from $16 \%$ to $30 \%$ slope angle.

Level 5 map units were then grouped into 122 classes of habitat based on similarities in elevation, aspect and slope angle. This was done to facilitate habitat analysis. This "I_evel 4" habitat map is used as the basis for food-habits based grizzly bear habitat modelling.

Three additional levels of habitat mapping were developed based on further groupings of higher level mapping. Level 3 mapping comprises 40 classes of vegetation and land cover based on the grouping of AVI map polygons. Topographic (DEM) data was not used for this level of mapping. Level 2 and 1 mapping resulted in 15 and 6 generalized classes of vegetation/land cover, respectively.

\section{Habitat suitability assessment}

The Level 4 habitat mapping was used as a basis for evaluating seasonal grizzly bear habitat suitability and supply. This was completed as follows:

- Grizzly bear habitat plots were completed throughout Kananaskis Country from 1994 to 1998 as per the methodology outlined in Kansas and Herrero (1994). These detailed "Level 1" sampling plots collected detailed information on the percent cover of bear foods, hiding cover, and ant production.

- Each Level 1 field sampling plot was assigned to one of the 122 Level 4 habitat map units based on the vegetation cover type, slope, aspect, elevation, moisture regime and/or human use type recorded at the plot. 

- The mean percent cover of key grizzly bear foods was calculated for the sampling plots assigned to each Level 4 habitat map unit.

- A rating for ant production between 0.0 and 1.0 was calculated for the plots assigned to each Level 4 habitat map unit. This was based on the percent cover of woody and rock substrate and the frequency of occurrence of ants found under said substrate.

- Winter habitat suitability ratings between 0.0 and 1.0 were calculated for ungulates per Level 4 habitat map unit using algorithms developed by Collister and Kansas (1996) for moose and elk, and through consensus among 3 large mammal specialists for mule deer.

- An overall ungulate biomass rating for each Level 4 habitat map unit was calculated using relative individual biomass and winter habitat ratings. This value was calculated to reflect the potential availability of ungulate carrion to grizzly bears during the spring period.

- The habitat suitability value (0.0 to 1.0$)$ of Level 4 map units for the "pre-berry" (den emergence to July 15) and "berry-and-after" (July 15 to den entry) seasons was calculated by applying mathematical formulas developed by Herrero and Herrero (1996). These formulas reflected then relative importance of plant foods, ants and ungulates for each season as determined from grizzly bear scat collection spanning 4 years in the Cascade Valley of Banff National Park (Hamer and Herrero 1983).

- Habitat suitability values were normalized, multiplied by ten and rounded to the nearest whole number resulting in a number between 1 and 10 for each Level 4 habitat map unit and season.

- Habitat suitability values were then transferred to MapInfo® (MapInfo Corp., Troy, NY) GIS for mapping and display purposes.

\section{Assess potential habitat suitability of BMUs}

Habitat suitability values of between 1 and 10 for Level 4 habitat map units were calculated for two seasons using the methods outlined in the previous section. The habitat suitability values for the berry-and-after season were input into the GIS. The 10class rating scheme was converted to 5 habitat classes (Very High, High, Moderate, Low, Non) for ease of map interpretation. Colour maps of potential habitat values of 5 classes were created, and reflected the inherent habitat suitability of the BMU without taking into account existing human disturbance.

\section{Habitat effectiveness assessment}

Habitat effectiveness measures the net value of habitat available to bears after taking into account the disturbance effects of human land uses (Weaver et al. 1986). Methods used to assess habitat effectiveness for Kananaskis Country closely followed those of Gibeau et al. (1996) for Banff National Park. Four steps were taken to measure habitat effectiveness for Bear Management Units (BMU) in Kananaskis Country. The first two 

(Delineate Bear Management Units and Assess potential habitat suitability of BMUs) are described above; the third and fourth are described below.

Integrate displacement component

The displacement component of the habitat effectiveness model relied on digital human activity maps generated by Alberta Environment officials. These maps used line, point and polygon data categorized into various use-level classes based on park visitation records, personal observation and interviews. These data were used as the basis for delineating the types and levels of human uses and their associated disturbance values. A major assumption of the human activity model is that it accurately reflects human use at a landscape scale (Gibeau et al. 1996). Other assumptions of the displacement routine are presented in the USDA Forest Service (1990) unified CEM.

Mapped human activity features were classified according to: 1) motorized or nonmotorized activity; 2) point, linear or dispersed activity; 3 ) high or low intensity activity; and, 4) cover or non-cover security class. Point activity included campgrounds, lodges and other developments. Linear activity included highways, powerlines, and trails. An example of dispersed activity are high use portions of the McLean Creek ATV area. High use was defined as $>100$ vehicles or people/month, and low use were defined as $<100$ vehicles or people/month. Cover or non-cover designations were assigned to the Level 4 habitat map units and were based in part on empirical cover measures from Level 1 field sampling plots.

Each activity group was assigned a zone of influence and associated disturbance coefficient. The zone of influence identified the area in which grizzly bears would be affected by the activity. Based on previous research, a zone of human influence (buffer) of $800 \mathrm{~m}$ was used for motorized access roads, and $400 \mathrm{~m}$ for non-motorized access roads. The disturbance coefficient identified the degree of disturbance within the zone of influence. For comparison purposes, the zones of influence and disturbance coefficients were adopted from those first identified for the Yellowstone Ecosystem (Weaver et al. 1986) and later used for the Banff Bow Valley Study (Gibeau et al. 1996).

Disturbance coefficients were rated on a scale of 0 to 1.0 based on suspected response of bears to a given activity type and level. A disturbance coefficient of 0 implies total displacement from the zone of influence. A disturbance coefficient of 1.0 predicts no disturbance and implies that a bear's accessibility to the habitat in the zone of influence is not affected by the activity. A coefficient of 0.5 indicates that an area's ability to support bears is at $50 \%$ of its potential. That is, either half of the bears have been displaced or all the bears can use the area only half of the time (Gibeau et al. 1996).

\section{Habitat effectiveness}

The digital human activity features and their associated zones of influence were overlain onto habitat maps. The amount of habitat effectively displaced by these features was calculated using formulas outlined in the USDA Forest Service (1990) CEM.

Disturbance coefficients within overlapping zones of influence were considered to be cumulative and hence were multiplied. Habitat effectiveness values were calculated as the 

percentage (between 0 and 100) of realized habitat compared to the potential habitat for the BMU.

\section{Grizzly bear security areas in Kananaskis Country}

\section{Methods}

Much of the basis for security area analysis relies upon defining the average daily foraging radius and subsequent daily area requirements for an adult female grizzly bear. We use radio telemetry data from intensive tracking of wary adult female bears gathered between 1994 - 1997 by the Eastern Slopes Grizzly Bear Project (Gibeau and Herrero In press) to establish a mean daily movement distance. These data were calculated from the net linear distance of $>2$ relocations per day and do not reflect total distance travelled over the course of a day which may be much greater. The calculated average daily foraging radius among all bears sampled is one half of the mean daily movement distance. Subsequently, the minimum daily area requirement is simply the area of a circle $\left(\mathrm{Xr}^{2}\right)$ based on the daily foraging radius.

Several types of geographic information were compiled for analysis in MapInfo Professional@ (MapInfo Corp., Troy, NY) and Idrisi ${ }^{\circledR}$ (Clark Univ., Worcester, MA ) GIS systems including:

1. Elevation - A 1:250,000 scale digital elevation model compiled from National Topographic System series maps was used to derive an elevation cut at $2400 \mathrm{~m}$. That elevation was the upper limit of useful grizzly bear foraging through analysis of the grizzly bear habitat model (Kansas and Riddell 1995) and included $>99 \%$ of 5315 grizzly bear telemetry locations from the Eastern Slopes Grizzly Bear Project.

2. Landscape characteristics - A classified Landsat Thematic Mapper image (Komex International 1995) was used to derive a layer representing vegetated area. The unsuitable cover types of snow and ice, rock and bare soil, and water were reclassified out of the image leaving the area actually available to bears for potential foraging.

3. Human activity - Updated human activity data from Central Rockies Ecosystem Atlas (Komex International 1995) used in the habitat effectiveness model (Gibeau 1998) formed the basis of this layer. The most recent data available from all 4 jurisdictions were compiled into a single map of human activity across the Central Canadian Rocky Mountains. These maps categorized vector, point, and polygon data of all motorized roads, trails and facilities into high and low use (USDA Forest Service 1990, Gibeau 1998) based on visitation records and expert opinion. These data became the basis for delineation of the types and intensity of human uses and their associated disturbance values. Historical human use maps for Kananaskis Country and Banff National Park were compiled from circa 1950 records and personal interviews (Banff-Bow Valley Study 1996, S. Donelon pers. comm.). Future human activity projections for Kananaskis Country were based on a build out scenario from the existing recreational policy and a 6\% growth rate for Banff National Park (Banff-Bow Valley Study 1996). The major assumption of the human activity maps is that they accurately reflects human use at an ecosystem scale. 



\section{Analysis}

The initial stage of GIS analysis was to remove areas from the landscape that were unsuitable for foraging for bears. This was accomplished by combining the vegetated cover map with the $2400 \mathrm{~m}$ elevation cut. All lands either below $2400 \mathrm{~m}$ and/or vegetated were considered available lands for security areas.

Next, all high human use features for the various time periods were buffered by a $500 \mathrm{~m}$ zone of influence following Puchlerz and Servheen (1994). We consider this a conservative zone of human influence in comparison to research results from Yellowstone National Park (Mattson et al. 1987, Reinhart and Mattson 1990, Mattson et al. 1992, Green et al. 1997). Once the buffered human use data were prepared, these files were imposed on the map of available/unsuitable lands. This removed all areas within the zone of influence from further consideration. Interim maps depicting habitat patches of all sizes were generated once the area of available landscape outside the zone of influence had been determined.

The minimum daily area requirement for an adult female grizzly bear was then applied to maps of available land outside the zone of influence. All polygons smaller than the minimum daily area requirement for an adult female grizzly bear were eliminated from further consideration. For each jurisdiction, a tabulation of the land base in security area, unsuitable landscape, and land within the zone of human influence including polygons smaller than the minimum daily area requirement, were prepared. Historical and future scenarios for Kananaskis Country and Banff National Park were prepared in the same manner.

We used the program CALHOME (Kie et al. 1996) to calculate multi-annual 95\% adaptive kernal home ranges (Worton 1989) for 20 adult female grizzly bears (15 from the Eastern Slopes Study and 5 from the West Slopes Study). We chose the $95 \%$ isopleth to measure potential female grizzly bear occupancy but exclude short-term forays. The home range polygons were then converted to GIS map layers. For each adult female home range, a tabulation of the land base in security area, unsuitable landscape, and land within the zone of human influence including polygons smaller than the minimum daily area requirement, were prepared for the current time period only.

Pearson correlation coefficient and regression analysis were used to investigate the degree of association between home range size, percent of the land base in security area, percent unsuitable land, and percent of the land within the zone of human influence (SAS Inst. 

Inc., Cary, NC). Home range size was $\log _{\mathrm{n}}$ transformed before analysis to normalize the data. 



\section{APPENDIX B: ECOLOGICAL CHARACTERISTICS BY BEAR MANAGEMENT UNIT (BMU)}

As is outlined by Gibeau et al. (1996), BMUs were delineated on the basis of topographic features, human facilities and known high bear use areas. BMUs range in size from 20,590 to 46,283 hectares. Each unit is characterized by a particular assortment of physical elements and vegetation types. These ecological landscape features are outlined below.

\section{$\underline{\text { Cataract BMU }}$}

This unit consists of 34,175 ha located in the southern portion of K-Country, west of the McConnell thrust fault. Drainages in this unit include the Wilkinson, Cummings, Lost, Etherington and Baril Creeks. Fitzsimmons Creek and the Highwood River are located along the northern boundary of the BMU. Lower slopes of this unit are characterized by a veneer of morainal deposits with a variety of textures, while upper slopes consist of colluvial materials and thin soils. River valleys and creek beds vary in the composition of surficial materials from glaciofluvial sediments to course morainal debris. The Cataract BMU is characterized by the Alpine and Subalpine ecoregions and consists of $36 \%$ Lodgepole Pine forest, 37\% White and Englemann Spruce forest and 11\% barren rock. Roughly $6 \%$ of the unit is represented by mid to high elevation grasslands (above 1600 $\mathrm{m}$ ) and approximately $1 \%$ is shrub-dominated wetland. Clearcuts represent roughly $4 \%$ of the unit and the majority are characterized by consistent tree cover.

\section{$\underline{\text { Trap BMU }}$}

This unit consist of 20,590 ha and includes a portion of the Highwood Range west of the McConnell thrust fault. The Trap creek drainage is part of this unit and includes Head Creek and Wileman Creek. The Deep, Marston, Fir and Stoney Creeks drain into Highwood River along the southern edge of the unit while the Sullivan drainage meets the Highwood further north. Both Alpine and Subalpine zones are represented and are characterized by a veneer of colluvial materials. The eastern edge of the unit is considered Montane and is characterized by a veneer of morainal deposits. The Aspen Parkland Ecoregion is represented within the Trap and Sullivan Drainages where surfaces materials include glaciofluvial sediments. The most prominent forest cover type is Lodgepole Pine consisting of 39\% of the region. White and Englemann Spruce forests make up $15 \%$ of the unit while another $15 \%$ is represented by barren rock. The majority of the remaining landscape consists of 10\% mid-elevation grassland (1600-2200 m), 9\% Aspen forest, $2 \%$ wetland, and $4 \%$ mixed-wood forests.

\section{Spray BMU}

This unit consists of 29,556 ha located west of the McConnell thrust fault and includes the Spray Reservoir and a portion of the Goat Range and the Spray Mountains. Drainages include the Goat, Spurling, Buller, Smuts and Watridge Creeks. The unit is predominantly Alpine with an abundance of colluvial materials and bedrock equating to a 

figure of $41 \%$ barren rock. Forest cover consists of $23 \%$ White and Englemann Spruce and 20\% Lodgepole Pine. Lakes and ponds, including the Spray Reservoir, make up $7 \%$ of the landscape. The majority of the remaining area consists of roughly $2 \%$ steeply sloping shrubland, $1 \%$ wetland and $1 \%$ grassland. Another $3 \%$ of the landscape is represented by clearcuts with consistent tree cover and roughly $2 \%$ is made up of anthropogenic features that include reclamation sites, cropland, range clearings and other non-vegetated sites.

\section{$\underline{\text { Pekisko BMU }}$}

This unit consists of 23,210 ha of land that includes a portion of the Livingstone Ranges and is located east of the McConnell thrust fault. The unit includes within its boundaries a number of drainages: the Plateau, Cataract, Salter, North Twin, Wilkinson, Stimpson, Hay, Sheppard and Zephyr Creeks. The unit also includes the upper portion of the Livingstone River and the Pekisko drainage comprised of the Salt, Miller, Green Feed, Bear and Pekisko Creeks. The area is predominantly Subalpine and surficial deposits consist of a thin veneer of colluvial and morainal materials. Along the eastern boundary of the unit, localized areas of Aspen Parkland are found along valleys with sandy creek beds and morainal banks, while the surrounding lower foothill slopes are Montane and draped with morainal sediments. Forest cover in the unit consists of 35\% Lodgepole Pine, 18\% White and Englemann Spruce and 11\% Aspen forest. Another 17\% of the landscape consists of mid-elevation grassland $(1600-2200 \mathrm{~m})$ while only $6 \%$ consists of barren rock. Of the remaining area, roughly $4 \%$ is Balsam Poplar , $1 \%$ is shrubland and $1 \%$ is wetland.

\section{Highwood BMU}

This unit consists of 39,469 ha that includes a portion of Misty Range and is located west of the McConnell thrust. Cat Creek and Picklejar Creek drain from the Highwood range into the Highwood River that runs along the eastern boundary of the unit. Other drainages of the unit include the Mist, Storm, Odlum, Bishop, McPhail, Muir and Carnarvon Creeks. The area is predominantly Subalpine with a morainal veneer of variable texture. Twenty-two percent of the land base is represented by barren rock in the Alpine zone. Lodgepole Pine forests are extensive consisting of $35 \%$ of the landscape. The majority of the remaining area consists of roughly $9 \%$ mid-elevation grassland (1600-2200 m), 2\% Subalpine Fir, $1 \%$ shrub-dominated wetlands, and $2 \%$ clearcuts with consistent tree cover.

\section{Lower Kananaskis BMU}

This unit consists of 38,806 ha of land west of the McConnell thrust, including the Barrier Dam. The Evan Thomas, Ribbon, North Ribbon, Marmot and Lorette Creeks drain into the Kananaskis River within the unit that also includes the Upper Wind and Pigeon Creeks. A number of alluvial fans and abandoned river channels contribute to the diversity of landscape features in the area. The unit represents a mix of Alpine and Subalpine zones with a veneer of morainal deposits. The north-east corner of the unit consists of patches of Montane with morainal features and some glaciofluvial materials. 

Forest cover types of the unit consist of 26\% Lodgepole Pine and 23\% White and Englemann Spruce with approximately $37 \%$ of the landscape represented by barren rock. The majority of the remaining area consists of $2 \%$ Aspen forest, $2 \%$ coniferous mixedwood and $2 \%$ steeply-sloping shrublands. Roughly $2 \%$ of the unit is represented by anthropogenic features that include reclamation sites, cropland, rangeland clearings and other non-vegetated sites.

\section{$\underline{\text { Sheep BMU }}$}

This unit consists of 46,282 ha and includes ecological regions on both sides of the McConnell thrust fault. The unit includes within its boundaries the Sheep river as well as the following creeks: Coal, North Coal, Wolf, Dyson, March, Gorge, Junction, Cliff, Burns, Rae, and Blue Rock. Much of the area consists of Alpine and Subalpine zones where surface materials consist of colluvial and morainal debris. In the eastern portion of the unit, the Boreal Foothills zone is represented, while Aspen Parkland areas are found within river valleys. These river valleys vary from deep confined channels to single meanders, stretches of which consist of glaciofluvial materials. Lodgepole Pine forests are extensive, comprising $42 \%$ of the unit. An additional $15 \%$ of the landscape is represented by White and Englemann Spruce, while 25\% of the unit is barren rock. The majority of the remaining vegetative cover consists of 7\% Aspen forest, 3\% Lodgepole Pine mixed-wood and 3\% low to mid-elevation grassland (up to $2200 \mathrm{~m}$ ).

\section{$\underline{\text { Galatea BMU }}$}

This unit consists of 30,190 ha that include the Upper and Lower Kananaskis Lakes as well as a portion of the Opal, Kananaskis and Fisher mountain ranges west of the McConnell thrust fault. Drainages include the following creeks: Rocky, Galatea, Grizzly, Hood, King, Pocaterra, Opal, Elpoca, Boulton, Fox, Sarrail and Rawson. The Kananaskis River is also a component of this unit. A number of incised creeks and alluvial fans contribute to the diversity of ecological features. A mix of Alpine and Subalpine zones dominate the landscape with surficial materials consisting of colluvial and morainal veneers. The unit is represented by $33 \%$ barren rock while forest cover includes $23 \%$ Lodgepole Pine, 26\% White and Englemann Spruce, and 2\% Subalpine Fir. The majority of the remaining vegetative cover consists of $4 \%$ moderate and steeply sloping shrubland, $2 \%$ mid-elevation grassland (1600-2200) and $1 \%$ wetland. 5\% of the landscape consists of ponds and lakes while another $2 \%$ includes rangeland clearings and other non-vegetated anthropogenic features.

\section{Upper Kananaskis BMU}

This unit consists of 27,664 ha of predominantly Alpine area that includes the Spray Mountains and Kananaskis Range west of the McConnell thrust fault. Drainages include the Upper Kananaskis River and the following creeks: Smith-Dorrien, Waspite, Murray, James Walker, Headwall, Chester, French, Burstall, Kent, Gypsum, Three Isles, Aster and Foch. Colluvial materials and bedrock make up a substantial component of the unit equating to a value of 53\% barren rock for the unit. An additional 5\% consists of snow and ice. Forested cover is represented by $23 \%$ White and Englemann Spruce, $4 \%$ 

Lodgepole Pine, and 3\% Subalpine Fir. The majority of the remaining vegetative cover includes $4 \%$ shrubland on moderate to steep slopes and $4 \%$ clearcuts with consistent tree cover.

\section{Upper Elbow BMU}

This unit consists of 36,223 ha of land along the McConnell thrust fault. Drainages in the region include the upper Elbow and little Elbow rivers, as well as the Cougar, Glasgow, South Glasgow, Shoulder and Nihahi Creeks. The unit is predominantly Alpine with surface materials consisting of colluvium and bedrock. Fifty-four percent of the unit is represented by barren rock. Forest cover types include 21\% White and Englemann Spruce, $16 \%$ Lodgepole Pine and 2\% Subalpine Fir. $4 \%$ of the unit consists of shrubland on gentle to moderately steep slopes and roughly $2 \%$ consists of mid-elevation grassland (1600-2200 m).

\section{Threepoint BMU}

This unit consists of 32,443 ha of land east of the McConnell thrust fault. Drainages within the unit include Ware, Link, Death Valley, Threepoint, Muskeg, Rock and Volcano Creeks. The region is characterized by Subalpine conditions to the west and Boreal Foothills to the east. Aspen Parkland is a feature of the Threepoint and Ware drainages along the eastern boundary of the unit. Surficial materials of the region consist of colluvial and morainal veneers of variable textures as well as localized deposits of glaciolacustrine sediments. Lodgepole Pine forest is extensive and represents $52 \%$ of the landscape. Other forest types include 12\% White and Englemann Spruce and 14\% Aspen. The majority of other vegetation types of the unit include 5\% coniferous mixedwood, 4\% mid-elevation grassland (1600-2200), 4\% shrub-dominant wetland and $1 \%$ Balsam Poplar. Barren rock comprises $2 \%$ of the area while clearcuts dominated by graminoids represent $2.5 \%$ of the landscape.

\section{Lower Elbow BMU}

This unit consists of 41,289 ha, the majority of which is located east of the McConnell thrust fault and includes a portion of the Fisher Range. Drainages within the unit include the Elbow River as well as the following creeks: Iron, McLean, Silvester, Quirk, Powderface, Prairie, trail, Bragg, Ranger, Moose Dome, Moose Mountain and Canyon. The majority of the region consists of high foothills and mountain slopes of the Subalpine zone with colluvial and morainal veneer. The Boreal Foothills zone is represented along the eastern edge of the unit where colluvial and morainal deposits are prominent and glaciolacustrine deposits are found in localized areas. The dominant forest cover type is Lodgepole Pine, comprising 55\% of the landscape. Other forest types include 14\% White and Englemann Spruce, 4\% Aspen and 3\% pine mixed-wood. The majority of the remaining cover types include $2 \%$ shrubland on gentle slopes, $2 \%$ mid-elevation grassland (1600-2200 m) and 3\% shrub-dominant wetland. Twelve percent of the unit consists of barren rock. 



\section{Jumpingpound BMU}

This unit consists of 24,397 ha of land located east of the McConnell thrust fault. Drainages in the unit include the following creeks: Jumpingpound, Moose, Cox Hill, Sibbald, Lusk and Bateman. The unit is predominantly Subalpine with localized areas of Alpine conditions at Jumpingpound Mountain and Cox Hill. The Boreal Foothills zone is represented along the north-east edge of the unit, while Montane areas are located in the north-west. Morainal and Colluvial veneers characterize the area with some glaciofluvial deposits along drainages to the east. Lodgepole Pine forest is the dominant vegetation cover representing $58 \%$ of the landscape while $16 \%$ of the unit consists of White and Englemann Spruce. The majority of the remaining vegetation consists of $4 \%$ Aspen forest, $2 \%$ pine mixed-wood, $1 \%$ shrubland on gentle slopes, $1 \%$ mid-elevation grassland $(1600-2200 \mathrm{~m})$, and $1 \%$ shrub-dominated wetland. Another $5 \%$ of the landscape is represented by barren rock, while clearcuts make up 7\% (4\% grass dominant and 3\% with consistent tree cover). 

APPENDIX C: HIERARCHICAL LAND COVER MAPPING FOR KANANASKIS COUNTRY AND REGION 

Level 1 Land Cover Classes

1. Arthropogenic

2. Upland Forest

3. Upland Shrub

4. Upland Herbaceous

5. Wetland and Water

6. Barren land

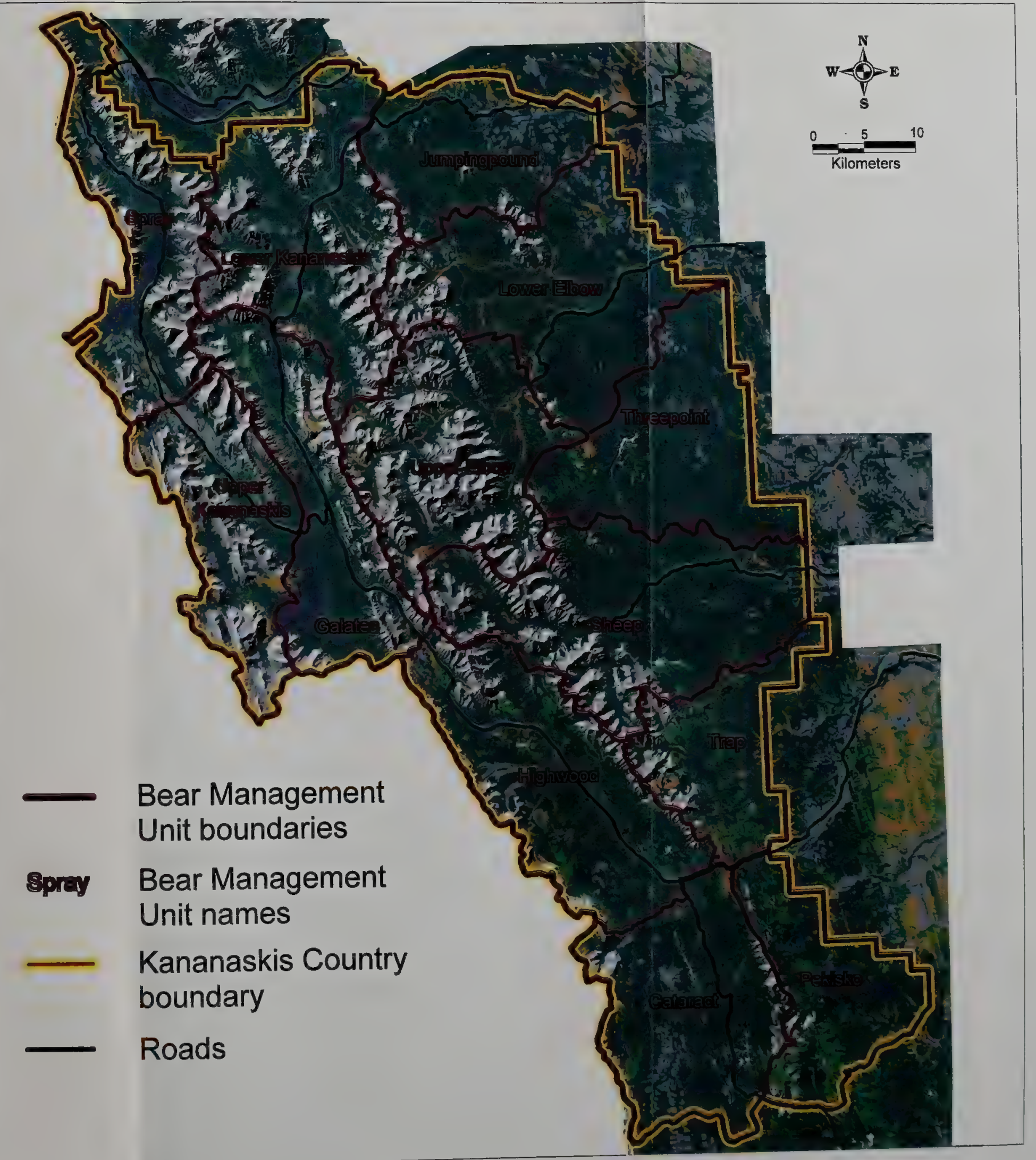




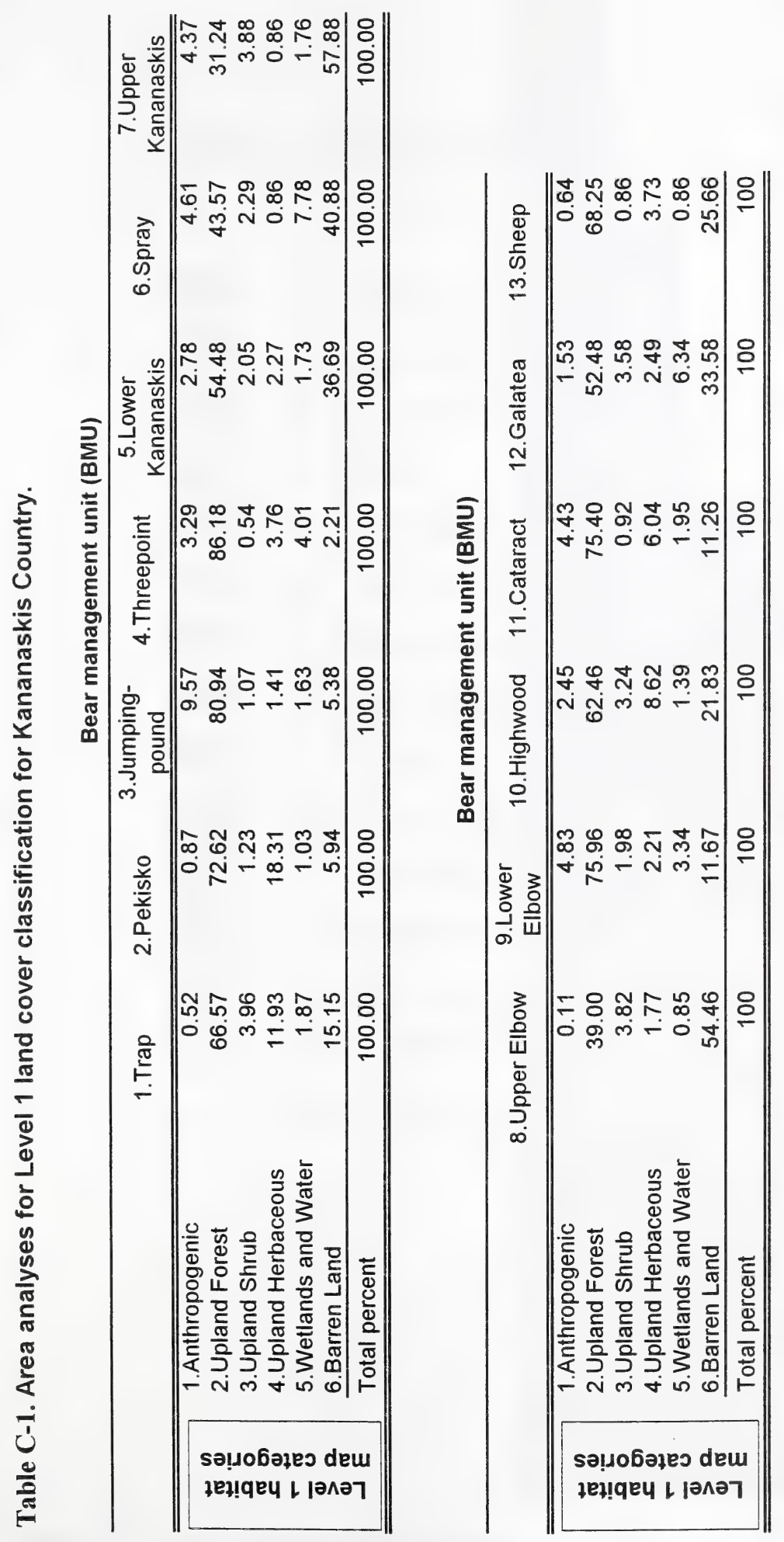



\section{Level 2 Land Cover Classes}

1. Urban and Industrial

2. Agriculture

3. Forestry Clearcuts

4. Burns

5. Coniferous Forest

6. Deciduous Forest

7. Mixedwood Forest

8. Shrubland

9. Grassland

10. Forb Meadow

11. Wetlands

12. Waterbodies

IIy 13. Barren Rock

14. Cutbank/Sand

15. Permanent Snow/lce

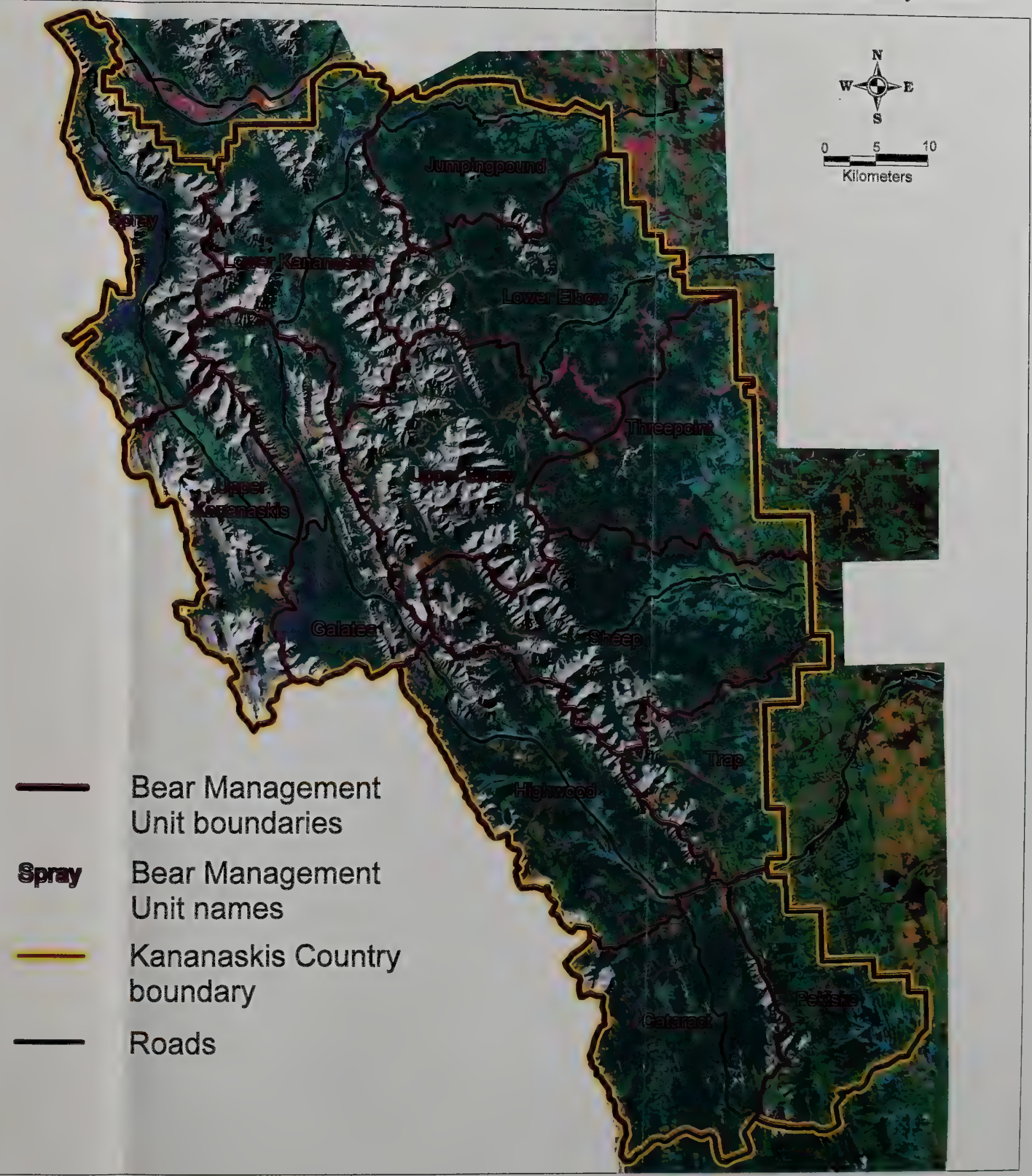

Map C-2. Level 2 land cover classification for Kananaskis Country. 



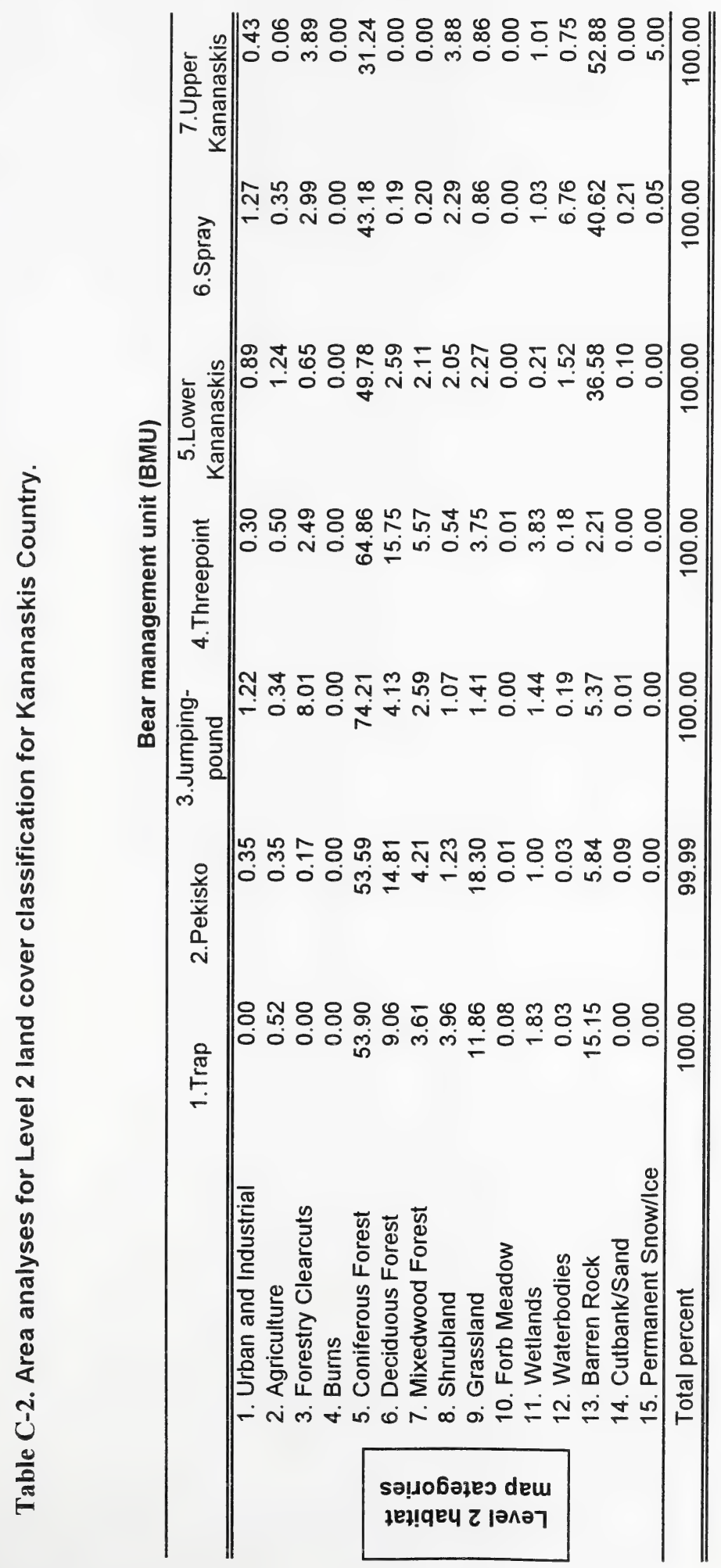





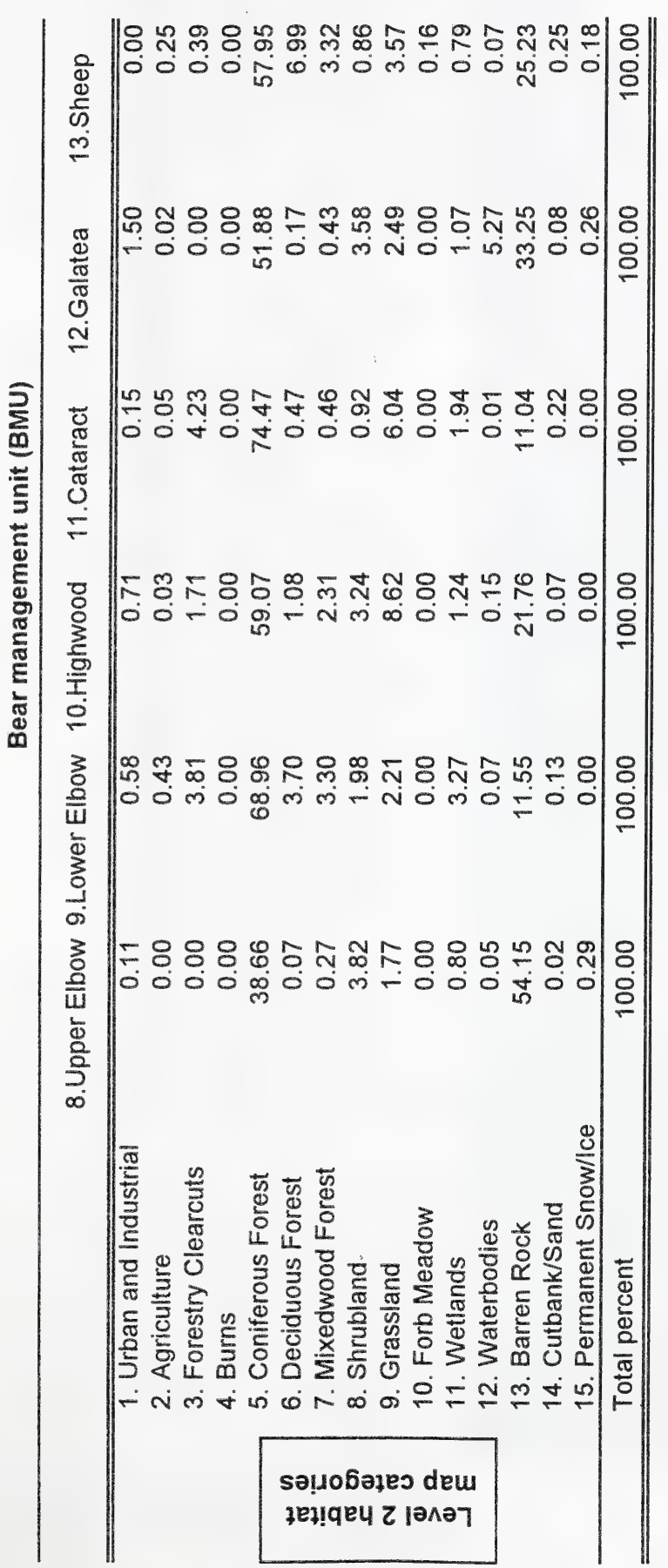





\section{Level 3 Land Cover Classes}

$\square$ 1. Anthropogenic (non-vegetated)

2. Reclamated (vegetated)

3. Cropland

4. Rangeland Clearing

5. Improved Pasture/Mived Shrub

6. Clearcuts [Graminoid Dominated]

7. Cleareuts (Shrub/Sapling Dom

8. Clearouts [Tree Dominated]

9. Clearculs (Undifferentiont)

10. Bumns (Graminoid Dominated)

11. Bums (Grab/Sapominated)

12. Burns [Tree Dominated]

13. Burns (Undifferentiated)

14. Lodgepole Pine

15. White and Engleman Spruce

16. Subalpine F

17. Douglas Fir

18. Whilebark Pine

19. Subalpine Lareh

20. Aspen

21. Balsam Poplar

22. Aspen Mixedwood

23. Pine Mikedwood

24. Spruce Mizedwoed

25. Shrubland (Level-Gentle slope)

27. Shrubland (Steep slope)

28. Grassland (Elevation $<1600 \mathrm{~m}$

29. Grassland [Elevation 1600 ?

30. Graseland (Elovation $>23$

31. Forb Meadow

32. Wetland (Treed)

33. Wetland (Shrub)

34. Welland [Grminoid]

35. Rivers

36. Lakes/Ponds

37. Flaoded Areas

38. Rack (Barren)

39. Cutbank/Sand

40. Permanent Snow/lce

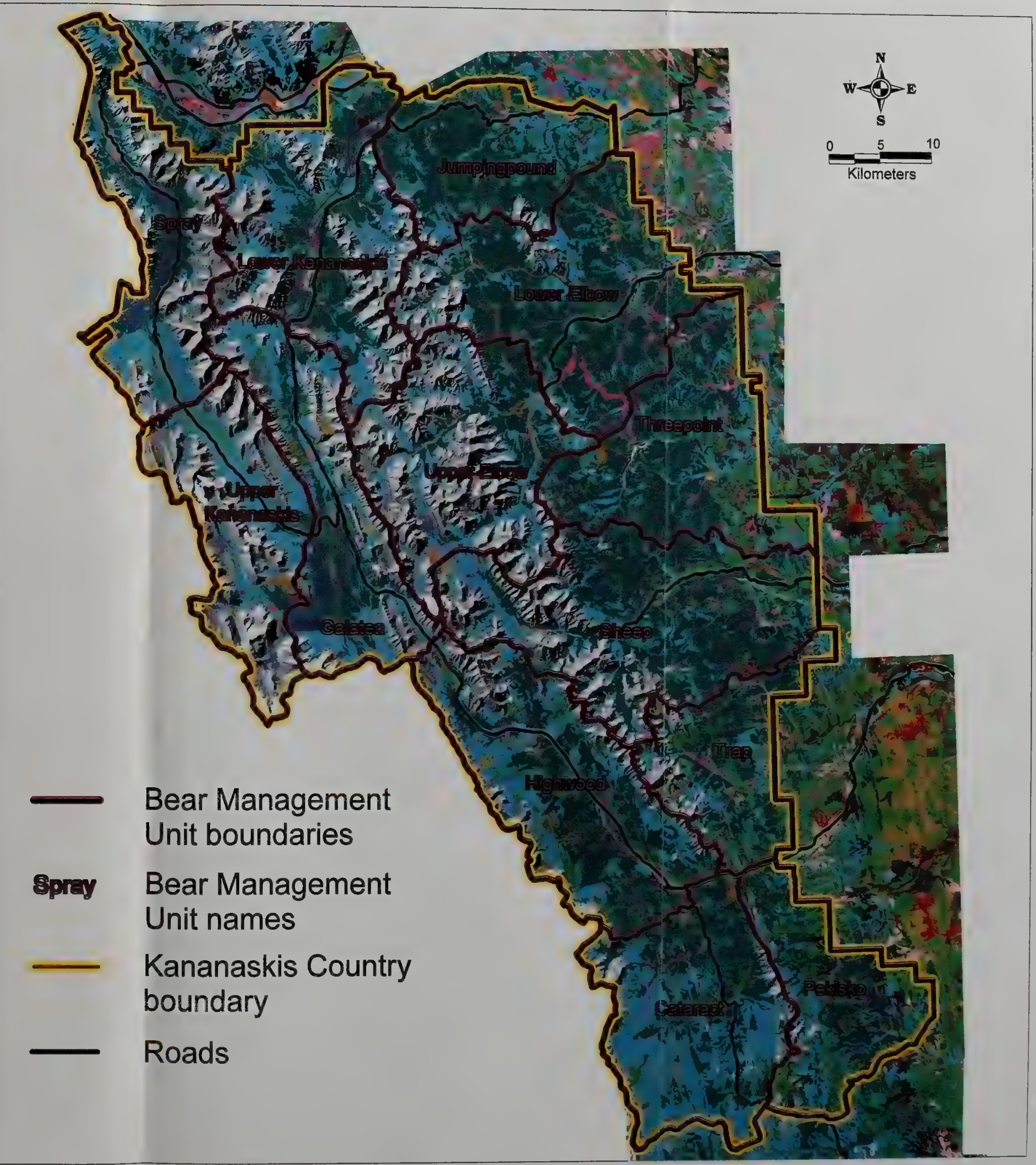

Map C-3. Level 3 land cover classification for Kananaskis Country. 

Table C-3. Area analyses for Level 3 land cover classification for Kananaskis Country.

Bear management units (BMUs)

\begin{tabular}{|c|c|c|c|c|c|}
\hline & & 1.Trap & 2.Pekisko & $\begin{array}{l}\text { 3.Jumping- } \\
\text { pound }\end{array}$ & 4.Threepoint \\
\hline \multirow{8}{*}{ 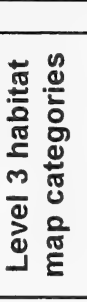 } & 1. Anthropogenic (non-vegetated) & 0.00 & 0.35 & 1.22 & 0.30 \\
\hline & 2. Reclamated (vegetated) & 0.02 & 0.04 & 0.01 & 0.08 \\
\hline & 3. Cropland & 0.01 & 0.19 & 0.01 & 0.07 \\
\hline & 4. Rangeland Clearing & 0.48 & 0.12 & 0.32 & 0.27 \\
\hline & 5. Improved Pasture/Mixed Shrub & 0.00 & 0.00 & 0.00 & 0.08 \\
\hline & 6. Clearcuts (Graminoid Dominated) & 0.00 & 0.02 & 4.21 & 1.28 \\
\hline & 7. Clearcuts (Shrub/Sapling Dominated) & 0.00 & 0.01 & 0.62 & 0.25 \\
\hline & 8. Clearcuts (Tree Dominated) & 0.00 & 0.14 & 3.17 & 0.96 \\
\hline \multirow{33}{*}{ - } & 9. Clearcuts (Undifferentiated) & 0.00 & 0.00 & 0.00 & 0.00 \\
\hline & 10. Burns (Graminoid Dominated) & 0.00 & 0.00 & -0.00 & 0.00 \\
\hline & 11. Burns (Shrub/Sapling Dominated) & 0.00 & 0.00 & 0.00 & 0.00 \\
\hline & 12. Burns (Tree Dominated) & 0.00 & 0.00 & 0.00 & 0.00 \\
\hline & 13. Burns (Undifferentiated) & 0.00 & 0.00 & 0.00 & 0.00 \\
\hline & 14. Lodgepole Pine & 38.08 & 34.90 & 57.96 & 52.47 \\
\hline & 15. White and Engleman Spruce & 14.84 & 18.10 & 16.25 & 12.26 \\
\hline & 16. Subalpine Fir & 0.43 & 0.21 & 0.02 & 0.14 \\
\hline & 17. Douglas Fir & 0.00 & 0.00 & 0.00 & 0.00 \\
\hline & 18. Whitebark Pine & 0.00 & 0.36 & 0.00 & 0.00 \\
\hline & 19. Subalpine Larch & 0.57 & 0.04 & 0.00 & 0.00 \\
\hline & 20. Aspen & 8.83 & 10.91 & 4.05 & 14.32 \\
\hline & 21. Balsam Poplar & 0.23 & 3.90 & 0.09 & 1.44 \\
\hline & 22. Aspen Mixedwood & 0.04 & 0.09 & 0.00 & 0.14 \\
\hline & 23. Pine Mixedwood & 1.67 & 2.95 & 1.67 & 3.16 \\
\hline & 24. Spruce Mixedwood & 1.89 & 1.18 & 0.93 & 2.27 \\
\hline & 25. Shrubland (Level-Gentle slope) & 0.66 & 0.62 & 0.68 & 0.10 \\
\hline & 26. Shrubland (Moderate slope) & 1.78 & 0.58 & 0.23 & 0.26 \\
\hline & 27. Shrubland (Steep slope) & 1.51 & 0.03 & 0.15 & 0.17 \\
\hline & 28. Grassland (Elevation <1600m) & 1.04 & 1.54 & 0.38 & 0.90 \\
\hline & 29. Grassland (Elevation $1600-2200 \mathrm{~m}$ ) & 10.24 & 11.94 & 1.02 & 2.67 \\
\hline & 30. Grassland (Elevation $>2200 \mathrm{~m}$ ) & 0.56 & 4.81 & 0.00 & 0.18 \\
\hline & 31. Forb Meadow & 0.08 & 0.01 & 0.00 & 0.01 \\
\hline & 32. Wetland (Treed) & 0.19 & 0.08 & 0.12 & 0.35 \\
\hline & 33. Wetland (Shrub) & 1.44 & 0.61 & 1.12 & 2.36 \\
\hline & 34. Wetland (Grminoid) & 0.20 & 0.31 & 0.20 & 1.11 \\
\hline & 35. Rivers & 0.00 & 0.00 & 0.01 & 0.00 \\
\hline & 36. Lakes/Ponds & 0.03 & 0.03 & 0.06 & 0.05 \\
\hline & 37. Flooded Areas & 0.00 & 0.00 & 0.12 & 0.14 \\
\hline & 38. Rock (Barren) & 15.15 & 5.84 & 5.37 & 2.21 \\
\hline & 39. Cutbank/Sand & 0.00 & 0.09 & 0.01 & 0.00 \\
\hline & 40. Permanent Snow/lce & 0.00 & 0.00 & 0.00 & 0.00 \\
\hline & Total percent & 100.00 & 100.00 & 100.00 & 100.00 \\
\hline
\end{tabular}



Table C-3. Area analyses for Level 3 land cover classification for Kananaskis Country.

Bear management units (BMUs)

\begin{tabular}{|c|c|c|c|c|}
\hline & & $\begin{array}{c}\text { 5.Lower } \\
\text { Kananaskis } \\
\end{array}$ & 6.Spray & $\begin{array}{c}\text { 7.Upper } \\
\text { Kananaskis } \\
\end{array}$ \\
\hline \multirow{41}{*}{ 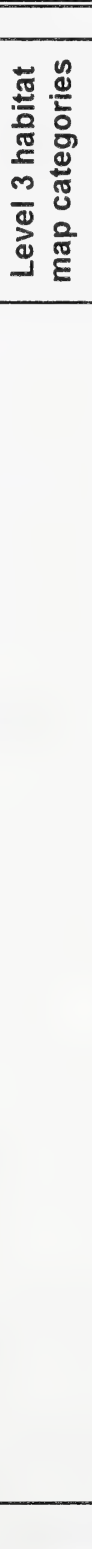 } & 1. Anthropogenic (non-vegetated) & 0.89 & 1.27 & 0.43 \\
\hline & 2. Reclamated (vegetated) & 0.56 & 0.09 & 0.00 \\
\hline & 3. Cropland & 0.36 & 0.01 & 0.00 \\
\hline & 4. Rangeland Clearing & 0.33 & 0.25 & 0.06 \\
\hline & 5. Improved Pasture/Mixed Shrub & 0.00 & 0.00 & 0.00 \\
\hline & 6. Clearcuts (Graminoid Dominated) & 0.01 & 0.00 & 0.00 \\
\hline & 7. Clearcuts (Shrub/Sapling Dominated) & 0.13 & 0.77 & 0.35 \\
\hline & 8. Clearcuts (Tree Dominated) & 0.50 & 2.22 & 3.44 \\
\hline & 9. Clearcuts (Undifferentiated) & 0.00 & 0.00 & 0.00 \\
\hline & 10. Burns (Graminoid Dominated) & 0.00 & 0.00 & 0.00 \\
\hline & 11. Burns (Shrub/Sapling Dominated) & 0.00 & 0.00 & 0.10 \\
\hline & 12. Burns (Tree Dominated) & 0.00 & 0.00 & 0.00 \\
\hline & 13. Burns (Undifferentiated) & 0.00 & 0.00 & 0.00 \\
\hline & 14. Lodgepole Pine & 25.77 & 19.61 & 4.40 \\
\hline & 15. White and Engleman Spruce & 22.86 & 22.90 & 22.74 \\
\hline & 16. Subalpine Fir & 0.77 & 0.17 & 3.37 \\
\hline & 17. Douglas Fir & 0.26 & 0.26 & 0.00 \\
\hline & 18. Whitebark Pine & 0.00 & 0.00 & 0.00 \\
\hline & 19. Subalpine Larch & 0.14 & 0.25 & 0.76 \\
\hline & 20. Aspen & 2.35 & 0.19 & 0.00 \\
\hline & 21. Balsam Poplar & 0.24 & 0.00 & 0.00 \\
\hline & 22. Aspen Mixedwood & 0.00 & 0.00 & 0.00 \\
\hline & 23. Pine Mixedwood & 1.87 & 0.04 & 0.00 \\
\hline & 24. Spruce Mixedwood & 0.24 & 0.16 & 0.00 \\
\hline & 25. Shrubland (Level-Gentle slope) & 0.67 & 0.66 & 0.30 \\
\hline & 26. Shrubland (Moderate slope) & 0.58 & 0.76 & 1.42 \\
\hline & 27. Shrubland (Steep slope) & 0.79 & 0.86 & 2.15 \\
\hline & 28. Grassland (Elevation $<1600 \mathrm{~m}$ ) & 1.26 & 0.01 & 0.00 \\
\hline & 29. Grassland (Elevation $1600-2200 \mathrm{~m}$ ) & 0.87 & 0.67 & 0.67 \\
\hline & 30. Grassland (Elevation $>2200 \mathrm{~m}$ ) & 0.13 & 0.18 & 0.19 \\
\hline & 31. Forb Meadow & 0.00 & 0.00 & 0.00 \\
\hline & 32. Wetland (Treed) & 0.03 & 0.40 & 0.17 \\
\hline & 33. Wetland (Shrub) & 0.11 & 0.33 & 0.57 \\
\hline & 34. Wetland (Grminoid) & 0.07 & 0.30 & 0.28 \\
\hline & 35. Rivers & 0.48 & 0.00 & 0.00 \\
\hline & 36. Lakes/Ponds & 0.91 & 6.71 & 0.72 \\
\hline & 37. Flooded Areas & 0.12 & 0.05 & 0.03 \\
\hline & 38. Rock (Barren) & 36.59 & 40.62 & 52.88 \\
\hline & 39. Cutbank/Sand & 0.10 & 0.21 & 0.00 \\
\hline & 40. Permanent Snow/lce & 0.00 & 0.05 & 5.00 \\
\hline & Total percent & 100.00 & 100.00 & 100.00 \\
\hline
\end{tabular}



Table C-3. Area analyses for Level 3 land cover classification for Kananaskis Country.

Bear management units (BMUs)

\begin{tabular}{|c|c|c|c|c|}
\hline & & 8.Upper Elbow & 9.Lower Elbow & 10. Highwood \\
\hline \multirow{40}{*}{ 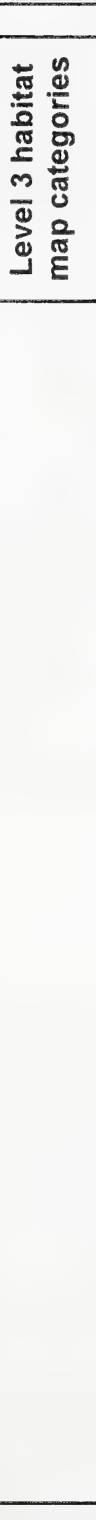 } & 1. Anthropogenic (non-vegetated) & 0.11 & 0.58 & 0.71 \\
\hline & 2. Reclamated (vegetated) & 0.00 & 0.05 & 0.01 \\
\hline & 3. Cropland & 0.00 & 0.16 & 0.00 \\
\hline & 4. Rangeland Clearing & 0.00 & 0.21 & 0.01 \\
\hline & 5. Improved Pasture/Mixed Shrub & 0.00 & 0.00 & 0.00 \\
\hline & 6. Clearcuts (Graminoid Dominated) & 0.00 & 1.99 & 0.00 \\
\hline & 7. Clearcuts (Shrub/Sapling Dominated) & 0.00 & 0.73 & 0.00 \\
\hline & 8. Clearcuts (Tree Dominated) & 0.00 & 1.09 & 1.71 \\
\hline & 9. Clearcuts (Undifferentiated) & 0.00 & 0.00 & 0.00 \\
\hline & 10. Burns (Graminoid Dominated) & 0.00 & 0.00 & 0.00 \\
\hline & 11. Burns (Shrub/Sapling Dominated) & 0.00 & 0.00 & 0.00 \\
\hline & 12. Burns (Tree Dominated) & 0.00 & 0.00 & 0.00 \\
\hline & 13. Burns (Undifferentiated) & 0.00 & 0.00 & 0.00 \\
\hline & 14. Lodgepole Pine & 15.52 & 55.38 & 34.76 \\
\hline & 15. White and Engleman Spruce & 21.26 & 13.58 & 21.65 \\
\hline & 16. Subalpine Fir & 1.79 & 0.03 & 2.05 \\
\hline & 17. Douglas Fir & 0.00 & 0.00 & 0.00 \\
\hline & 18. Whitebark Pine & 0.00 & 0.00 & 0.00 \\
\hline & 19. Subalpine Larch & 0.10 & 0.00 & 0.64 \\
\hline & 20. Aspen & 0.07 & 3.56 & 0.86 \\
\hline & 21. Balsam Poplar & 0.00 & 0.14 & 0.22 \\
\hline & 22. Aspen Mixedwood & 0.00 & 0.01 & 0.00 \\
\hline & 23. Pine Mixedwood & 0.27 & 2.75 & 1.98 \\
\hline & 24. Spruce Mixedwood & 0.00 & 0.54 & 0.33 \\
\hline & 25. Shrubland (Level-Gentle slope) & 1.75 & 0.89 & 0.87 \\
\hline & 26. Shrubland (Moderate slope) & 1.31 & 0.70 & 1.41 \\
\hline & 27. Shrubland (Steep slope) & 0.75 & 0.38 & 0.96 \\
\hline & 28. Grassland (Elevation $<1600 \mathrm{~m}$ ) & 0.00 & 0.38 & 0.18 \\
\hline & 29. Grassland (Elevation $1600-2200 \mathrm{~m}$ ) & 1.51 & 1.80 & 6.04 \\
\hline & 30. Grassiand (Elevation $>2200 \mathrm{~m}$ ) & 0.26 & 0.03 & 2.39 \\
\hline & 31. Forb Meadow & 0.00 & 0.00 & 0.00 \\
\hline & 32. Wetland (Treed) & 0.09 & 0.93 & 0.33 \\
\hline & 33. Wetland (Shrub) & 0.69 & 1.90 & 0.82 \\
\hline & 34. Wetland (Grminoid) & 0.02 & 0.44 & 0.09 \\
\hline & 35. Rivers & 0.00 & 0.01 & 0.00 \\
\hline & 36. Lakes/Ponds & 0.05 & 0.01 & 0.07 \\
\hline & 37. Flooded Areas & 0.00 & 0.04 & 0.09 \\
\hline & 38. Rock (Barren) & 54.15 & 11.55 & 21.76 \\
\hline & 39. Cutbank/Sand & 0.02 & 0.13 & 0.07 \\
\hline & 40. Permanent Snow/lce & 0.29 & 0.00 & 0.00 \\
\hline & Total percent & 100.00 & 100.00 & 100.00 \\
\hline
\end{tabular}



Table C-3. Area analyses for Level 3 land cover classification for Kananaskis Country.

Bear management units (BMUs)

\begin{tabular}{|c|c|c|c|c|}
\hline & & 11.Cataract & 12. Galatea & 13.Sheep \\
\hline \multirow{41}{*}{ 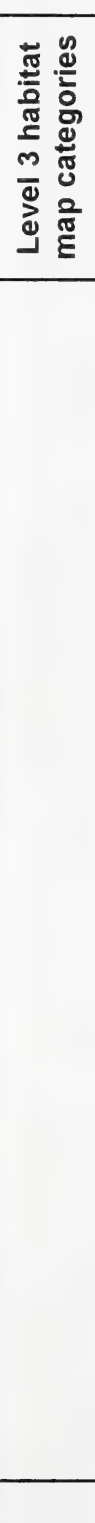 } & 1. Anthropogenic (non-vegetated) & 0.15 & 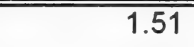 & 0.00 \\
\hline & 2. Reclamated (vegetated) & 0.04 & 0.00 & 0.00 \\
\hline & 3. Cropland & 0.00 & 0.00 & 0.09 \\
\hline & 4. Rangeland Clearing & 0.01 & 0.02 & 0.16 \\
\hline & 5. Improved Pasture/Mixed Shrub & 0.00 & 0.00 & 0.00 \\
\hline & 6. Clearcuts (Graminoid Dominated) & 1.37 & 0.00 & 0.10 \\
\hline & 7. Clearcuts (Shrub/Sapling Dominated) & 0.43 & 0.00 & 0.17 \\
\hline & 8. Clearcuts (Tree Dominated) & 2.43 & 0.00 & 0.11 \\
\hline & 9. Clearcuts (Undifferentiated) & 0.00 & 0.00 & 0.00 \\
\hline & 10. Burns (Graminoid Dominated) & 0.00 & 0.00 & 0.00 \\
\hline & 11. Burns (Shrub/Sapling Dominated) & 0.00 & 0.00 & 0.00 \\
\hline & 12. Burns (Tree Dominated) & 0.00 & 0.00 & 0.00 \\
\hline & 13. Burns (Undifferentiated) & 0.00 & 0.00 & 0.00 \\
\hline & 14. Lodgepole Pine & 36.27 & 22.90 & 41.71 \\
\hline & 15. White and Engleman Spruce & 37.30 & 26.38 & 14.98 \\
\hline & 16. Subalpine Fir & 0.29 & 2.07 & 1.02 \\
\hline & 17. Douglas Fir & 0.00 & 0.00 & 0.00 \\
\hline & 18. Whitebark Pine & 0.00 & 0.00 & 0.00 \\
\hline & 19. Subalpine Larch & 0.63 & 0.55 & 0.25 \\
\hline & 20. Aspen & 0.17 & 0.17 & 6.57 \\
\hline & 21. Baisam Poplar & 0.30 & 0.00 & 0.41 \\
\hline & 22. Aspen Mixedwood & 0.00 & 0.00 & 0.02 \\
\hline & 23. Pine Mixedwood & 0.26 & 0.22 & 2.73 \\
\hline & 24. Spruce Mixedwood & 0.20 & 0.21 & 0.56 \\
\hline & 25. Shrubland (Level-Gentle slope) & 0.12 & 0.54 & 0.29 \\
\hline & 26. Shrubland (Moderate slope) & 0.44 & 1.52 & 0.45 \\
\hline & 27. Shrubland (Steep slope) & 0.36 & 1.50 & 0.12 \\
\hline & 28. Grassland (Elevation $<1600 \mathrm{~m}$ ) & 0.24 & 0.01 & 1.24 \\
\hline & 29. Grassland (Elevation $1600-2200 \mathrm{~m}$ ) & 3.00 & 1.91 & 2.08 \\
\hline & 30. Grassland (Elevation >2200m) & 2.79 & 0.57 & 0.24 \\
\hline & 31. Forb Meadow & 0.00 & 0.00 & 0.16 \\
\hline & 32. Wetland (Treed) & 0.57 & 0.40 & 0.26 \\
\hline & 33. Wetland (Shrub) & 1.28 & 0.45 & 0.21 \\
\hline & 34. Wetland (Grminoid) & 0.09 & 0.22 & 0.31 \\
\hline & 35. Rivers & 0.00 & 0.23 & 0.00 \\
\hline & 36. Lakes/Ponds & 0.00 & 5.00 & 0.06 \\
\hline & 37. Flooded Areas & 0.00 & 0.03 & 0.01 \\
\hline & 38. Rock (Barren) & 11.04 & 33.25 & 25.23 \\
\hline & 39. Cutbank/Sand & 0.22 & 0.08 & 0.25 \\
\hline & 40. Permanent Snow/lce & 0.00 & 0.26 & 0.18 \\
\hline & Total percent & 100.00 & 100.00 & 100.00 \\
\hline
\end{tabular}





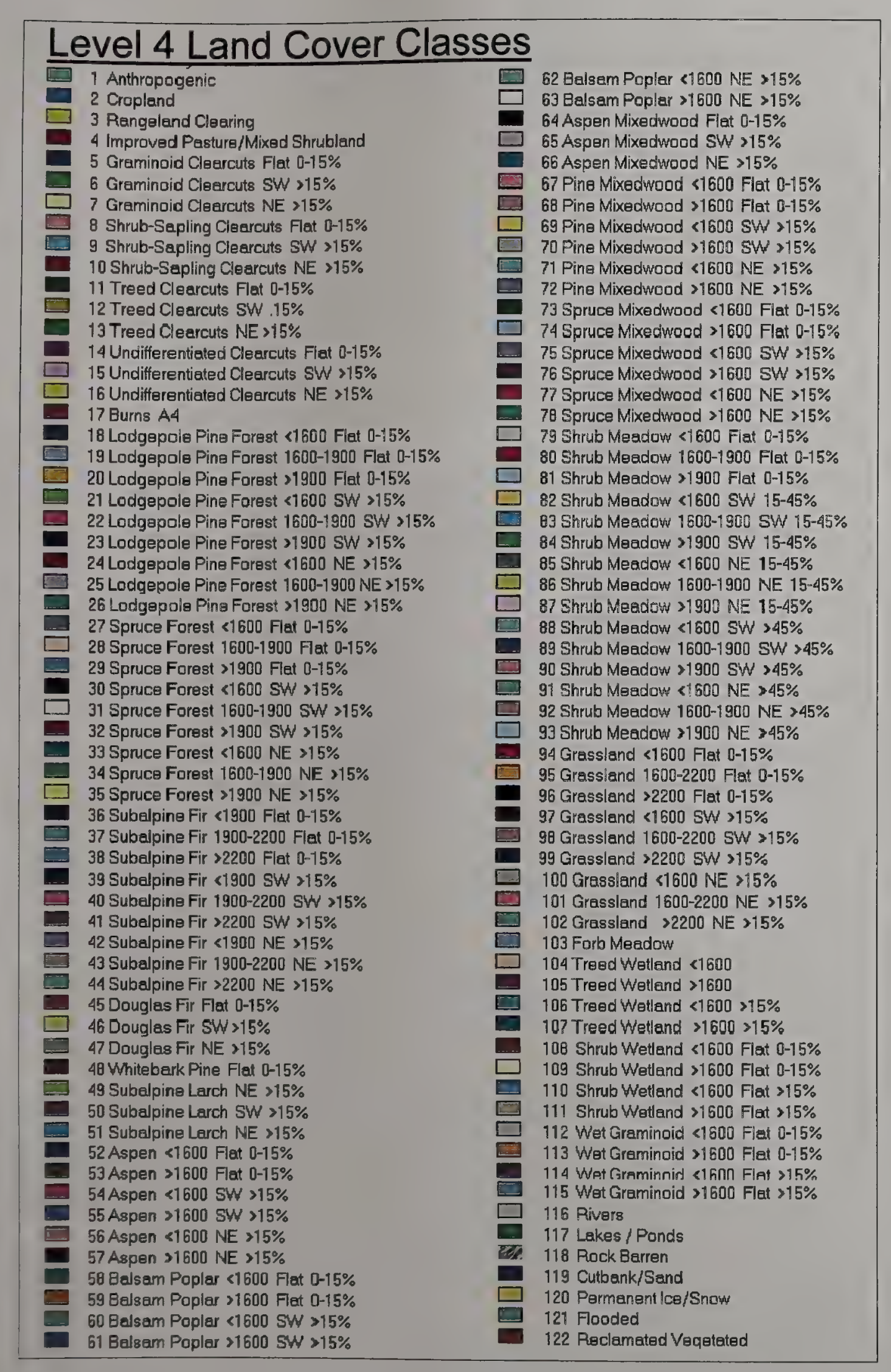

Grizzly Bear Status in K-Country * ESGBP

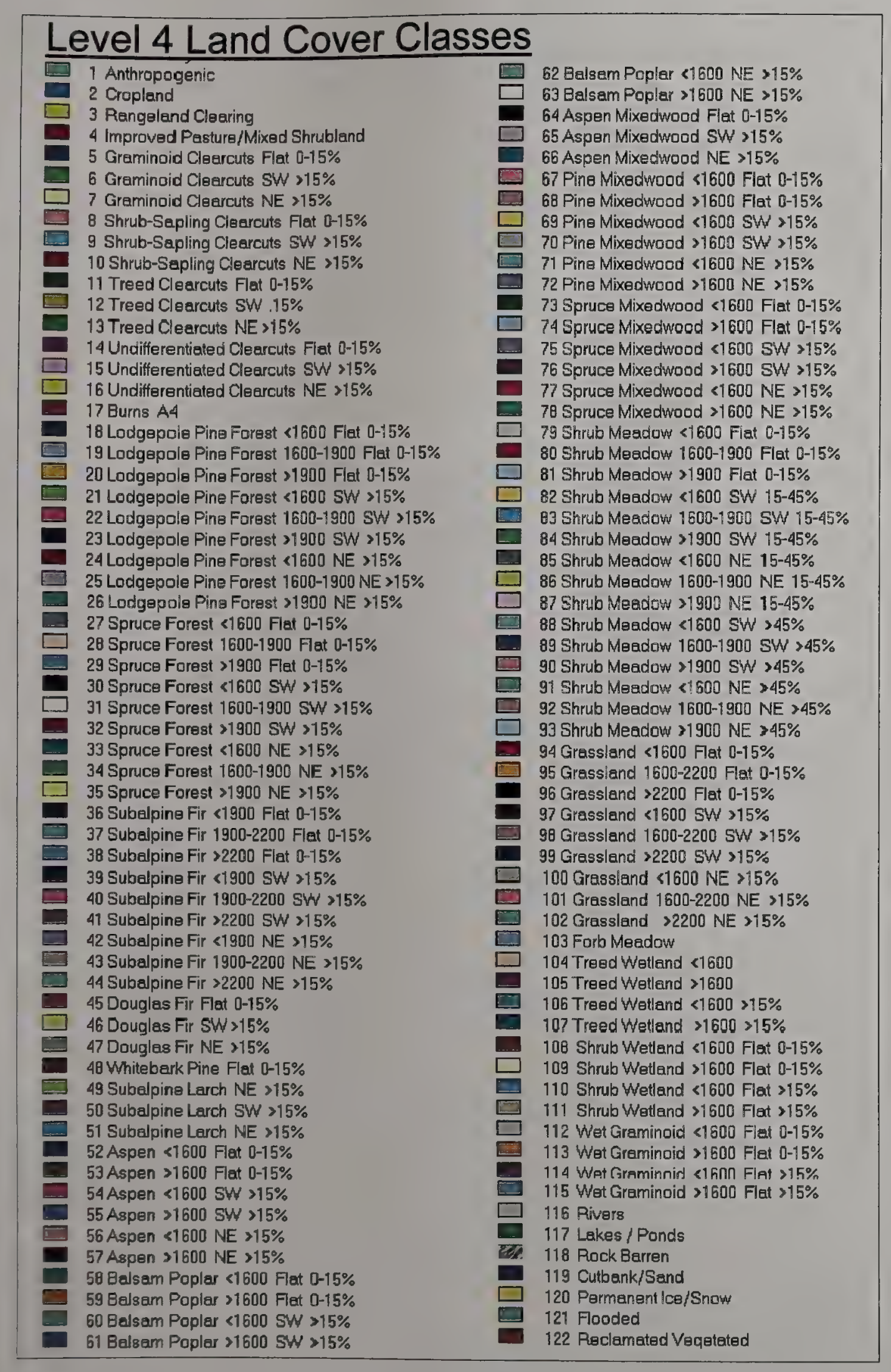

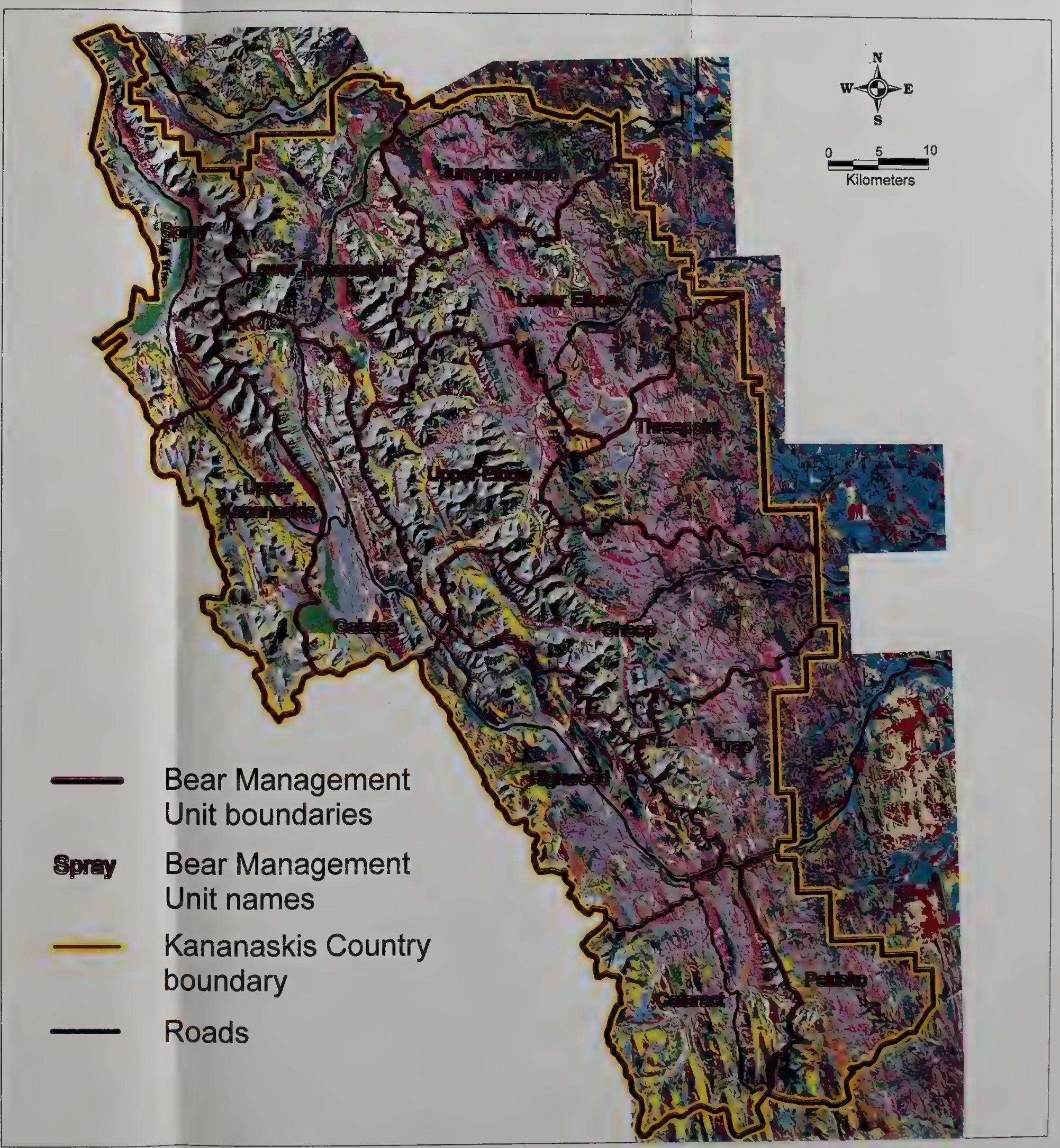

Map C-4. Level 4 land cover classification for Kananaskis Country. 



\section{APPENDIX D: HABITAT SUITABILITY ASSESSMENT TABLES}



Table D-1. Frequency distribution of Level 1 sampling plots by Level 4 habitat map unit.

\section{Level 4 hab. map unit Samples}

\begin{tabular}{lc}
\hline \hline A1.1 & 3 \\
A1.2 & 3 \\
A2. & 1 \\
A2.1 & 13 \\
A2.2 & 13 \\
A2.3 & 18 \\
A3.1/1 & 20 \\
A3.1/2 & 25 \\
A3.1/3 & 19 \\
A3.2/1 & 13 \\
A3.2/2 & 6 \\
A3.2/3 & 7 \\
A3.3/1 & 13 \\
A3.3/2 & 12 \\
A3.3/3 & 13 \\
A4 & 15 \\
B1 & 4 \\
FLV & 18 \\
FM & 21 \\
HM & 2 \\
LP & 6 \\
PB & 5 \\
UDC1/1 & 1 \\
UFC1/1 & 50 \\
UFC1/2 & 47 \\
UFC1/3 & 11 \\
UFC1/4 & 24 \\
UFC1/5 & 62 \\
UFC1/6 & 15 \\
UFC1/7 & 31 \\
UFC1/8 & 57 \\
UFC1/9 & 9 \\
UFC2/1 & 53 \\
UFC2/2 & 30 \\
UFC2/3 & 14 \\
UFC2/4 & 10 \\
UFC2/5 & 8 \\
&
\end{tabular}

Level 4 hab. map unit Samples

\begin{tabular}{ll}
\hline UFC $2 / 6$ & 17 \\
UFC $2 / 7$ & 24 \\
UFC $2 / 8$ & 30 \\
UFC $2 / 9$ & 24
\end{tabular}

UFC $3 / 1$

UFC3/2

UFC $3 / 3$

UFC3/4

UFC $3 / 5$

UFC $3 / 6$

UFC3/7

UFC $3 / 8$

UFC3/9

UFC4/1

UFC $4 / 2$

UFC $4 / 3$

UFC5

UFC6/1

UFC6/3

UFD $1 / 1$

UFD $1 / 2$

UFD1/3

UFD $1 / 4$

UFD $1 / 5$

UFD1/6

UFD2/1

UFD $2 / 2$

UFD $2 / 3$

UFD2/5

UFD4/1

UFM1/1

UFM $1 / 2$

UFM $1 / 3$

UFM $2 / 1$

UFM $2 / 2$

UFM $2 / 3$

UFM $2 / 4$
1

4

3

2

8

2

1

12

6

14

5

6

9

5

6

35

7

27

11

18

3

22

4

4

2

1

26

15

13

16

3

5

1

\section{Level 4 hab. map unit Samples}

\begin{tabular}{lc}
\hline \hline UFM2/5 & 7 \\
UFM2/6 & 3 \\
UFM3/1 & 27 \\
UFM3/2 & 2 \\
UFM3/3 & 2 \\
UFM3/5 & 8 \\
UFM3/6 & 4 \\
UHF & 3 \\
UHG1/1 & 40 \\
UHG1/2 & 15 \\
UHG1/3 & 4 \\
UHG2/1 & 15 \\
UHG2/2 & 47 \\
UHG2/3 & 24 \\
UHG3/1 & 14 \\
UHG3/2 & 16 \\
UHG $3 / 3$ & 9
\end{tabular}

UHG $3 / 3$

USL1

USL2

USL3

USM1

USM2

USM3

USM4

USM5

USM6

USS2

USS3

USS4

USS5

USS6

W1.1/1

W1.1/2

W1.2/1

W1.2/2

W1.3/1

W1.3/2 



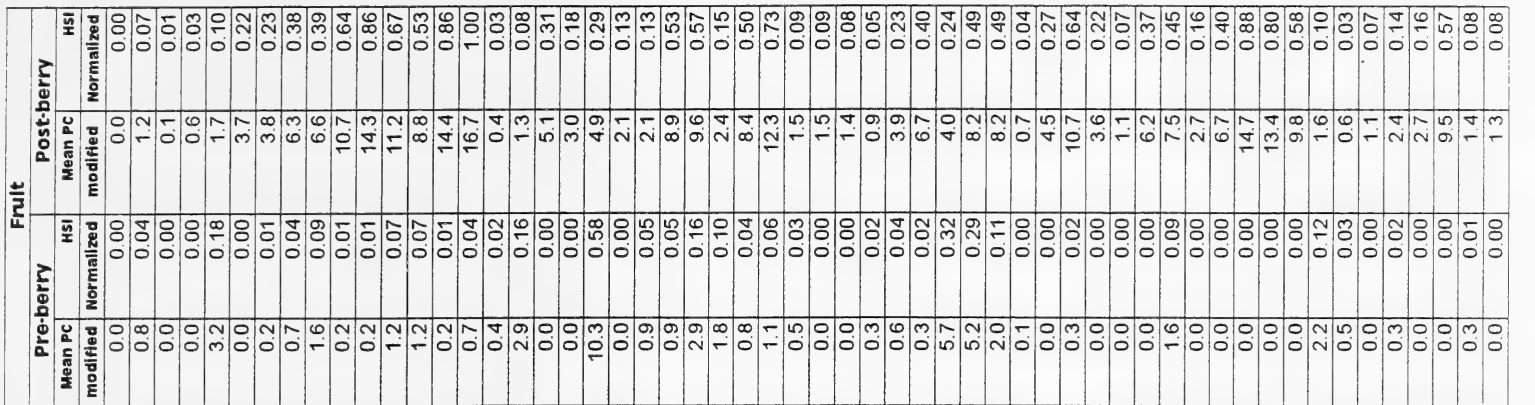

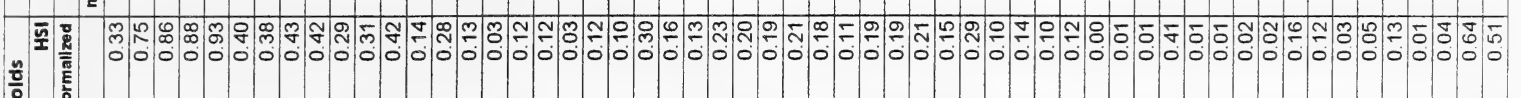

힐

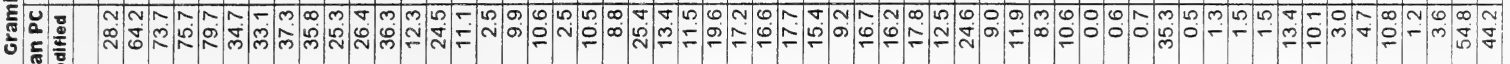

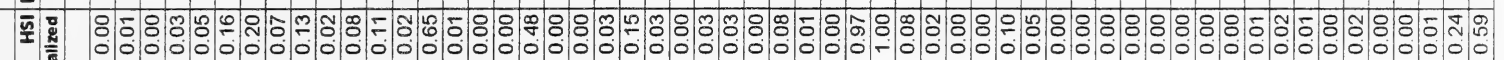

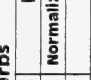

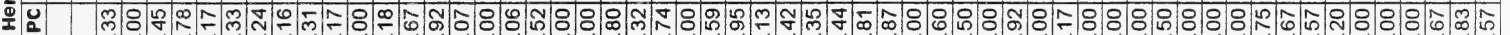

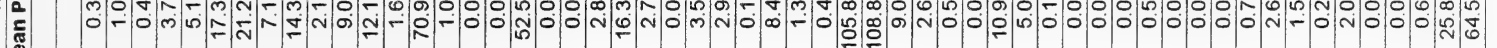

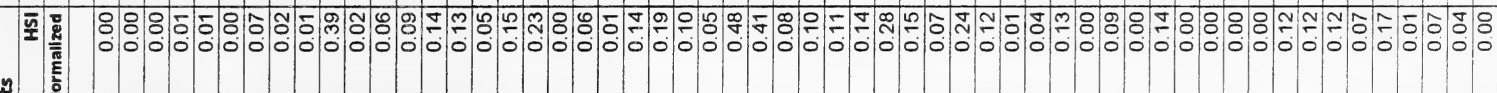

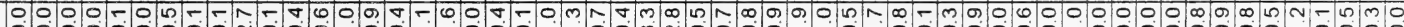

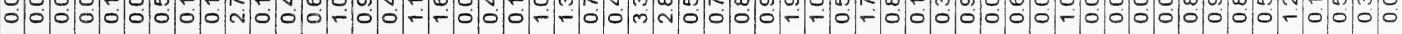

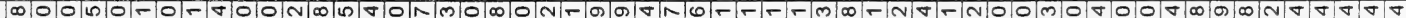

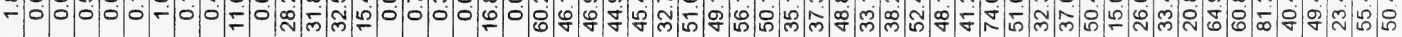

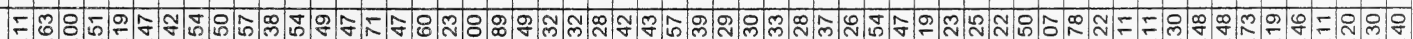

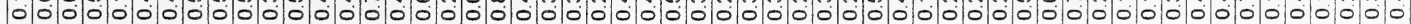

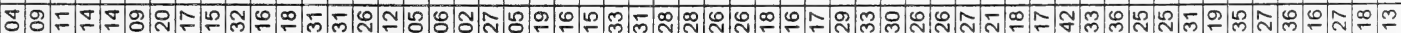

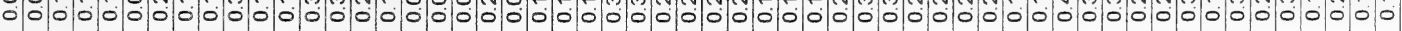

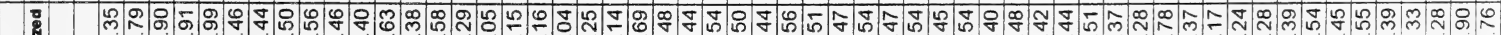

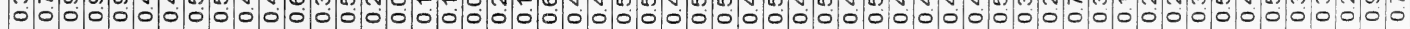

שூ্লন

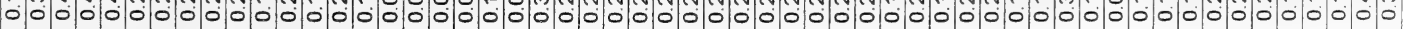

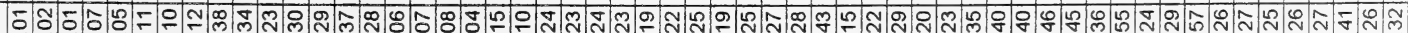

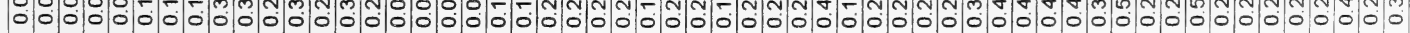

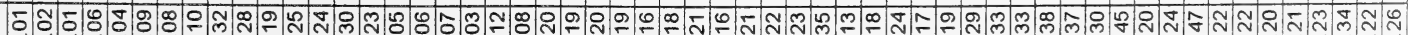

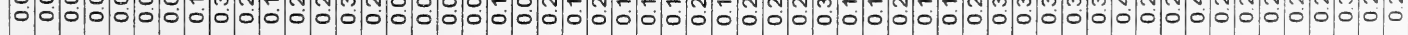





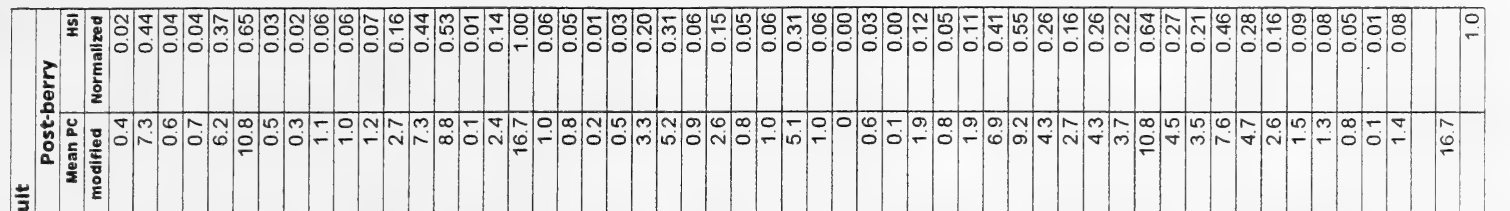

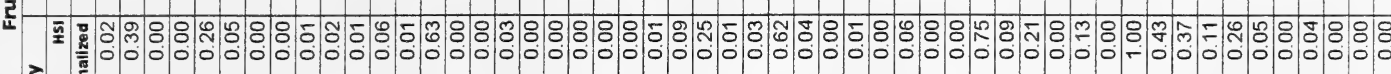

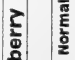

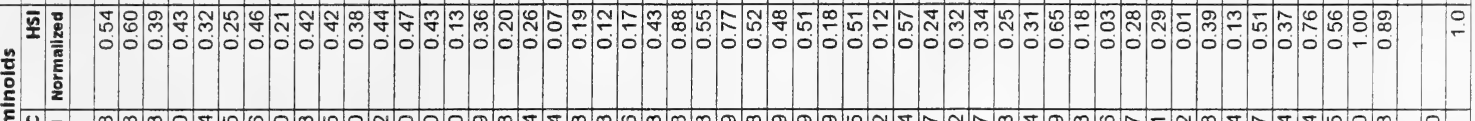

ஏங்

ธี่

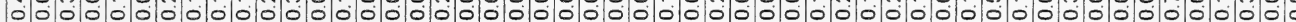

.

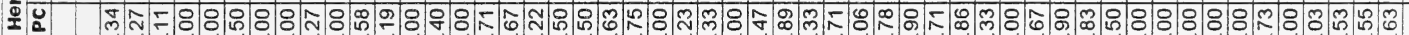

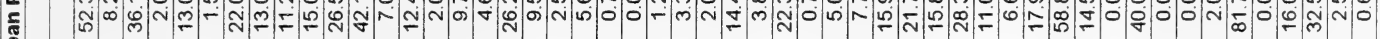

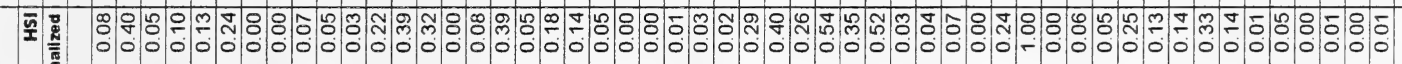

:

:

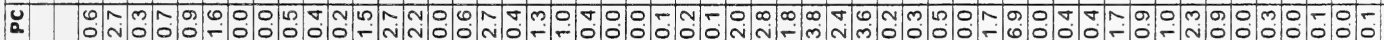

这

m 0 0 00 J

ڤं

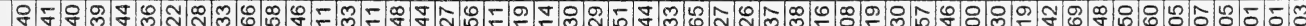

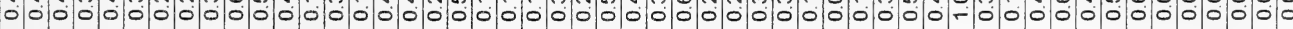

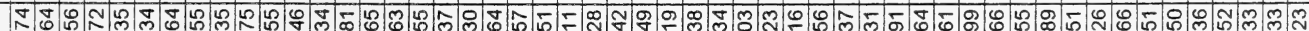

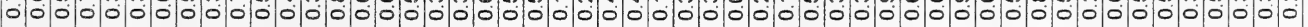

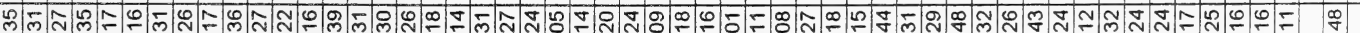

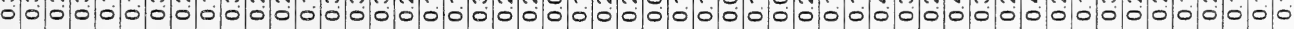

m.

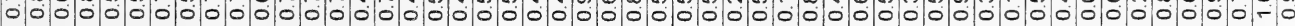

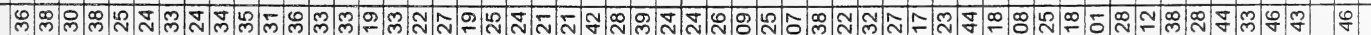

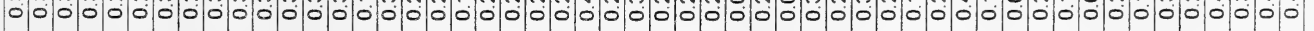

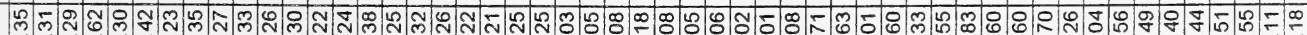

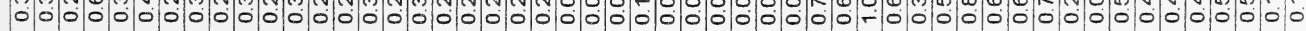

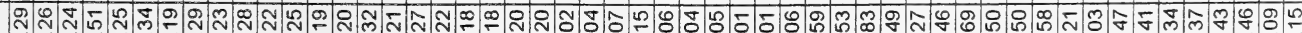

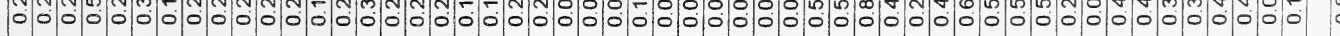

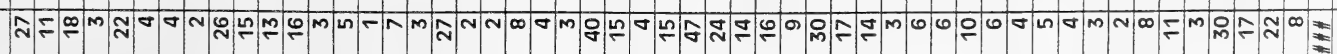



Table D-3. Eastern slopes grizzly bear habitat suitability model output.

\section{Unsorted}

Pre-berry N 离 Raw Normalized*10 Raw Normalized*10 125-cm

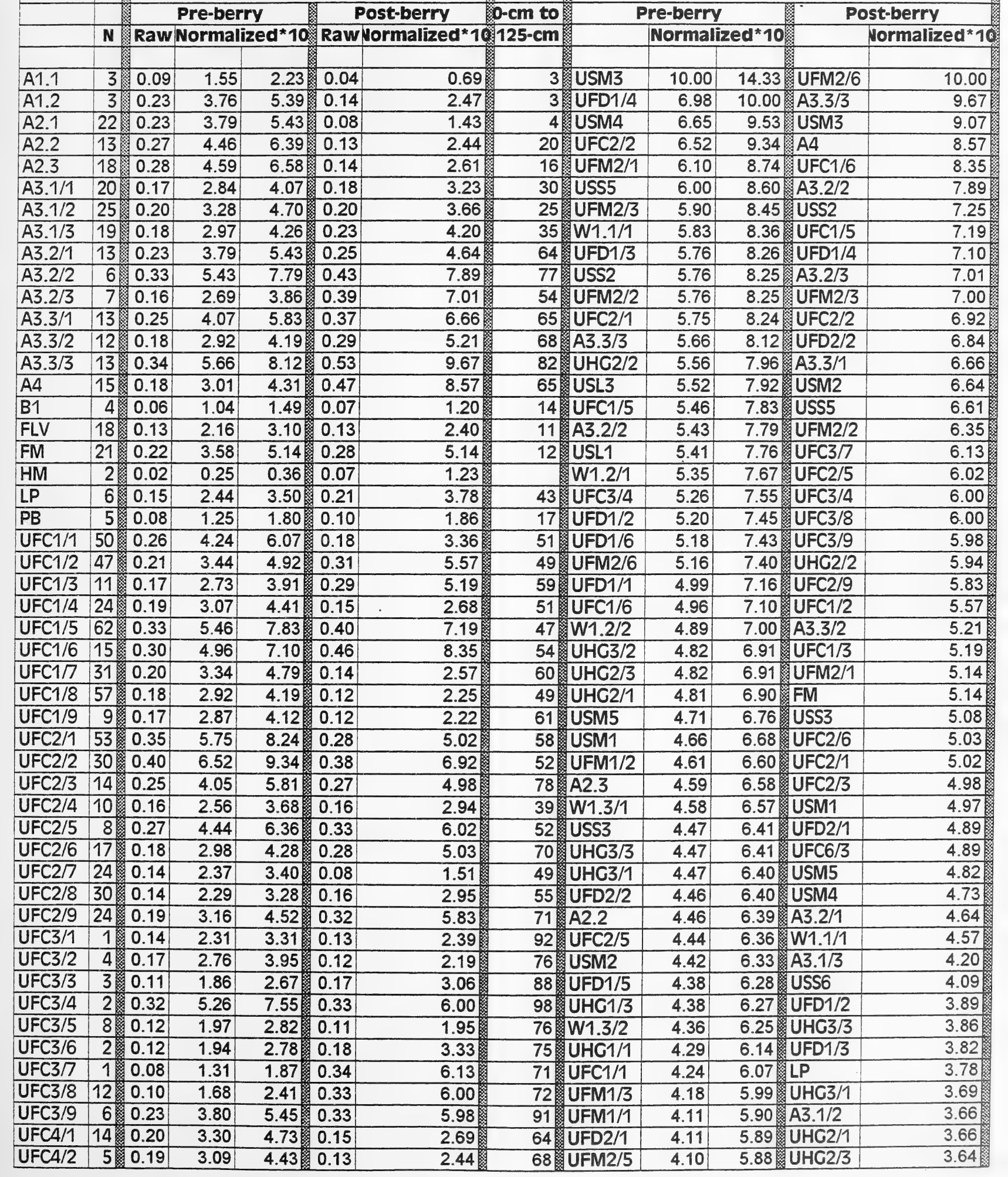

\section{Sorted}

Pre-berry Post-berry Normalized ${ }^{*} 10$ Normalized ${ }^{*} 16$ 

Table D-3. Eastern slopes grizzly bear habitat suitability model output.

Unsorted

HC

Sorted

N $\begin{gathered}\text { Pre-berry } \\ \text { Raw Normalized*10 }\end{gathered}$

$\begin{array}{lc}\text { Pre-berry } & \text { Post-berry } \\ \text { Normalized*10 } & \text { Normalized*16 }\end{array}$

\begin{tabular}{l} 
UFC4/3 \\
\hline UFC5
\end{tabular}

UFC6/1

UFC6/3

UFD1/1 35

UFD $1 / 2 \quad 7 / 0.32$

UFD1/3 $27 \times 0.35$

$\begin{array}{ll:l} & \text { UFD1/4 } & 11 / 0.42\end{array}$

UFD1/5 18 : 0.27

UFD1/6 $3 / 0.31$

UFD2/1 $22 / 0.25$

UFD $2 / 2 \quad 4 / 0.27$

UFD 2/3 4 \% 0.23

UFD $2 / 5 \quad 2 / 0.18$

UFM $1 / 1 / 26 / 0.25$

UFM1/2 $15 / 0.28$

UFM $1 / 3 \quad 13: 0.25$

$\begin{array}{lll:l} & \text { UFM } 2 / 1 & 16 & 0.37\end{array}$

UFM $2 / 2 \quad 3 / 0.35$

UFM $2 / 3 \quad 5 / 0.36$

UFM2/4 $1 / 0.14$

\begin{tabular}{l|l}
\hline UFM2/5 & 7 OM 0.25 \\
\hline
\end{tabular}

UFM2/6 3 橧 0.31

\begin{tabular}{ll|l}
\hline UFM3/1 27 & \\
\hline
\end{tabular}

UFM3/2 2 0.20

UFM3/3 2 / 0.20

UFM3/5 $8 / 0.16$

\begin{tabular}{ll|l}
\hline UFM3/6 & $4 / 0.13$
\end{tabular}

UHF

\begin{tabular}{lll}
\hline UHC1/1 40 \\
\hline
\end{tabular}

$\mathrm{UHG} 1 / 215$

$\mathrm{UHC1/3} 4 / \sqrt{4} 0.27$

UHG2/1 150.29

UHC2/2 47

UHC2/3 24

UHC3/1 14 : 0.27

\begin{tabular}{ll|l} 
& $\mathrm{UHC3} / 2$ & $16 / 0.29$
\end{tabular}

\begin{tabular}{ll}
\hline UHC3/3 & $9 \times 0.27$ \\
\hline & 0.27
\end{tabular}

USL1 30 茲 0.33

\begin{tabular}{lll}
\hline USL2 & 17 & 0.23 \\
\hline
\end{tabular}

USL3 14 0.33

$\frac{U S}{U S}$

the

U

\author{
\begin{tabular}{ll}
\hline$U$ \\
\hline$U$ \\
\hline$U$ \\
\hline$U$ \\
\hline$U$ \\
\hline
\end{tabular}
}

US

6 6.61

6.29

$5 \times 0.35$

\begin{tabular}{|r|r|r|}
\hline 2.65 & 3.80 & 0.10 \\
\hline 3.26 & 4.68 & 0.17 \\
\hline 1.63 & 2.33 & 0.10 \\
\hline 2.39 & 3.42 & 0.27 \\
\hline 4.99 & 7.16 & 0.18 \\
\hline 5.20 & 7.45 & 0.21 \\
\hline 5.76 & 8.26 & 0.21 \\
\hline 6.98 & 10.00 & 0.39 \\
\hline
\end{tabular}

$\begin{array}{lll}4.38 & 6.28 \times 0 & 0.16\end{array}$

$\begin{array}{lll}5.18 & 7.43 & 0.16\end{array}$

$\begin{array}{lll}4.11 & 5.89 \text { \% } 0.27\end{array}$

$4.46 \quad 6.40 \times 0.38$

$3.80 \quad 5.44$ 冈 0.12

\begin{tabular}{ll}
2.98 & 4.27 \\
\hline
\end{tabular}

$4.11 \quad 5.90 \times 0.15$

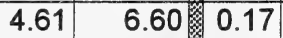

\begin{tabular}{ll}
4.18 & $5.99 \times 0.17$ \\
\hline
\end{tabular}

$\begin{array}{lll}6.10 & 8.74 & 0.28\end{array}$

$\begin{array}{ll}5.76 & 8.25 \\ 0.35\end{array}$

$\begin{array}{ll}5.90 & 8.45 \text { र } 0.38\end{array}$

$\begin{array}{ll}2.35 & 3.37 / 0.06\end{array}$

$\begin{array}{ll}4.10 & 5.88 \text { 冈 } 0.18\end{array}$

$\begin{array}{ll}5.16 & 7.40 \times 0 \\ 0.55\end{array}$

\begin{tabular}{ll}
3.59 & 5.15 \\
\hline & 0.14
\end{tabular}

3.38

3.28

2.71

2.13

2.17

4.29

3.41

4.38

4.81

5.56

4.82

4.47

4.82

4.47

4.85 齐 0.16

$4 . 7 1 \longdiv { 0 . 1 0 }$

$3.89 \times 0.09$

$3.05 \times 0.12$

$3.10 \times 0.17$

$6 . 1 4 \longdiv { 0 . 1 2 }$

4.890 .16

6.270 .13

6.90 媌 0.20

7.960 .33

6.91 . 0.20

6.400 .20

6.910 .20

6.41 范 0.21

$5.41 \quad 7.76$ 堐 0.17

$3.86 \quad 5.54$ 䒽 0.12

5.52

$7.92 \times 0.19$

$\begin{array}{lll}4.66 & 6.68 & 0.27\end{array}$

$4.42 \quad 6.33$ 齐 0.36

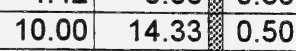

6.65

9.53

0.26

\begin{tabular}{lll}
\hline 4.71 & 6.76 冈 0.27
\end{tabular}

2.77

3.97

5.76

8.25

0.16

4.47

6.41

2.27 0.15

1.81

3.08

1.77

4.89

3.21

3.89

3.82

7.10

3.00

2.84

4.89

6.84

2.16

1.67

2.64

3.15

3.12

5.14

6.35

7.00

1.01

3.30

10.00

2.54

2.85

1.86

1.61

2.17

3.07

2.26

2.87

2.45

3.66

5.94

3.64

3.69

3.57

3.86

3.17

2.25

3.37

4.97

6.64

9.07

4.73

4.82

2.99

7.25

5.08

2.82

1.59

to

41 A3.3/1
59 UFC2/3
60 USL2
75 UFC3/9
51 UFD2/3
53 A2.1

46 部 $A 3.2 / 1$

47 $A 1.2$

49 UFM3/1

78 解

60 W1.1/2

73 USS6

29 葆 UFC1/2

53 UHG1/2

55 谕 UFM3/2

63 UFC1/7

59 斊 UFC4/1

52 UFM3/3

57 A3.1/2

45 UFC5

82 UFC2/9

65 UFC4/2

79 UFC1/4

53 齐 A4

UFC $2 / 6$

51 UFD2/5

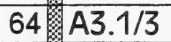

62 齐 $A 3.3 / 2$

2) UFC1/8

12 U. UFC1/9

16 A3.1/1

40 龍 USM6

14 UFC3/2

12 UFC $1 / 3$

15 UFM3/5

$0 . A 3.2 / 3$

2 UFC4/3

13 UFC2/4

83 卤 LP

50 UFC6/3

51 UFC2/7

62 UFM2/4

50 UFC3/1

43 UFC2/8

UHF

69 离 FLV

84 UFM3/6

67 UFC3/5

37 UFC3/6

2 UFC3/3
$4.07 \quad 5.83$ UHG3/2

4.055 .81 USL3

$3.86 \quad 5.54$ UFC1/1

$3.80 \quad 5.45$ UFC3/6

$3.80 \quad 5.44$ 济UFM2/5

$3.79 \quad 5.43$. A3.1/1

3.795 .43 UFD1/1

$3.76 \quad 5.39$ USL1

3.595 .15 UFM1/2

$3.58 \quad 5.14$ UFM1/3

$3.53 \quad 5.06$ UFC5

$3.51 \quad 5.04$ UHF

$3.44 \quad 4.92$ UFC3/3

3.414 .89 UFD1/5

3.384 .85 USM6

$3.34 \quad 4.79$ UFC2/8

$3.30 \quad 4.73$ UFC2/4

3.28 4.71 UHG1/2

3.284 .70 UFM3/2

3.264 .68 UFD1/6

3.16 4.52 USS4

3.09 4.43 $\mathrm{W} 1.2 / 1$

$3.07 \quad 4.41$ UFC4/1

3.014 .31 UFC1/4

2.984 .28 W1.2/2

2.984 .27 UFM1/1

$2.97 \quad 4.26$ A2.3

2.924 .19 U UFC1/7

2.92

2.87

4.19商UFM3/1

4.12 $\mathrm{A} 1.2$

2.844 .07 UHG1/3

2.773 .97 缁 UFCA/2

2.76

3.95 A2.2

2.733 .91 緕 $\mathrm{FL}$

$2.71 \quad 3.89$ 织UC3/1

2.693 .86 UHG1/1

2.653 .80 UFC1/8

2.563 .68 USL2

2.443 .50 谣 UFC1/9

2.393 .42 UFC3/2

2.373 .40 W1.3/2

$2.35 \quad 3.37$ UFM3/6

2.313 .31 थ UFD $2 / 3$

2.293 .28 的1.1/2

2.173 .10 U UFC3/5

2.163 .10 UFM3/3

2.133 .05 齐 PB

1.972 .82 UFC4/3

1.942 .78 UFC6/1

1.86

2.67

W1.3/1

3.57

3.37 

Grizzly Bear Status in K-Country - ESGBP 90

Table D-3. Eastern slopes grizzly bear habitat suitability model output.

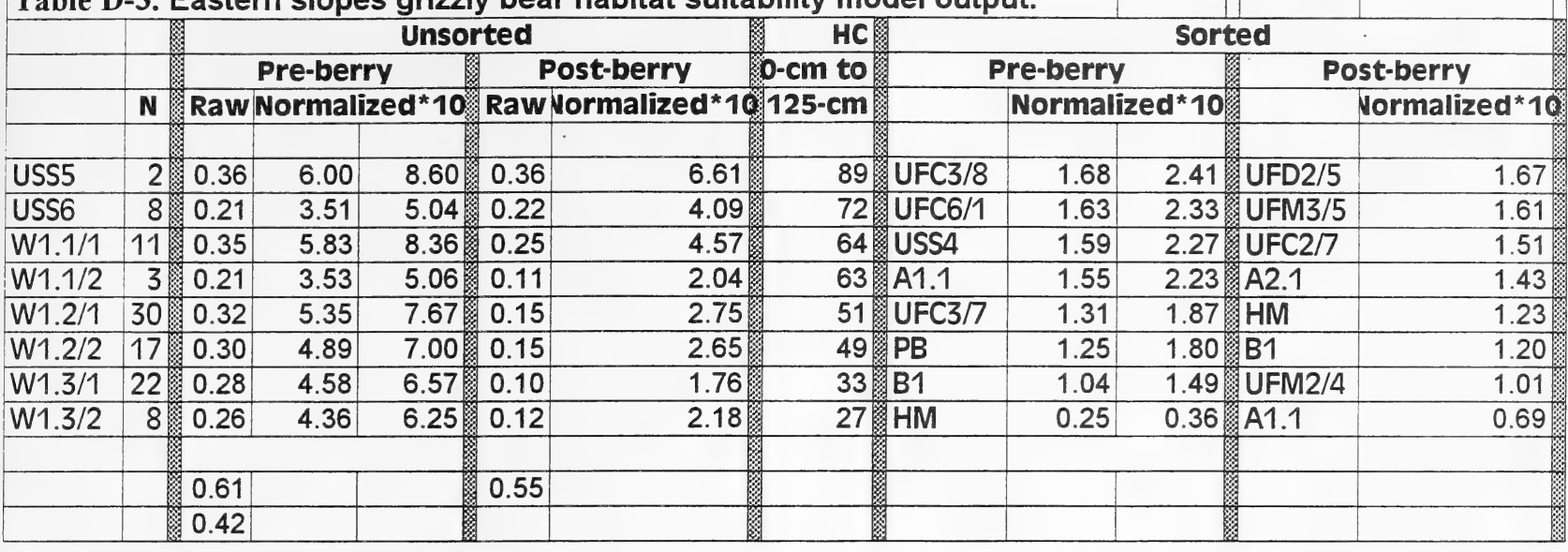



APPENDIX E: POTENTIAL AND REALIZED HABITAT SUITABILITY MAPS BY BEAR MANAGEMENT UNIT (BMU) 


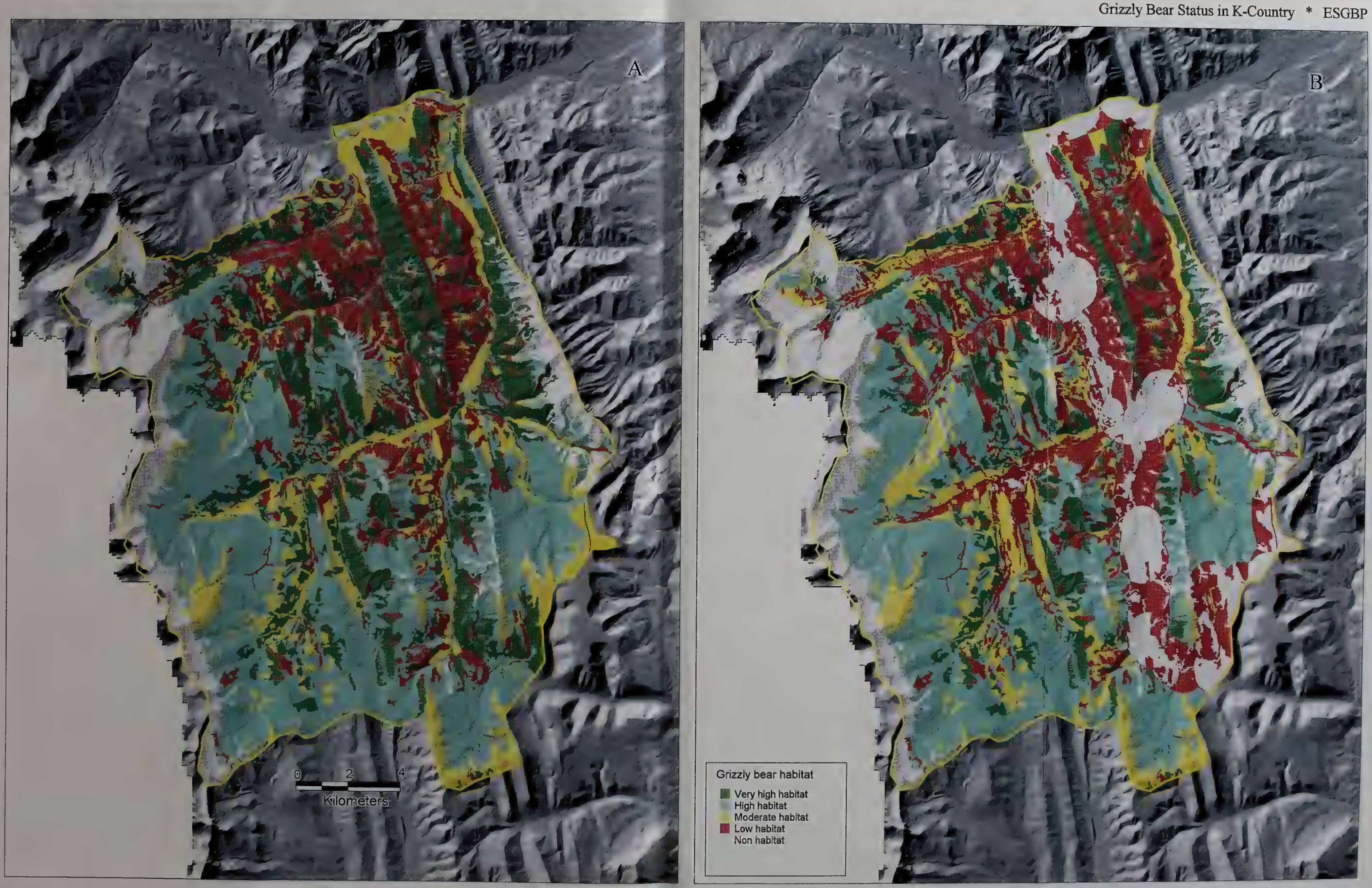

Map E-1. Potential (A) and realized (B) habitat suitability: Cataract Bear Management Unit. 


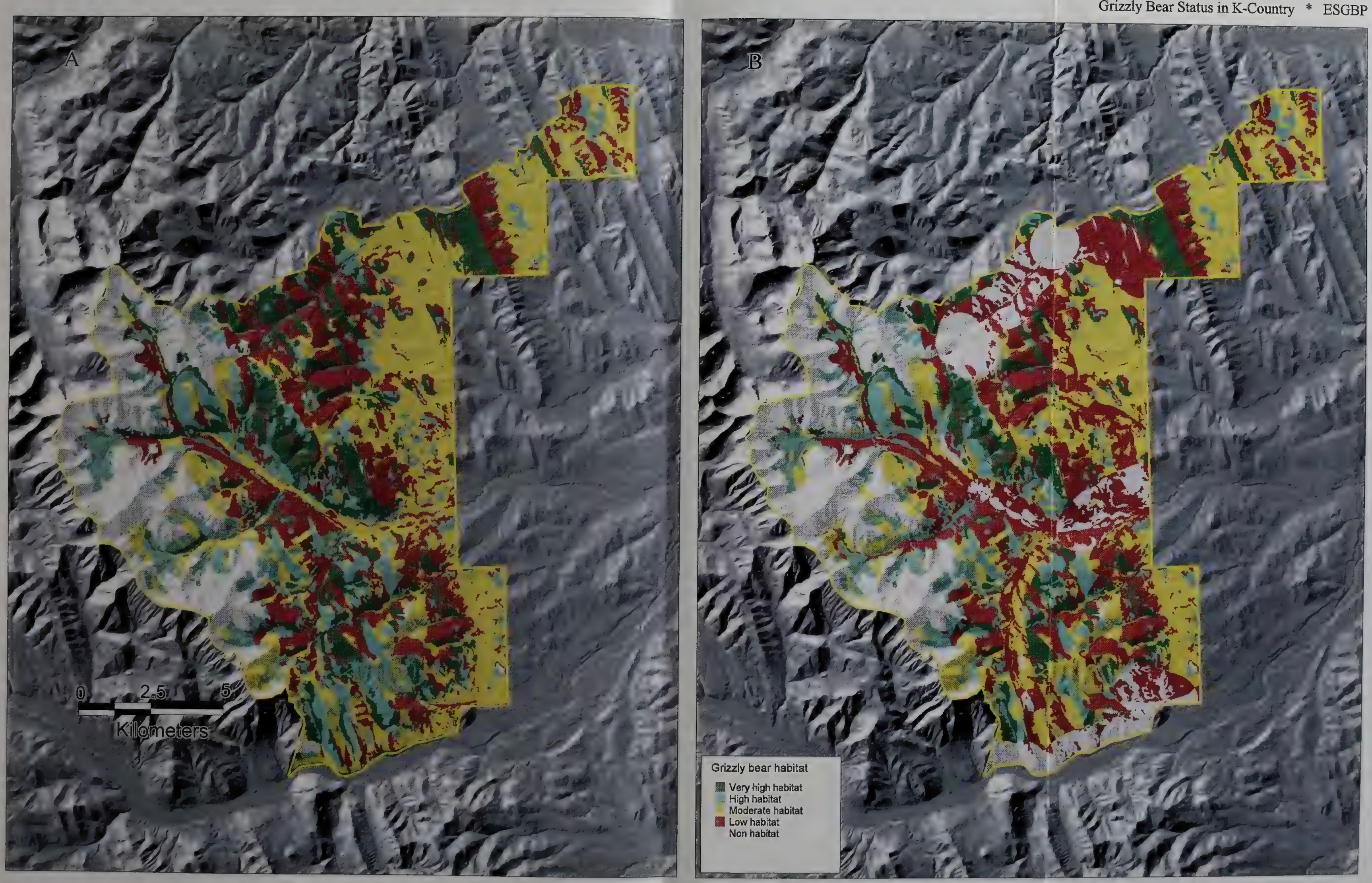

Map E-2. Potential (A) and realized (B) habitat suitability: Trap Bear Management Unit. 


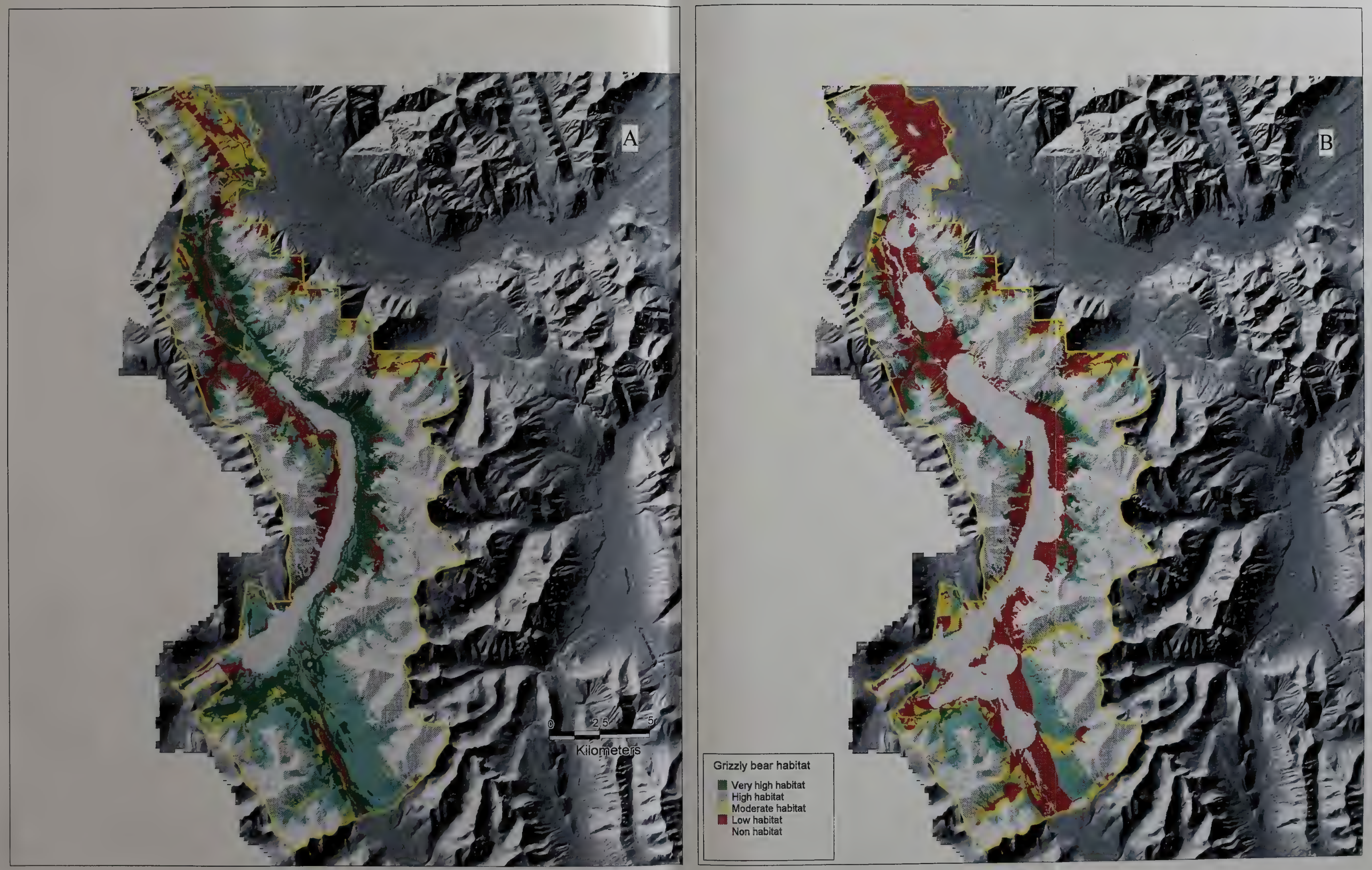

Map E-3. Potential (A) and realized (B) habitat suitability: Spray Bear Management Unit. 


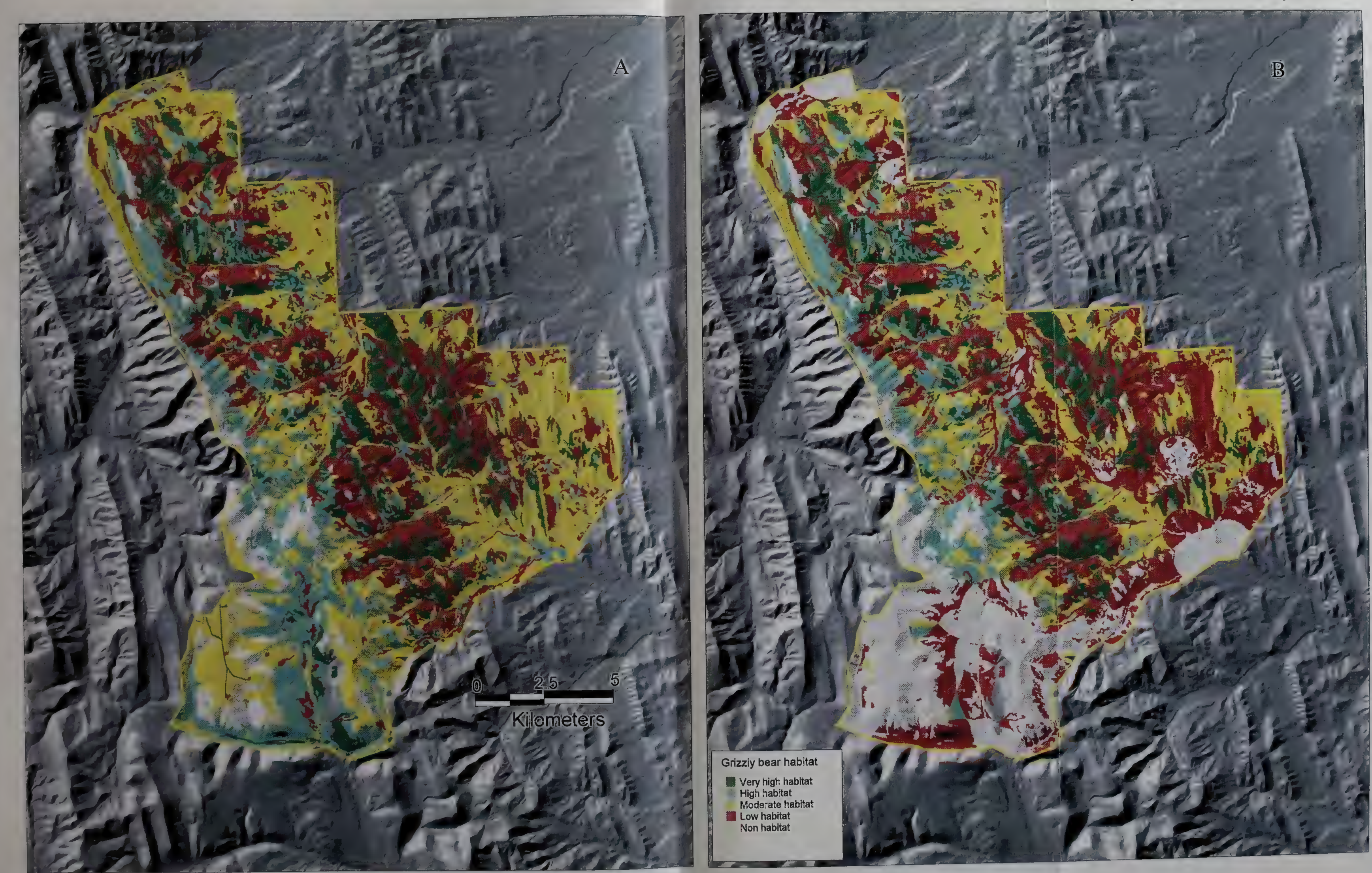

Map E-4. Potential (A) and realized (B) habitat suitability: Pekisko Bear Management Unit. 


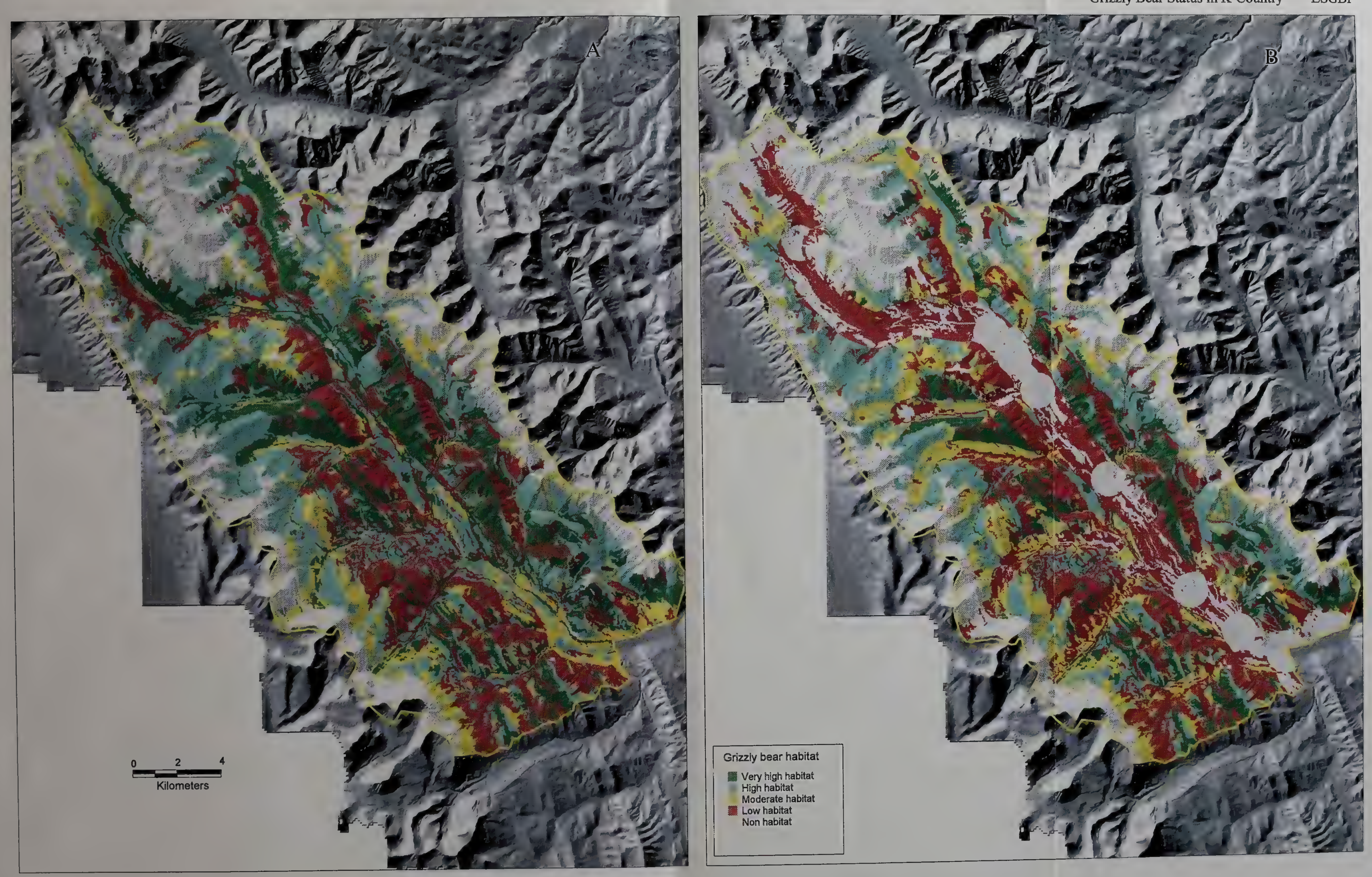

Map E-5. Potential (A) and realized (B) habitat suitability: Highwood Bear Management Unit. 


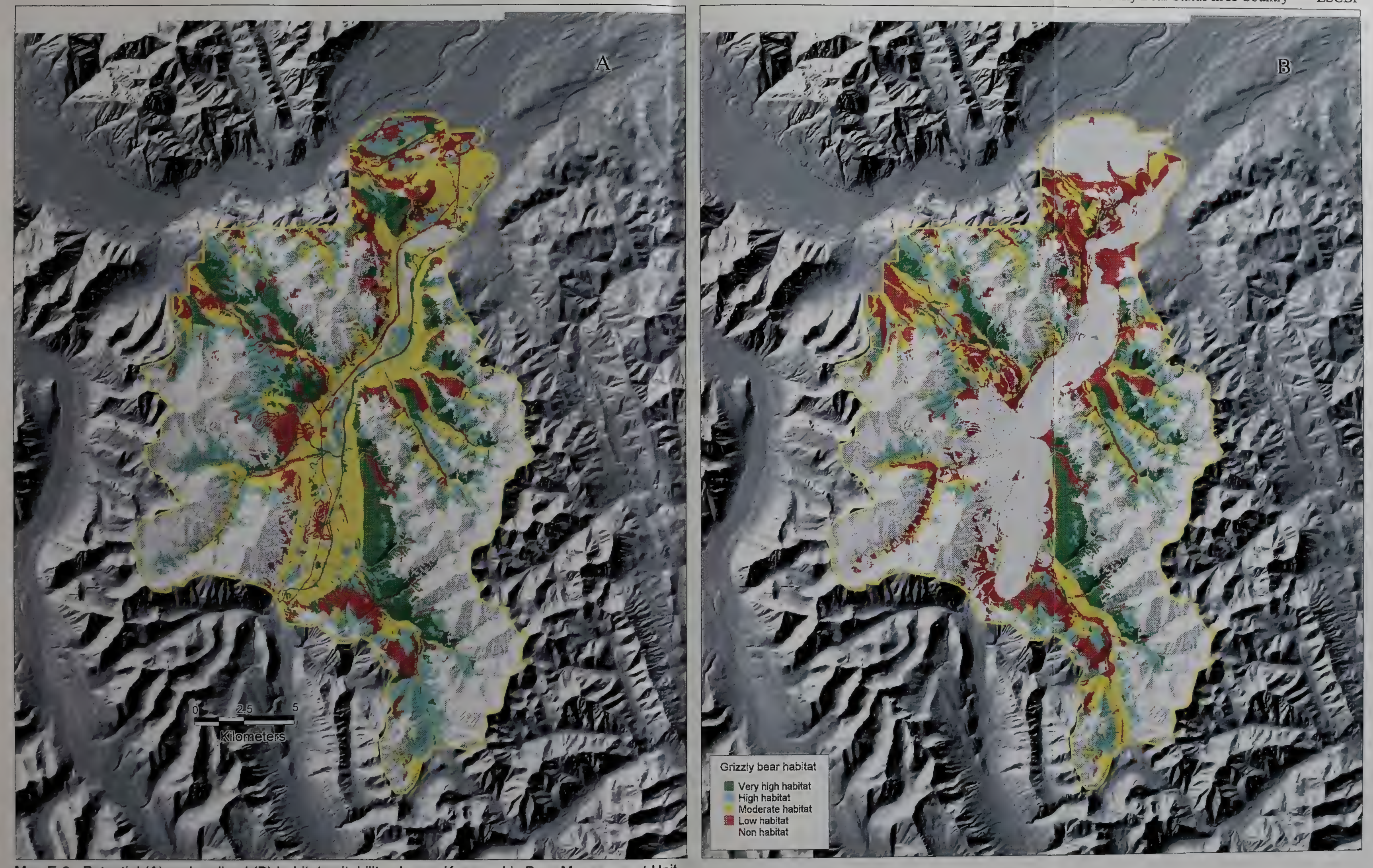

Map E-6. Potential (A) and realized (B) habitat suitability: Lower Kananaskis Bear Management Unit. 


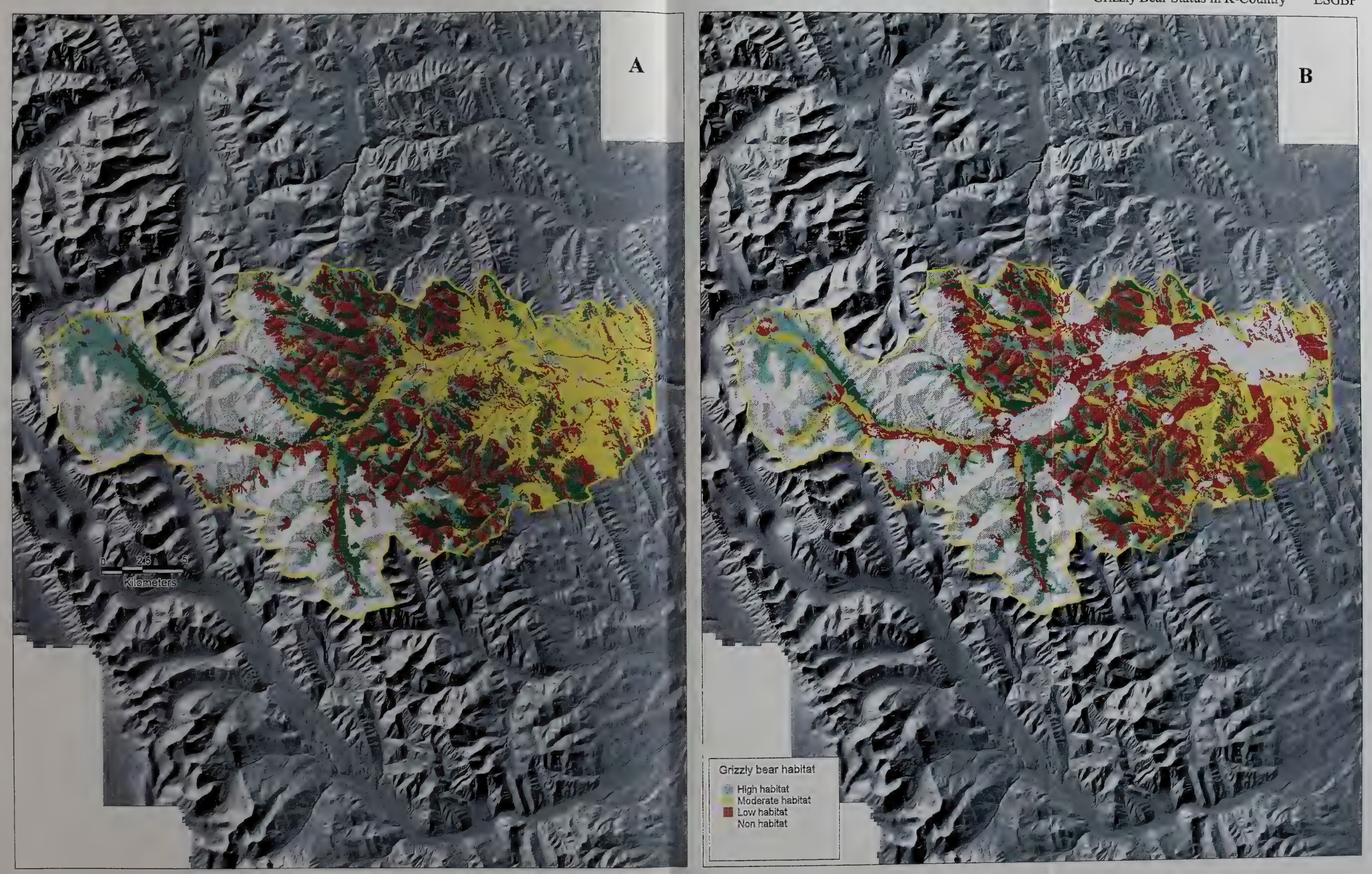

Map E-7. Potential (A) and realized (B) habitat suitability: Sheep Bear Management Unit. 


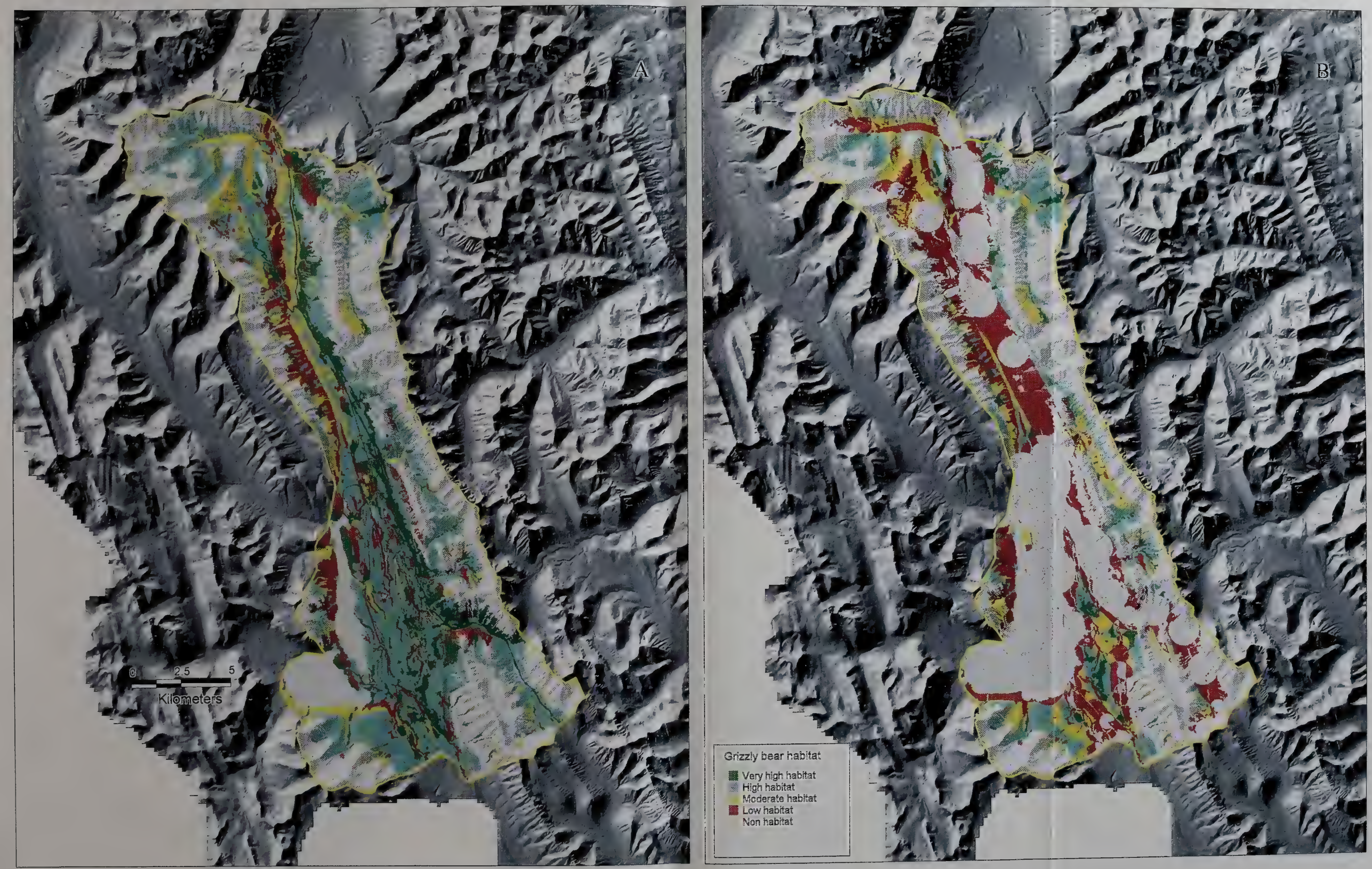

Map E-8. Potential (A) and realized (B) habitat suitability: Galatea Bear Management Unit. 


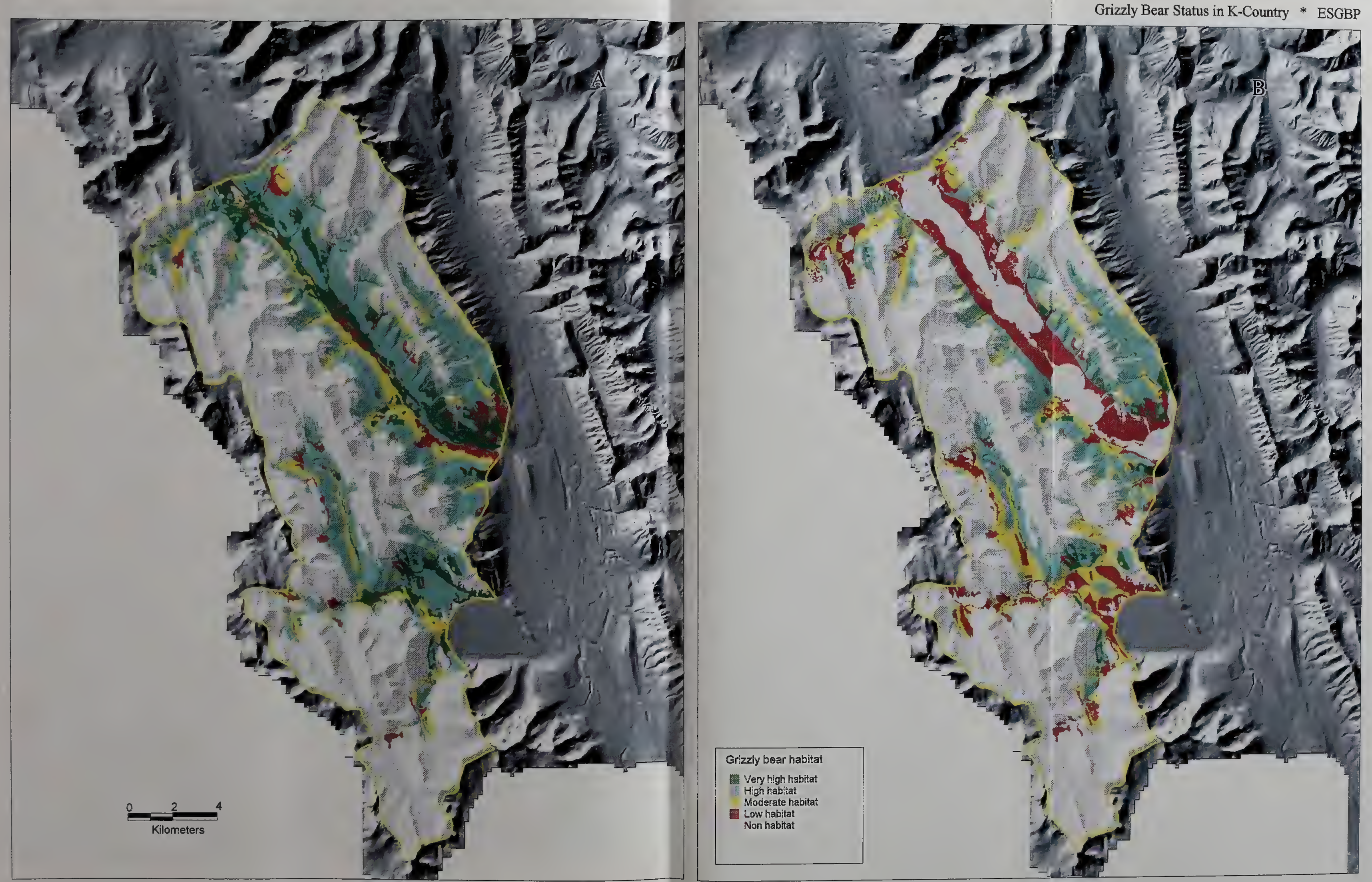

Map E-9. Potential (A) and realized (B) habitat suitability: Upper Kananaskis Bear Management Unit. 


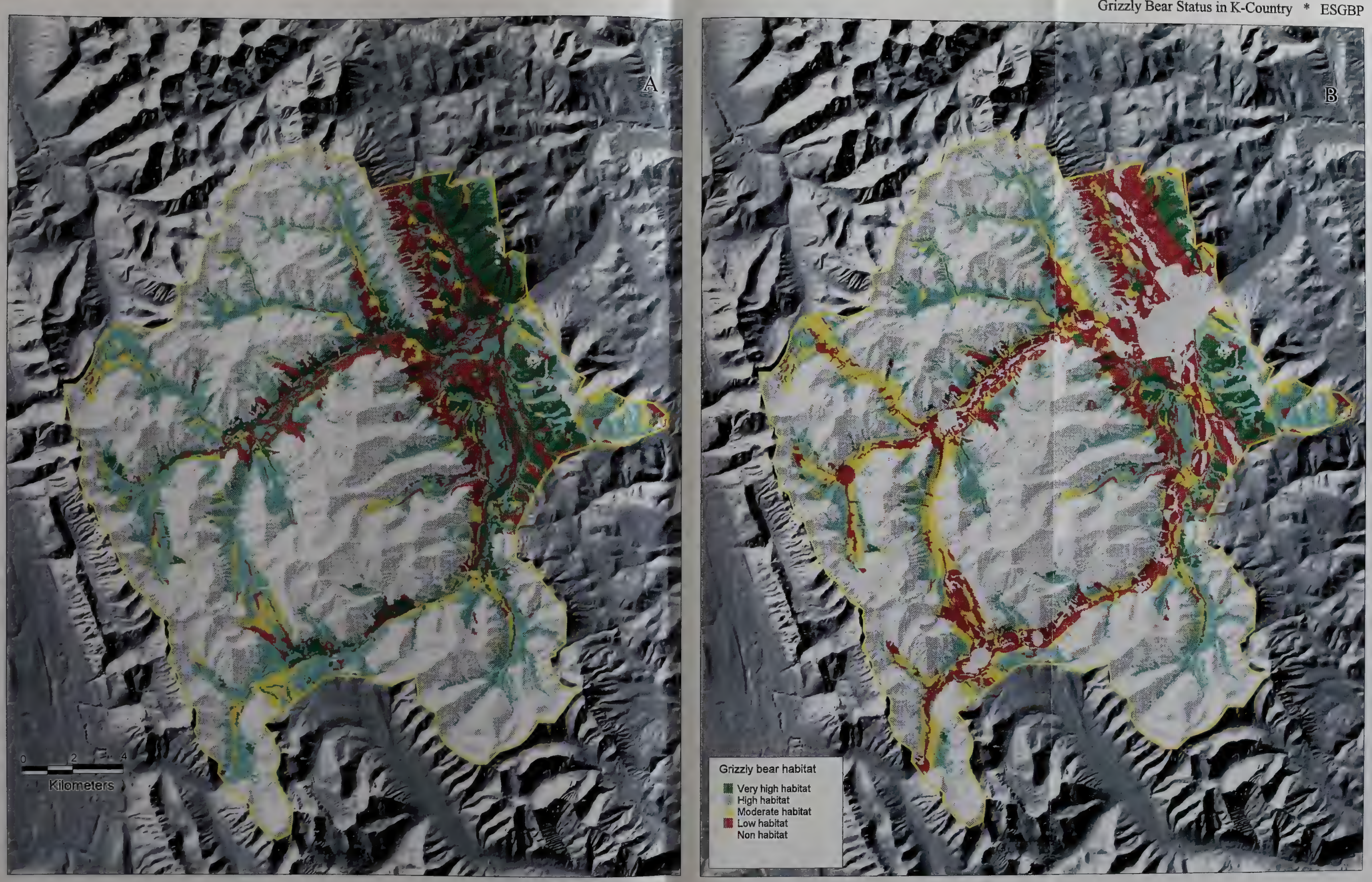

Map E-10. Potential (A) and realized (B) habitat suitability: Upper Elbow Bear Management Unit. 


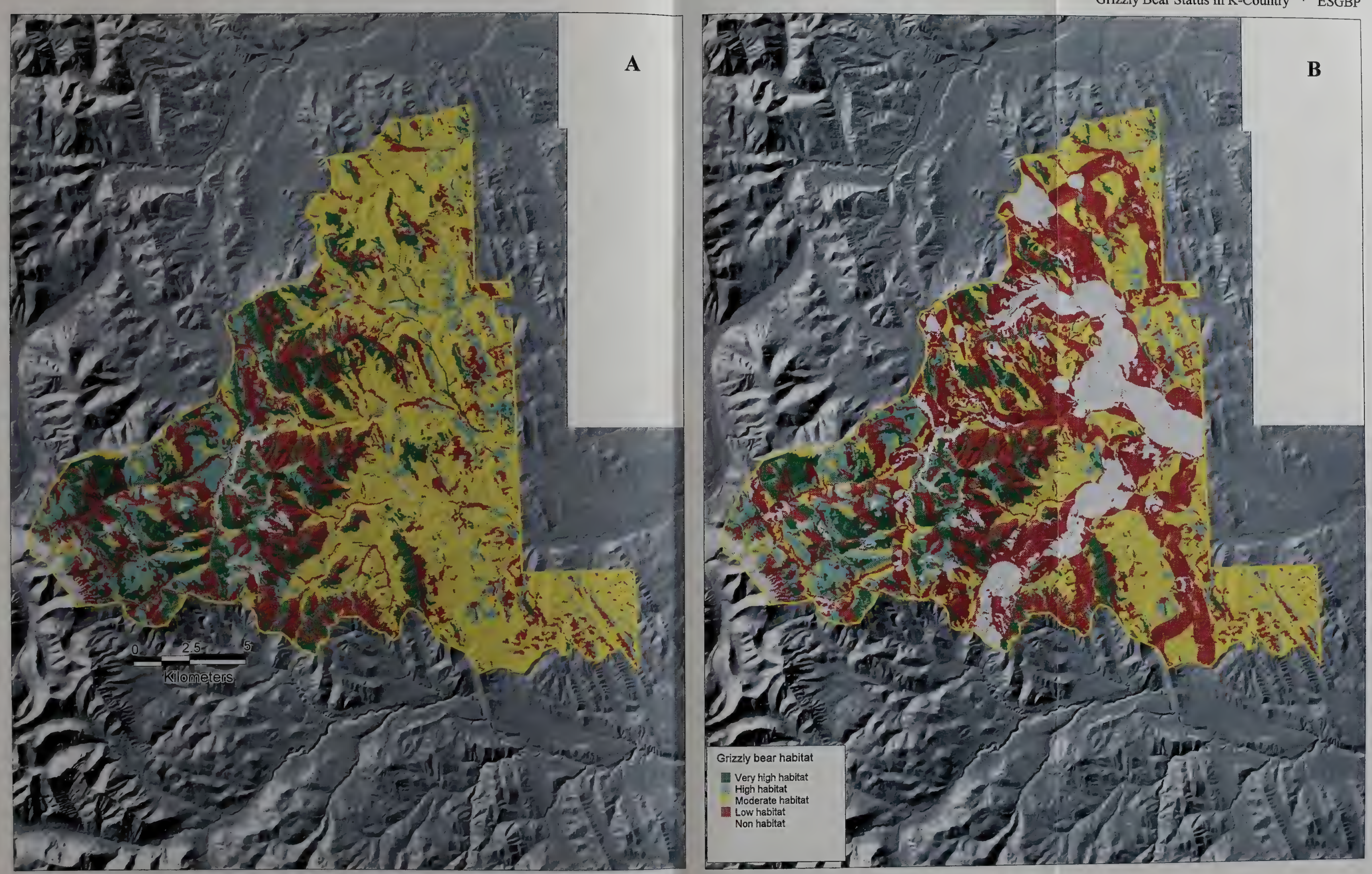

Map E-11. Potential (A) and realized (B) habitat suitability: Threepoint Bear Management Unit. 


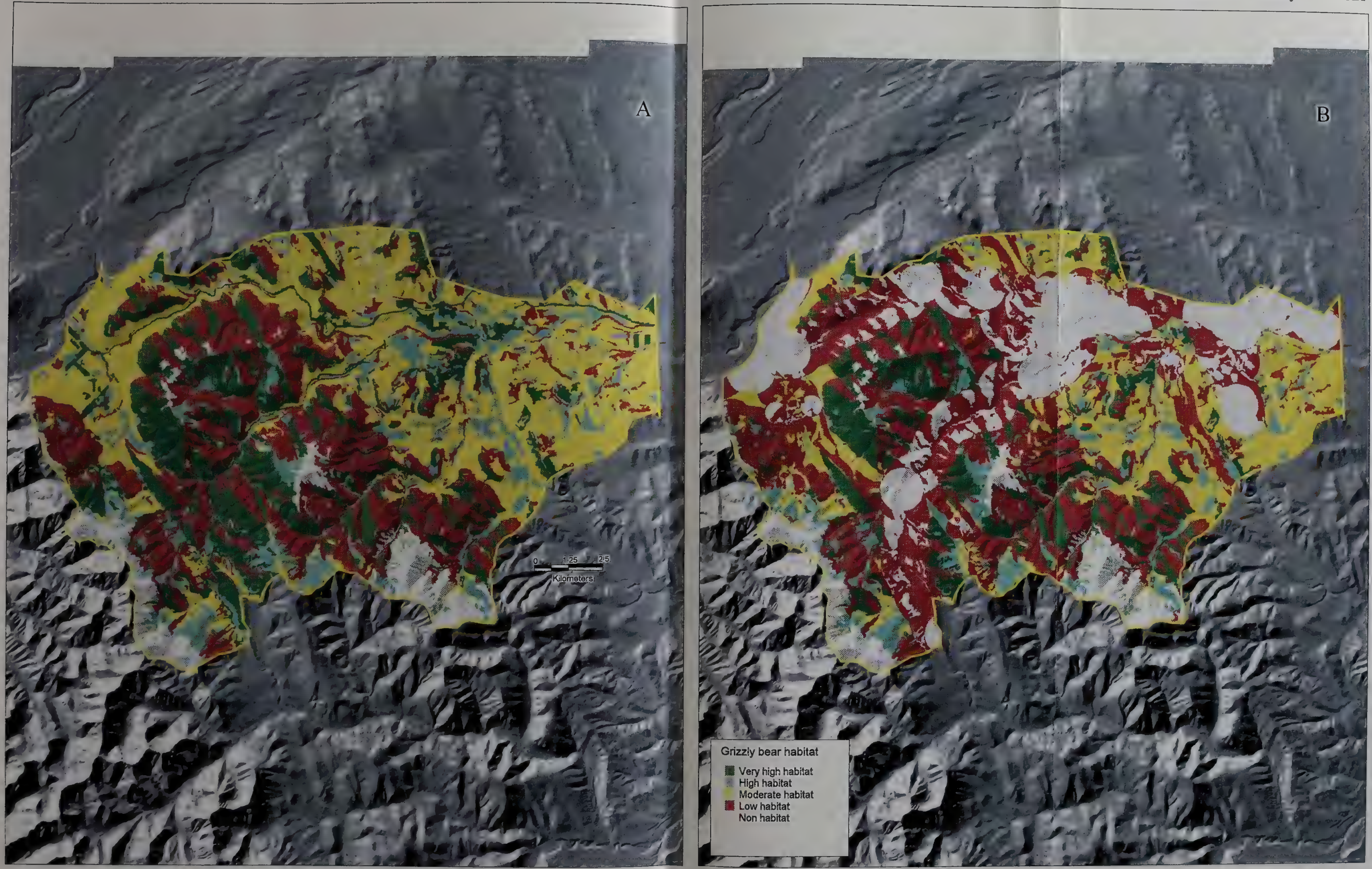

Map E-12. Potential (A) and realized (B) habitat suitability: Jumpingpound Bear Management Unit. 

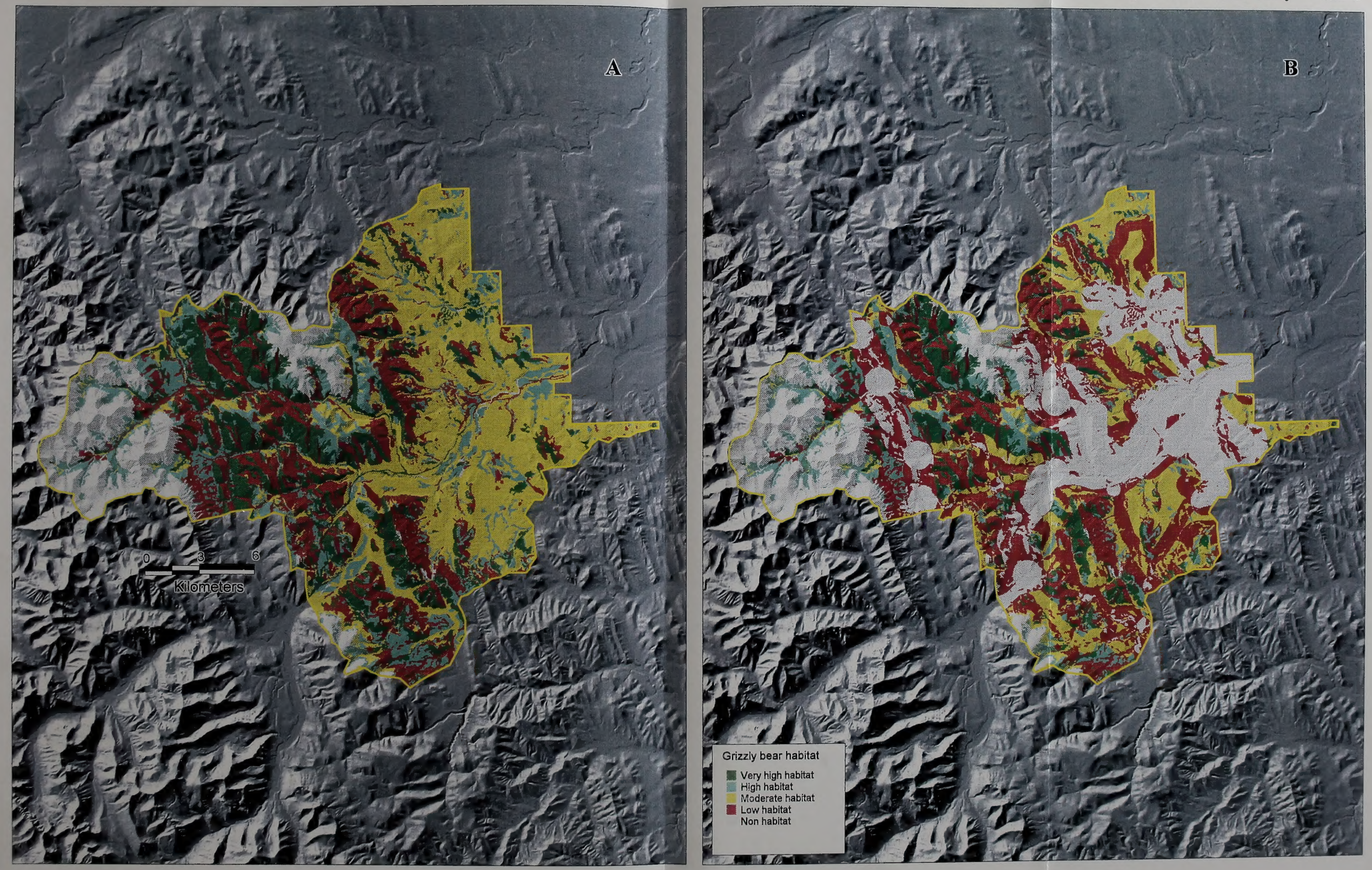

Map E-13. Potential (A) and realized (B) habitat suitability: Lower Elbow Bear Management Unit. 


National Library of Canada
Bibliotheque nationale du Canada

3 3286516834971 